\title{
8. SITE 453: WEST SIDE OF THE MARIANA TROUGH ${ }^{1}$
}

\author{
Shipboard Scientific Party²
}

\section{HOLE 453}

Date occupied: 28 March 1978

Date departed: 4 April 1978

Time on hole: 164 hours, 24 minutes ( 6.85 days)

Position: $17^{\circ} 54.42^{\prime} \mathrm{N} ; 143^{\circ} 40.95^{\prime} \mathrm{E}$

Water depth (sea level, corrected m, echo sounding): 4693

Water depth (rig floor, corrected m, echo sounding): 4703

Bottom felt at: 4703 meters, drill pipe

Penetration (m): 605

Number of holes: 1

Number of cores: 64

Total length of cored section (m): 605

Total core recovered $(\mathrm{m}): 236.83$

Percentage core recovery: 39.1

Oldest sediment cored:

Depth sub-bottom (m): 446

Nature: Sandy vitric tuff (epiclastic)

Chronostratigraphic unit: Earliest Pliocene

Measured velocity $(\mathrm{km} / \mathrm{s}): 2.29$

Basement:

Depth sub-bottom (m): 455.5

Nature: Variably altered polymict igneous breccias above intensely sheared gabbro cataclastites. Not considered "true" basement.

Velocity range $(\mathrm{km} / \mathrm{s}): 3.27-6.82$

Principal results: Site 453 is the westernmost of the three drilling targets in the Mariana Trough (SP4-D), located in a sediment pond about $20 \mathrm{~km}$ long and 3 to $4 \mathrm{~km}$ wide striking approximately $030^{\circ}$. The site is about $10 \mathrm{~km}$ east of the eastern edge of the West Mariana Ridge. A downhole heat flow of $2.4 \mathrm{HFU}$ was obtained on the first use of the Uyeda/Kinoshita heat probe. The hole was not logged because the drill pipe was bent after taking the final core.

The sediment section consists of $\mathbf{4 5 5 . 5}$ meters of muds, silts, and sands composed mainly of volcanic debris. The oldest fossils are early Pliocene from the $T$. rugosus nannofossil subzone. The latter provides a minimum "basement" age of over 4.7-5.0 m.y., which is substantiated by paleomagnetic evidence in the sediments. The sediment age implies a maximum half-spreading rate of 2.7

\footnotetext{
1 Initial Reports of the Deep Sea Drilling Project, Volume 60.

2 Donald M. Hussong (Co-Chief Scientist), Hawaii Institute of Geophysics, Honolulu, Hawaii; Seiya Uyeda (Co-Chief Scientist), Earthquake Research Institute, University of Tokyo, Tokyo, Japan; René Blanchet, Université de Bretagne Occidentale, Brest, France; Ulrich Bleil, Institut für Geophysik, Ruhr Universität, Bochum, Federal Republic of Germany; C. Howard Ellis, Marathon Oil Company, Denver Research Center, Littleton, Colorado; Timothy J. G. Francis, Institute of Oceanographic Sciences, Surrey, United Kingdom; Patricia Fryer, Hawaii Institute of Geophysics, Honolulu, Hawaii; Ki-Iti Horai, LamontDoherty Geological Observatory, Palisades, New York; Stanley Kling. Marine Life Research Group, Scripps Institution of Oceanography, La Jolla, California (present address: 416 Shore View Lane, Leucadia, California); Arend Meijer, Department of Geosciences, University of Arizona, Tucson, Arizona; Kazuaki Nakamura, Earthquake Research Institute, University of Tokyo, Tokyo, Japan; James H. Natland, Deep Sea Drilling Project, Scripps Institution of Oceanography, La Jolla, California; Gordon H. Packham, Department of Geology and Geophysics, University of Sydney, Sydney, N.S.W. Australia; and Anatoly Sharaskin, Vernadsky Institute of Geochemistry, U.S.S.R. Academy of Sciences, Moscow, U.S.S.R.
}

$\mathrm{cm} / \mathrm{y}$. in the Mariana Trough, although other evidence suggests that the spreading is considerably slower and also may have been episodic. Sediment accumulation rates are very high, but decrease with time, and average about $7 \mathrm{~kg} / \mathrm{cm}^{2} / \mathrm{m} . \mathrm{y}$.

Below sediments, 85.5 meters of coarse, poorly sorted igneous polymict breccia containing mainly large angular gabbro and metagabbro clasts up to a half meter in size with minor basalts overlie $\mathbf{2 8 . 5}$ meters of metamorphosed (lower greenschist facies) polymict breccia containing mainly metavolcanic clasts with no large cobbles and rare gabbros. Beneath these are sheared metaigneous rocks, including a continuously recovered 1.5 -meter interval of highly sheared serpentinite noritic gabbro cataclastite cored before the bit wore out. All of these rocks are geochemically related to arc magma series, hence were apparently derived from the West Mariana Ridge. Metamorphism appears hydrothermal in origin in the lower parts of breccias. Seismic evidence suggests that the top of the cored igneous rock, which may be a slump or avalanche sequence over a possible fault zone associated with the initial opening of the Mariana Trough, is flat-lying and on the order of 500 meters above acoustic basement.

\section{BACKGROUND AND OBJECTIVES}

Site 453 (site survey target SP-4F) was planned to sample the oldest back-arc basin crust in the still-active extensional Mariana Trough. Based on its position on the western edge of the basin (about $10 \mathrm{~km}$ east of the western edge of the West Mariana Ridge; Fig. 1), its depth, and its thick sediment cover, SP-4F was predicted to lie on crust that was formed during the initial rifting that produced the Mariana Trough.

The specific objectives of the SP4-F drilling included:

1) determination of the time initiation of the opening of the Mariana Trough through paleontological, paleomagnetic, and radiometric means by penetrating through the sediments and into the igneous basement;

2) petrologic study of the basement rock as representative of the upper marginal basin crust formed during the first stage of back-arc extension; and

3 ) determination of the history of tectonic and volcanic activity in the Trough, and possibly the nearby remnant West Mariana Ridge and the Mariana volcanic arc, since the initial stages of back-arc rifting.

IPOD site selection surveys near SP4-F revealed the following general characteristics of this portion of the western edge of the Mariana Trough (for more details see Fryer and Hussong, this volume):

1) There are no obviously correlatable sea-floorspreading type magnetic anomalies;

2) The topography is very irregular but has some suggestion of predominant block faulting with the blocks tilted to the west so that the eastern sides of many of the topographic highs are fault scarps (Fig. 2).

3) The SP4-F site is about $40 \mathrm{~km}$ north of a broad, east-west trending bathymetric low suggestive of a fracture zone (Fig. 1); 


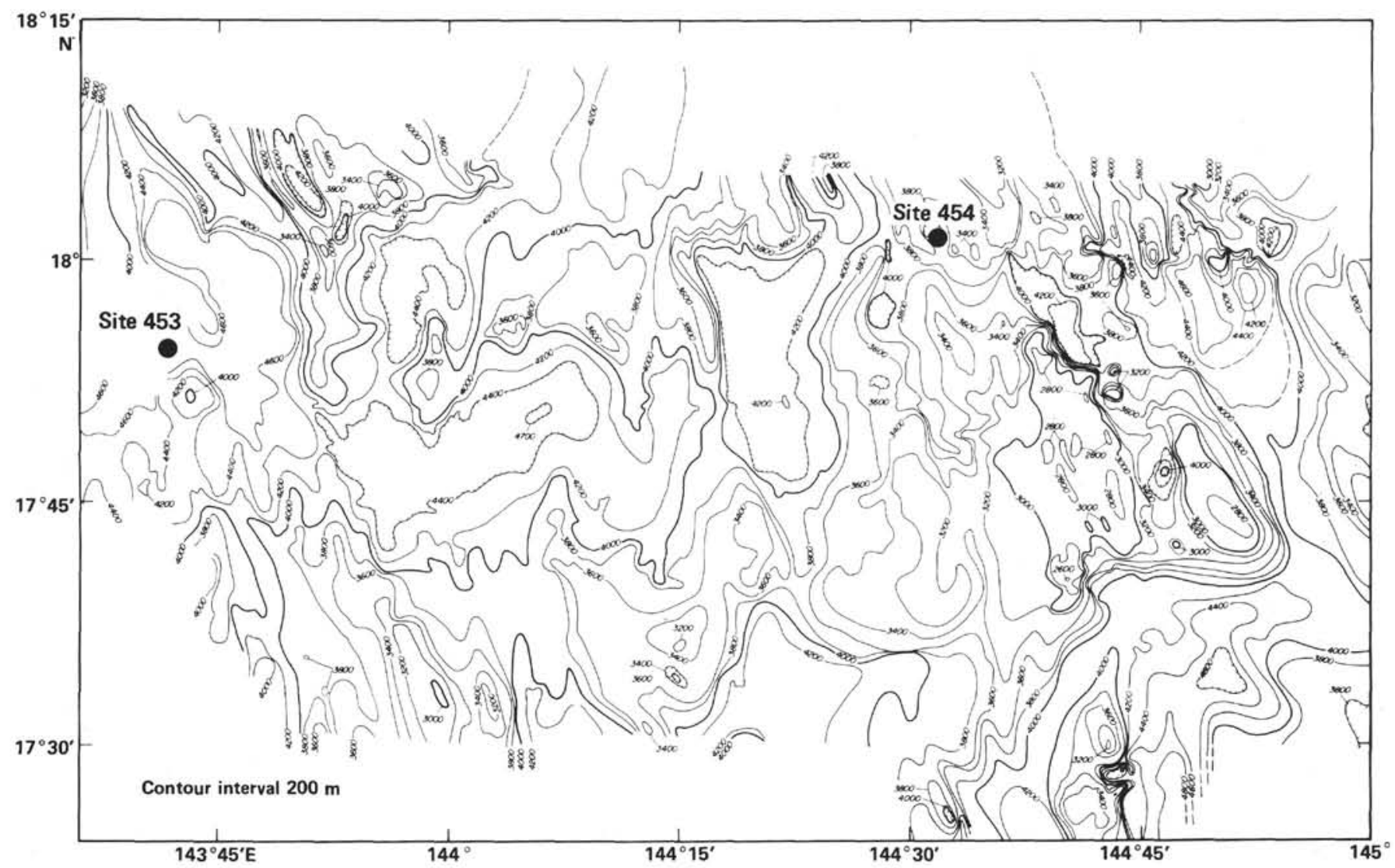

Figure 1. Bathymetry of the Mariana Trough (from Hussong, this volume), in corrected meters at a 200 -meter contour interval. Site 453 is at the western edge of the Trough.

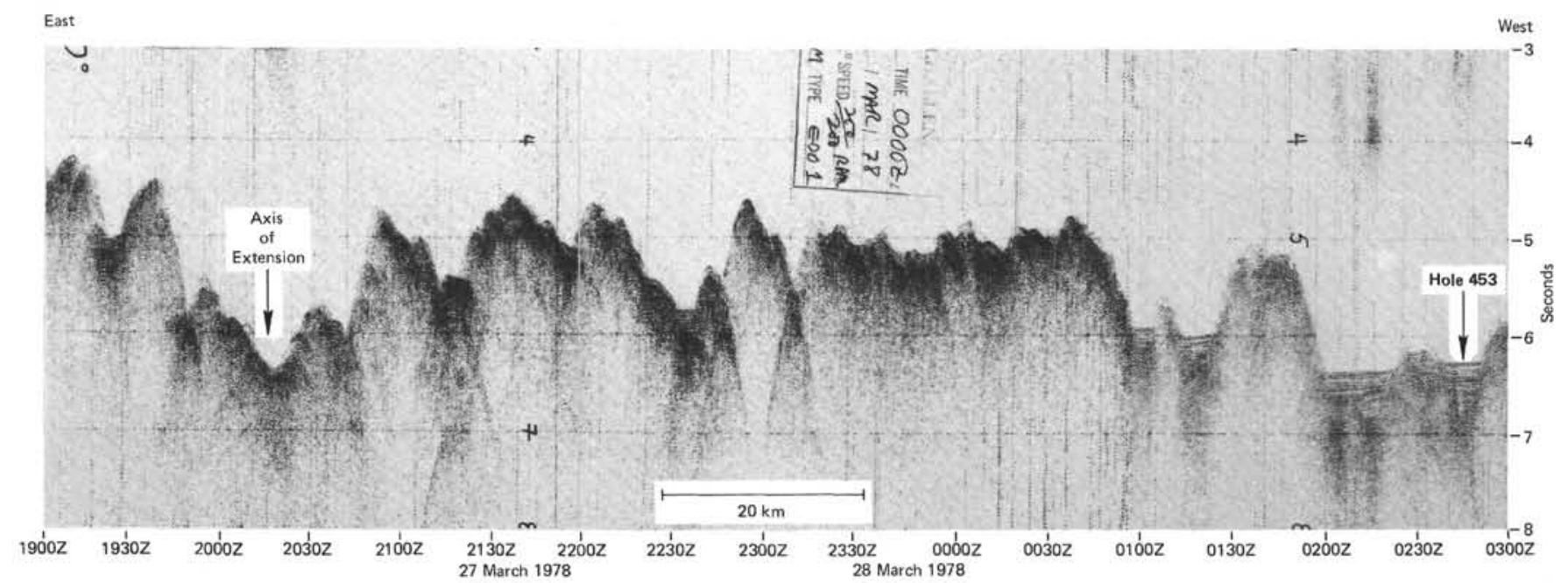

Figure 2. Glomar Challenger reflection seismic record across the western portion of the Mariana Trough. This profile extends across the entire Leg 60 drilling area and is discussed in detail by Hussong (this volume). 
4) Heat flow is around $0.5-1.5$ HFU (later measurements include some $>20 \mathrm{HFU}$; Hobart et al., 1979);

5) From refraction data the crust averages around $5.5 \mathrm{~km}$ thick, with an unusually thick $(1.5 \mathrm{-km})$ Layer $2 \mathrm{~A}$ $(4-5 \mathrm{~km} / \mathrm{s})$ and a Moho averaging $10.5 \mathrm{~km}$ beneath sea level;

6) Basement velocities beneath the sediment ponds are characteristically higher than in the bathymetric highs; and

7) SP4-F is approximately $10 \mathrm{~km}$ east of the eastern edge of the West Mariana Ridge remnant arc, and 120 $\mathrm{km}$ west of the apparent axis of spreading in the Mariana Trough (Fig. 2).

\section{OPERATIONS}

The transit from Hole 452 A to Site 453 provided the opportunity to make a geophysical traverse of all the targets between SP-1 and SP-4, which was accomplished using the reflection seismic system with a 120 -cu. in. air gun, the $3.5-\mathrm{kHz}$ and $12-\mathrm{kHz}$ PDR's, and the magnetometer. The results of the traverse are described by Hussong (Underway Geophysics, this volume).

The approach to Site 453 was controlled largely by comparison of bottom and sub-bottom structure observed by Hawaii Institute of Geophysics and LamontDoherty Geological Observatory site surveys, with the seismic profiles collected on the Challenger. The sediment ponds, even in this oldest and deepest western edge of the Mariana Trough, are only a few kilometers across and are not interconnected, so each small pond has a distinctive depth. It is therefore possible to keep track of the ship's location in well-surveyed areas in the Mariana Trough by monitoring sediment-pond depths.

A $16-\mathrm{kHz}$ double-life beacon was dropped at 1318 on 28 March, during the second pass of the ship over the target sediment pond (see Geophysics section, this chapter, for a description of the target sediment pond). The beacon was dropped on the western side of the pond, where the sediment was not as deep as at the center, in order to limit the total sediment thickness that would have to be cored. It was estimated, based on the shipboard reflection records, that the total sediment thickness under the beacon was approximately 600 meters.

No further survey work was conducted until after completion of the drilling.

With plenty of sediment and excellent weather, a standard F94CK bit and 120-meter bottom-hole assembly was rigged. The pipe string was run and bottom felt and cored at a pipe string depth of 4703 meters at 2330 , local time.

The first three cores were obtained without rotation, and subsequent drilling of the first 30 cores was rapid (Fig. 3; Table 1).

The Tokyo T-probe was run after Core 9; it obtained a good measurement that yielded a heat flow value of $2.40 \mathrm{HFU}$ at 75.5 meters sub-bottom depth. Deployment of this instrument, which is mounted on the downhole water sampling device, was accomplished with no problems. The heat flow measurement took a total of 48

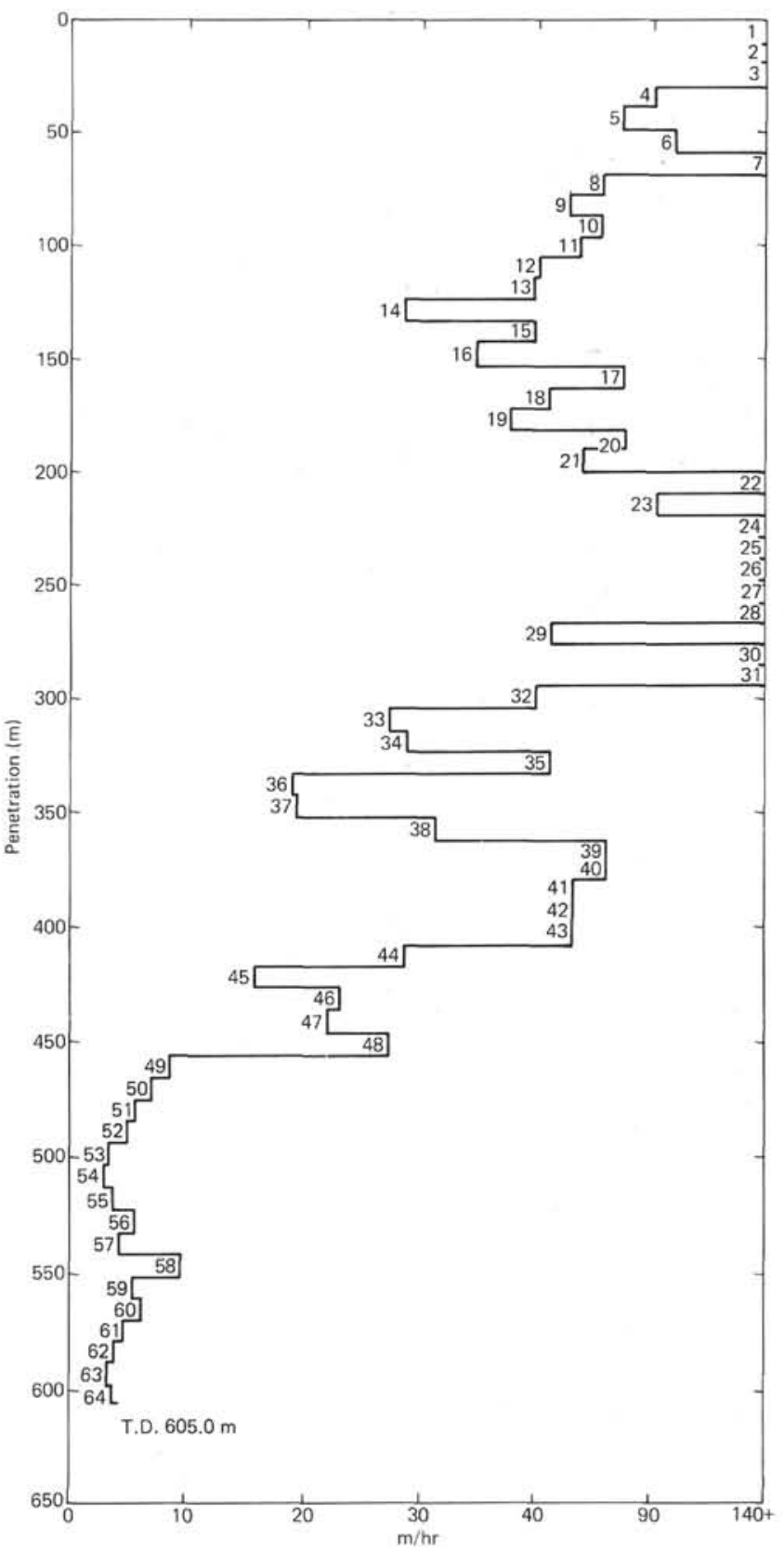

Figure 3. Drilling rate per core, Site 453. T.D. = total depth. Core numbers are indicated on the figure.

minutes in the hole, but in the future the time for measurement could be substantially reduced since the measured values reached equilibrium even more quickly than anticipated (see Uyeda and Horai, this volume).

Drilling rates slowed after Core 31 (294 m subbottom), in apparent response to an increase in the degree of lithification of the sediments. Beyond 455.5 meters below the sea floor, the drilling rate slowed to an average of 4.5 meters per hour as the bit penetrated a possible talus pile of igneous rocks, breccias, and deeper metamorphic rocks. Under these severe drilling conditions, bit wear became a concern. Recovery of the igneous rocks from Cores 48 through 57 was 33 per cent, but from Core 58 through Core 64 the recovery dropped 
Table 1. Coring summary, Hole 453.

\begin{tabular}{|c|c|c|c|c|c|c|c|}
\hline Core & $\begin{array}{c}\text { Date } \\
(1978)\end{array}$ & Time & $\begin{array}{l}\text { Depth from } \\
\text { Drill Floor } \\
\text { (m) }\end{array}$ & $\begin{array}{l}\text { Depth below } \\
\text { Sea Floor } \\
\text { (m) }\end{array}$ & $\begin{array}{l}\text { Length } \\
\text { Cored } \\
\text { (m) }\end{array}$ & $\begin{array}{l}\text { Length } \\
\text { Recovered } \\
\text { (m) }\end{array}$ & $\begin{array}{c}\text { Recovery } \\
(\%)\end{array}$ \\
\hline 1 & $3 / 29$ & 0034 & $4703.0-4712.0$ & $0-9.0$ & 9.0 & 9.23 & 100 \\
\hline 2 & $3 / 29$ & 0157 & $4712.0-4721.5$ & $9.0-18.5$ & 9.5 & 6.15 & 64.7 \\
\hline 3 & $3 / 29$ & 0315 & $4721.5-4731.0$ & $18.5-28.0$ & 9.5 & 3.35 & 35.3 \\
\hline 4 & $3 / 29$ & 0440 & $4731.0-4740.5$ & $28.0-37.5$ & 9.5 & 8.56 & 90.1 \\
\hline 5 & $3 / 29$ & 0558 & $4740.5-4750.0$ & $37.5-47.0$ & 9.5 & 2.44 & 25.7 \\
\hline 6 & $3 / 29$ & 0717 & $4750.0-4759.5$ & $47.0-56.5$ & 9.5 & 1.75 & 18.4 \\
\hline 7 & $3 / 29$ & 0838 & $4759.5-4769.0$ & $56.5-66.0$ & 9.5 & 0.25 & 2.6 \\
\hline 8 & $3 / 29$ & 1004 & $4769.0-4778.5$ & $66.0-75.5$ & 9.5 & 6.20 & 65.2 \\
\hline 9 & $3 / 29$ & 1334 & $4778.5-4788.0$ & $75.5-85.0$ & 9.5 & 0.45 & 4.7 \\
\hline 10 & $3 / 29$ & 1503 & $4788.0-4797.5$ & $85.0-94.5$ & 9.5 & 3.90 & 41.4 \\
\hline 11 & $3 / 29$ & 1623 & $4797.5-4807.0$ & $94.5-104.0$ & 9.5 & 9.57 & 100 \\
\hline 12 & $3 / 29$ & 1757 & $4807.0-4816.5$ & $104.0-113.5$ & 9.5 & 8.71 & 91.7 \\
\hline 13 & $3 / 29$ & 1936 & $4816.5-4826.0$ & $113.5-123.0$ & 9.5 & 1.55 & 16.3 \\
\hline 14 & $3 / 29$ & 2108 & $4826.0-4835.5$ & $123.0-132.5$ & 9.5 & 3.03 & 31.9 \\
\hline 15 & $3 / 29$ & 2240 & $4835.5-4845.0$ & $132.5-142.0$ & 9.5 & 3.90 & 41.1 \\
\hline 16 & $3 / 30$ & 0021 & $4845.0-4854.5$ & $142.0-151.5$ & 9.5 & 0 & 0 \\
\hline 17 & $3 / 30$ & 0144 & $4854.5-4864.0$ & $151.5-161.0$ & 9.5 & 0.78 & 8.2 \\
\hline 18 & $3 / 30$ & 0312 & $4864.0-4873.5$ & $161,0-170.5$ & 9.5 & 9.70 & 100 \\
\hline 19 & $3 / 30$ & 0450 & $4873.5-4883.0$ & $170.5-180.0$ & 9.5 & 0.87 & 9.2 \\
\hline 20 & $3 / 30$ & 0610 & $4883.0-4892.5$ & $180.0-189.5$ & 9.5 & 4.5 & 47.4 \\
\hline 21 & $3 / 30$ & 0745 & $4892.5-4902.0$ & $189.5-199.0$ & 9.5 & 2.2 & 23.2 \\
\hline 22 & $3 / 30$ & 0909 & $4902.0-4911.5$ & $199.0-208.5$ & 9.5 & 3.5 & 36.8 \\
\hline 23 & $3 / 30$ & 1025 & $4911.5-4921.0$ & $208.5-218.0$ & 9.5 & 2.23 & 23.5 \\
\hline 24 & $3 / 30$ & 1150 & $4921.0-4930.5$ & $218.0-227.5$ & 9.5 & 3.39 & 35.6 \\
\hline 25 & $3 / 30$ & 1317 & $4930.5-4940.0$ & $227.5-237.0$ & 9.5 & 1.99 & 20.9 \\
\hline 26 & $3 / 30$ & 1430 & $4940.0-4949.5$ & $237.0-246.5$ & 9.5 & 5.66 & 59.6 \\
\hline 27 & $3 / 30$ & 1520 & $4949.5-4959.0$ & $246.5-256.0$ & 9.5 & 3.86 & 40.6 \\
\hline 28 & $3 / 30$ & 1710 & $4959.0-4968.5$ & $256.0-265.5$ & 9.5 & 2.18 & 22.9 \\
\hline 29 & $3 / 30$ & 1832 & $4968.5-4978.0$ & $265.5-275.0$ & 9.5 & 6.37 & 67.1 \\
\hline 30 & $3 / 30$ & 1952 & $4978.0-4987.5$ & $275.0-284.5$ & 9.5 & 1.25 & 13.2 \\
\hline 31 & $3 / 30$ & 2121 & $4987.5-4997.0$ & $284.5-294.0$ & 9.5 & 4.62 & 48.6 \\
\hline 32 & $3 / 30$ & 2304 & $4997.0-5006.5$ & $294.0-303.5$ & 9.5 & 4.23 & 44.5 \\
\hline 33 & $3 / 31$ & 0056 & $5006.5-5016.0$ & $303.5-313.0$ & 9.5 & 5.28 & 55.6 \\
\hline 34 & $3 / 31$ & 0243 & $5016.0-5025.5$ & $313.0-322.5$ & 9.5 & 4.94 & 52.0 \\
\hline 35 & $3 / 31$ & 0414 & $5025.5-5035.0$ & $322.5-332.0$ & 9.5 & 5.91 & 62.2 \\
\hline 36 & $3 / 31$ & 0604 & $5035.0-5044.5$ & $332,0-341.5$ & 9.5 & 7.67 & 80.7 \\
\hline 37 & $3 / 31$ & 0750 & $5044.5-5054.0$ & $341.5-351.0$ & 9.5 & 7.08 & 74.5 \\
\hline 38 & $3 / 31$ & 0933 & $5054.0-5063.5$ & $351.0-360.5$ & 9.5 & 3.47 & 36.5 \\
\hline 39 & $3 / 31$ & 1056 & $5063.5-5073.0$ & $360.5-370.0$ & 9.5 & 6.92 & 72.8 \\
\hline 40 & $3 / 31$ & 1218 & $5073.0-5082.5$ & $370.0-379.5$ & 9.5 & 5.5 & 57,9 \\
\hline 41 & $3 / 31$ & 1351 & $5082.5-5092.0$ & $379.5-389.0$ & 9.5 & 7.55 & 79.4 \\
\hline 42 & $3 / 31$ & 1514 & $5092.0-5101.5$ & $389.0-398.5$ & 9.5 & 3.06 & 32.2 \\
\hline 43 & $3 / 31$ & 1647 & $5101.5-5111.0$ & $398.5-408.0$ & 9.5 & 4.38 & 46.1 \\
\hline 44 & $3 / 31$ & 1813 & $5111.0-5120.5$ & $408.0-417.5$ & 9.5 & 2.99 & 31.4 \\
\hline 45 & $3 / 31$ & 2013 & $5120.5-5130.0$ & $417.5-427.0$ & 9.5 & 5.79 & 60.9 \\
\hline 46 & $3 / 31$ & 2206 & $5130.0-5139.5$ & $427.0-436.5$ & 9.5 & 1.70 & 17.9 \\
\hline 47 & $3 / 31$ & 2344 & $5139.5-5149.0$ & $436.5-446.0$ & 9.5 & 4.18 & 44.0 \\
\hline 48 & $4 / 1$ & 0132 & $5149.0-5158.5$ & $446.0-455.5$ & 9.5 & 0.74 & 7.8 \\
\hline 49 & $4 / 1$ & 0407 & $5158.5-5168.0$ & $455.5-465.0$ & 9.5 & 1.73 & 18.2 \\
\hline 50 & $4 / 1$ & 0708 & $5168.0-5177.5$ & $465.0-474.5$ & 9.5 & 1.44 & 15.2 \\
\hline 51 & $4 / 1$ & 1010 & $5177.5-5187.0$ & $474.5-484.0$ & 9.5 & 4.11 & 43.2 \\
\hline 52 & $4 / 1$ & 1323 & $5187.0-5196.5$ & $484,0-493.5$ & 9.5 & 2.21 & 23.2 \\
\hline 53 & $4 / 1$ & 1809 & $5196.5-5206.0$ & $493.5-503.0$ & 9.5 & 5.91 & 62.2 \\
\hline 54 & $4 / 1$ & 2312 & $5206.0-5215.5$ & $503.0-512.5$ & 9.5 & 3.51 & 36.9 \\
\hline 55 & $4 / 2$ & 0458 & $5215.5-5225.0$ & $512.5-522.0$ & 9.5 & 4.82 & 50,7 \\
\hline 56 & $4 / 2$ & 0817 & $5225.0-5234.5$ & $522.0-531.5$ & 9.5 & 1.85 & 19.4 \\
\hline 57 & $4 / 2$ & 1209 & $5234.5-5244.0$ & $531.5-541.0$ & 9.5 & 5.06 & 53.2 \\
\hline 58 & $4 / 2$ & 1504 & $5244.0-5253.5$ & $541.0-550.5$ & 9.5 & 0,40 & 4.2 \\
\hline 59 & $4 / 2$ & 1840 & $5253.5-5263.0$ & $550.5-560.0$ & 9.5 & 0.24 & 2.5 \\
\hline 60 & $4 / 2$ & 2139 & $5263.0-5272.5$ & $560.0-569.5$ & 9.5 & 0.12 & 1.2 \\
\hline 61 & $4 / 3$ & 0105 & $5272.5-5282.0$ & $569.5-579.0$ & 9.5 & 0.2 & 2.0 \\
\hline 62 & $4 / 3$ & 0450 & $5282.0-5291.5$ & $579.0-588.5$ & 9.5 & 0.21 & 2.2 \\
\hline 63 & $4 / 3$ & 0940 & $5291.5-5301.0$ & $588.5-598.0$ & 9.5 & 1.43 & 15.0 \\
\hline 64 & $4 / 3$ & 1300 & $5301.0-5308.0$ & $598.0-605.0$ & 7.0 & 0.06 & 0.8 \\
\hline Total & & & & & $\overline{605.0}$ & $\overline{236.83}$ & 39.1 \\
\hline
\end{tabular}

to 4.1 per cent, even though the recovered rocks were apparently less dense in the deeper cores.

Various combinations of bit weight and pumping pressure were tried, and the hole was twice flushed with mud, but the percentage of recovery did not improve. After torquing increased dramatically during the cutting of Core 64, we decided that the bit was no longer operational, so drilling was stopped after 7 meters penetration on that cut. On recovery, the single cored rock that was recovered had only about a half of the diameter of a normal core, indicating that the cone bearings on the bit had been destroyed.

The hole reached a total depth of 605 meters below the sea floor, of which 137 meters had penetrated igneous rocks. The bit was rotated for 42 hours and 32 minutes before its apparent destruction. Sample re- covery was 236.8 meters $(39 \%)$ of the material penetrated.

After drilling was halted, preparation began for running a full set of downhole logs. We had decided to log the hole filled with salt water, rather than mud, since the water was required for the planned experimental largescale resistivity log. In preparation, some 150 barrels of mud were circulated through the hole to flush it out, the bit was released, and the pipe was raised to 187 meters below the sea bottom. We had planned to lift all the drill string and leave only the 120-meter bottom-hole assembly in the hole, but heavy lifting loads on the string indicated that the shallow portions of the hole were caving in around the pipe during extraction. With the bottom of the string around 150 meters sub-bottom, lifting was halted. To clear the potential bridging in the upper part of the hole, four joints were replaced and the bottom of the string was pumped down to 186 meters sub-bottom. During this operation a $40,000-\mathrm{lb}$ drop in weight occurred.

Logging commenced at 1930. The first tool to be lowered was to have been the temperature probe. The danger that the drill hole might be bridged prompted replacement of the T-probe with the heavier gammaneutron activation and laterolog probe which more likely would drop through minor sediment bridges in the hole, and which would also give a continuous data readout on the ship indicating movement through the drill hole.

The probe was lowered to a depth of 4677.5 meters, where it was stopped by an apparent bend in the drill pipe. The rotary shifting tool for the bit release had been run at 1400-1530 and had not become stuck (although it is a larger tool than the log). We concluded therefore that the drill pipe became bent between 1530 and 1930 , possibly when the the $40,000-\mathrm{lb}$ drop in weight occurred.

As it was not possible to run the Gearhart-Owen downhole tools, the cause and nature of the bend in the pipe were unknown, and the top of the hole was apparently unstable, we decided to abandon Hole 453 without attempting the Francis large-scale resistivity log. Were the large-scale resistivity log to have encountered an obstruction in the pipe or the hole, it would have been difficult to detect before slacking and possibly snarling the sand line.

The string was pulled and secured at 0942 on 4 April, 1978. The third section of pipe above the bottom-hole assembly was bent.

Before departure for Site SP-4F, a short survey around the Site 453 pond was conducted in order to define the approximate shape of the pond and the surrounding ridges. The results of this work are detailed in the Geophysics section of this chapter.

At 1406 on 4 April the Challenger departed from Site 453 on a course of $081^{\circ}$ for target Site SP-4E.

\section{LITHOLOGY}

The clastic fill of the sediment pond in which Site 453 was located comprises two units. The upper part (Fig. 4) is a sequence of $\mathbf{4 5 5 . 5}$ meters of muds, silts, and sands 


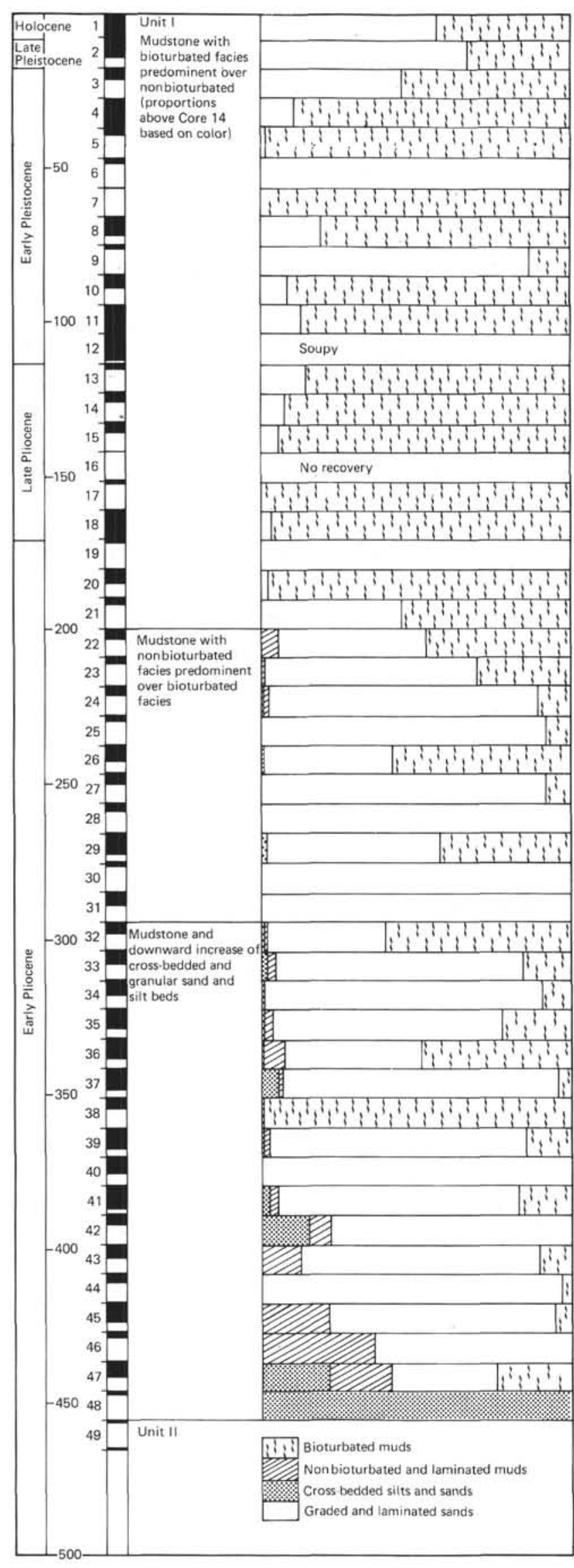

Figure 4. Stratigraphic column for Site 453 showing proportions of lithologies in each core.
(Unit I) composed mainly of volcanogenic detritus overlying a polymict breccia containing gabbro and basalt fragments (Unit II). The seismic reflection record shows Unit I to be flat-lying in the upper 100 meters and slightly undulating in the lower part.

The oldest fossils found are from the early Pliocene nannofossil subzone of Triquetrorhabdulus rugosus. The zone is regarded by some authors as uppermost Miocene, but using the scheme of Ellis and Lohman (1979) we place this subzone in its entirety in the early Pliocene; thus, the oldest sediment is 4.7 to $5 \mathrm{~m}$.y. old. A similar age is inferred from paleomagnetic studies on the sediments of the unit.

The sediments are soft and unlithified in the first 12 cores, semilithified for the next eight to 10 cores, and lithified in the lower cores.

\section{Stratigraphy}

Two alternating lithological associations are found in Unit I. They are identified by their sedimentary structures, grain size, bioturbation, and (to a lesser extent) color. In the uppermost 13 cores where sedimentary structures have been destroyed by drilling, identification has been based mainly on color.

\section{Strongly Bioturbated Beds}

The bioturbated sequence is almost entirely silt and mud, and the color is distinctly more green than the non-bioturbated association. Burrows are generally large ( $5 \mathrm{~mm}$ to $1 \mathrm{~cm})$, and predominantly parallel to the bedding; they are often clearer in the upper parts of the beds, while the lower parts are color-mottled. Indistinct laminations are sometimes found. Burrow fillings are normally paler than the bulk of the sediment, and examination of one very pale infilling revealed a high carbonate content including abundant nannofossil remains. Apart from these minor occurrences, nannofossils are extremely rare in this association.

In the upper part of Unit I, beds of this lithology over 6 meters thick have been recovered (Core 18), but in the basal 100 meters of the unit the thickest bed is $60 \mathrm{~cm}$.

\section{Nonbioturbated Beds}

Beds of this association are browner in color than the strongly bioturbated beds and are almost always graded although most of each bed is in the mud size range. Coarseness of the beds increases with depth in Unit I. The "typical" bed of this association, from the base up, comprises (1) a graded sand (medium to fine grained at the bottom and very fine grained at the top) with some laminations and an erosional base, (2) a very fine sandy to silty layer with small-scale cross-bedding (ripple lamination), (3) laminated siltstone fining up into mudstone (laminations from $1 \mathrm{~mm}$ to $1 \mathrm{~cm}$ apart), (4) mudstone with few laminations but usually with regular flat partings, few laminations, and rare narrow $(2-4 \mathrm{~mm})$ vertical burrows, (5) a fine laminated zone with laminations up to several centimeters apart containing the greatest (but small) concentration of nannofossils.

On the barrel sheets and in the petrographic discussion that follows, the sediments are classified as tuffs 
(indurated) and ashes (non-indurated) if they contain over 50 per cent volcanogenic detritus (see Introductory Chapter, this volume).

The thickest bed recovered belonging to this association is over 8 meters thick, but beds of 1 to 2 meters are more typical. Within the beds the greatest variation occurs in the lowest part, the cross-bedded layer being replaced in many cases by a graded silt-to-very-finesand layer or a graded silt layer. The coarsest sand layer is occasionally reduced to a single band or a layer less than $1 \mathrm{~cm}$ thick with cross-bedding. The bedding of the cross-bedded layer is suggestive of climbing ripples in Core 47.

Sedimentary structures observed in the lower laminated sequence include small-scale structures, smallscale graded bedding, cross-bedding of interbedded silt laminae and mudstone, and in Core 47 several centimeters of flaser-bedded silt laminae.

The proportions of the various lithologies are shown in the stratigraphic column (Fig. 4). The reliability of the proportions should be judged against the recovery for the core. There is a rapid upward decrease in the proportion of coarser sediment over the basal 80 meters of the unit. The highest cross-bedded unit is in Core 20 (180-189.5 m). Above the top of Core 21 (189.5), just below the early/late Pliocene boundary, there is a sharp increase in the proportion of bioturbated sediments. There is no significant change in the sediment assimilation rate associated with this change in bioturbation. The sediment accumulation rate at this time had slowed to approximately $4.5 \mathrm{~kg} / \mathrm{cm}^{2} / \mathrm{m}$.y. and continues to decrease with time (see Accumulation Rates, this chapter).

Siliceous fossils are present in the first three cores but rapidly decrease in abundance downward.

A single carbonate-rich layer was recovered. It is a graded bed $17 \mathrm{~cm}$ thick and strongly burrowed at the top, overlain by bioturbated mudstone with mudstone filling the burrows.

\section{Sedimentary Petrography}

Several mineralogic associations more or less dependent on grain size can be differentiated in Unit I. The sediment supply is almost exclusively volcanic. Siliceous organisms are abundant at the top of the hole but are extremely rare below. In contrast, calcareous remains are found throughout the core, but they are rare.

Siliceous ooze and siliceous mud. Siliceous sediments with up to 70 per cent diatoms and radiolarians are present in Cores 1 through 3 in the most recent sediments. The other major components are clay and traces of micronodules, glass, and feldspar.

Clay and claystone. These contain 90 to 98 per cent clay plus traces of feldspars, pyroxene, zeolites, volcanic glass, and micronodules. This lithology is found at intervals throughout the unit below Core 3 .

Mud and mudstone. Up to 10 percent of feldspar, pyroxene, and glass are present in these sediments together with up to 90 per cent clay; their texture is more silty.
Volcanoclastic-rich layers (vitric-lithic clay, mud, non-indurated ash, indurated tuff). Volcanoclastic elements are very abundant and dispersed throughout the whole unit. They tend to be more abundant in nonbioturbated sediments when compared with bioturbated sediments of the same grain size. Volcanic components can constitute up to 80 per cent of the silt- and sandsized sediments. Volcanic glass is the most abundant component, followed by feldspar, heavy minerals, and volcanic rock fragments. Within a single graded sequence of non-bioturbated sediments volcanoclastic components increase markedly downward, simultaneously with grain size (Fig. 5).

The most abundant type of the glass is very pale yellow and angular with closely spaced, thin pipe vesicles. Also present are colorless bubble-wall fragments, and colorless, pale brown and pale green glasses of other morphologies. The colorless ones, including those with pipe vesicles, have a lower index of refraction indicating that their compositions are more silicic. Pale green colored glass occurs in Cores 8 and deeper cores.

Superimposed on the above variability, volcanic glasses become increasingly brownish downward as a result of their alteration into clay minerals, thus making the recognition of the various types more difficult deeper in the unit. Heavy minerals are scanty, clinopyroxene is present in most sandy samples, and orthopyroxene appears in Cores 8,13 , and 39 . In Core 13 it is a major component of a muddy vitric crystal tuff layer which is $0.5 \mathrm{~cm}$ thick.

Other minerals. Opaque "micronodule"-rich layers are often present in Unit I and are often associated with zeolites and pale volcanic glass. Microprobe examination of the "micronodules" has shown them to be very dark, iron-rich basaltic glass fragments. Small amounts of carbonate (dolomite?) occur in some intervals (Cores 18 and 36 ), as does minor pyrite (Core 44). Unidentified

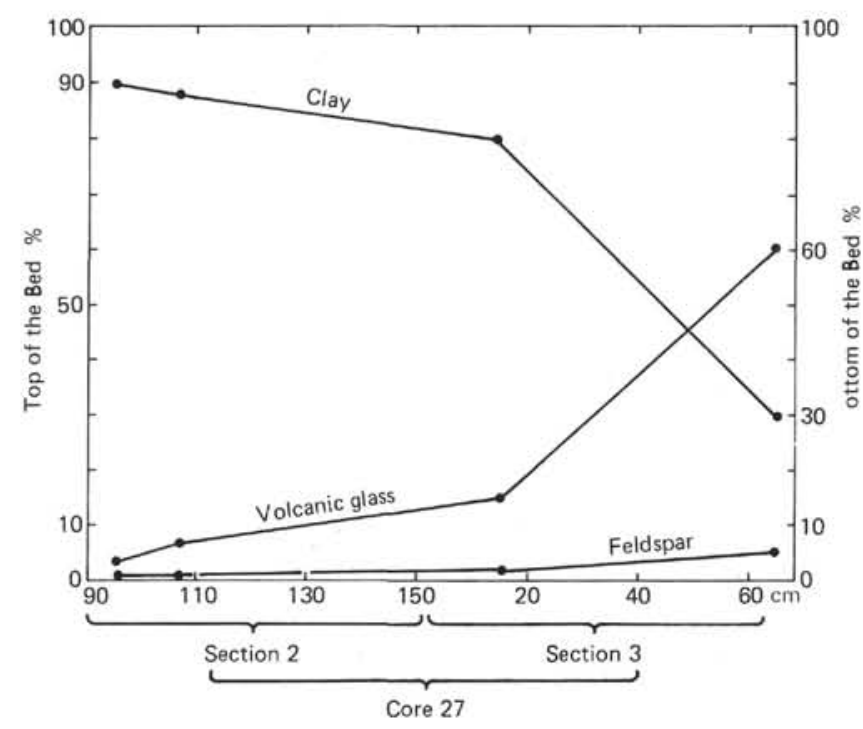

Figure 5. Change in composition within a graded bed of nonbioturbated mudstone estimated from smear slide determinations. 
carbonate (dolomite?) in Core 36 constitutes almost all the light-colored burrow fills in the claystone.

\section{Deposition of the Sediments}

Each of the sediment ponds in the region of Site 453 is isolated from adjacent ponds by intervening ridges and hills. The rough ridge and pond topography prevents the direct inflow of sediments from the possibly western source, the West Mariana Ridge, and the more remote Mariana Island arc to the east. The sediment composition indicates that the detritus is almost exclusively of volcanic origin, and the sedimentary structure show that pond fill was mainly laid down by turbidity current deposition with intervening periods of slower pelagic or hemipelagic accumulation during which the sediments were strongly bioturbated. Because of the extremely low abundance of biogenic elements, these sediments are thought to have been deposited close to the carbonate compensation depth (CCD). The turbidites are unusual in that the upper laminated sequence of the idealized turbidite is by far the thickest and the most commonly developed. The ripple-laminated and gradedsand sequences occur frequently only in the basal third of Unit I. There is an overall decrease of grain size up the sedimentary column. No true ash fall layers have yet been identified in the sequence. If they did occur, they may have formed thin bands in the slowly deposited strongly bioturbated layers and their identity has been subsequently lost.

The most abundant volcanic glass in the sediments has a low refractive index and is assumed to be ultimately derived from an island arc, rather than from volcanism within the basin. The more likely source is the Mariana Arc, where currently active volcanoes are located, rather than the West Mariana Ridge which is now entirely submerged. Drilling at Site 451 on the West Mariana Ridge revealed a thin, fine-grained Pliocene-Pleistocene section with no apparent volcanic ash above the early Pliocene (Scott, Kroenke, et al., 1980).

The immediate but not primary sources of the Site 453 sediment are the ridges surrounding the basin. We assume that sediment from Mariana Arc volcanism accumulated on these ridges and was mobilized into turbidity flows triggered by seismicity within the basin, by ash showers, or by slope instability.

\section{BIOSTRATIGRAPHY}

\section{Summary}

Evidence from generally common occurrences of calcareous nannofossils and rare occurrences of radiolarians (in the upper four cores) indicates that the sedimentary interval (Cores 1 through 48 ) overlying the igneous breccia (Core 49 and below) ranges in age from late Pleistocene to early Pliocene. Cores 1 and 2 are of late Pleistocene age, Cores 3 through 12 are early Pleistocene, Cores 13 through 18 are late Pliocene, and Cores 19 through 48 are early Pliocene. There is no evidence that Miocene sediments have been encountered, based on the comparison of nannofossil assemblages recov- ered at this site with those recovered from the Messinian (Miocene) stratotype section.

\section{Nannofossils}

Nannofossils observed in Pleistocene, late Pliocene, and latest early Pliocene samples (Cores 1 through 21) occur sparsely and are poorly preserved. However, the following zones can be recognized:

Late Pleistocene-the Gephyrocapsa oceanica Zone, Samples 1,CC and 2,CC.

Early Pleistocene-the Gephyrocapsa caribbeanica Subzone of the Crenalithus doronicoides Zone, Samples 3-2, 90-91 cm through 6,CC. The Emiliania annula Subzone of the $C$. doronicoides Zone, Samples 8,CC through 12,CC.

Late Pliocene-three of the four subzones of the Discoaster brouweri Zone can be recognized: the Discoaster pentaradiatus Subzone, Sample 13,CC; the Discoaster surculus Subzone, Samples 14-1, 20-21 cm through 14, CC; and the Discoaster tamalis Subzone, Samples 15-2, $90-91 \mathrm{~cm}$ through $18, \mathrm{CC}$.

Early Pliocene-the Discoaster asymmetricus Subzone of the Reticulofenestra pseudoumbilica Zone, Samples 19-1, 60-61 cm through 22-2, 90-91 cm.

Nannofossils occur more commonly and are moderately well preserved in early Pliocene samples. The following zones can be recognized in the early Pliocene:

The Sphenolithus neoabies Subzone of the Reticulofenestra pseudoumbilica Zone, Samples 22,CC through $27-1,90-91 \mathrm{~cm}$.

All three subzones of the Amaurolithus tricorniculatus Zone can be recognized: the Ceratolithus rugosus Subzone, Samples 27-2, 130-131 cm through 28-1, 50$51 \mathrm{~cm}$ or possibly $29-4,128-129 \mathrm{~cm}$; the Ceratolithus acutus Subzone, Samples 29,CC (or possibly 28,CC) through $38-2,59-60 \mathrm{~cm}$; and the Triquetrorhabdulus rugosus Subzone, Samples 38,CC through 48,CC. Samples below $44, C C$ do not contain early Pliocene zonal index species or any species used to define Miocene zones.

The Pliocene/Miocene boundary is placed at the base of the Triquetrorhabdulus rugosus Subzone. A recent study by Ellis and Lohman (1979) of the nannofossil assemblages recovered from the Zanclean (Pliocene) and Messinian (Miocene) stratotype sections in Sicily shows this position to be the most reasonable for the Pliocene/Miocene boundary. No Messinian-age nannofossil species were seen in the samples from Hole 453 .

Reworked Miocene nannofossils are not apparent in any of the Hole 453 samples. However, the Oligocene and late Eocene species Dictyococcites bisectus and the Oligocene species Cyclicargolithus abisectus are seen in Samples $43, C C$ and $47, C C$, respectively. Rare specimens of Discoaster deflandrei are also observed in Samples $43, \mathrm{CC}$ and $48, \mathrm{CC}$.

\section{Radiolarians}

Well-preserved radiolarians occur in Cores 1, 2, and 3. They are rare in the upper half of Core 4; the lower half is barren. Sporadic occurrences in lower cores are 
from regions of suspected drilling disturbance and contain no species indicating ages older than those of the first four cores. One exceptional occurrence is in Core 17, where badly altered radiolarians (no age-diagnostic forms recognizable) are filled with an unidentified isotropic crystalline mineral.

The radiolarians of Hole 453 are all of Quaternary age. Species on which Nigrini's (1971) zonation is based are very scarce, but enough can be found in the rich assemblages of the first three cores to permit recognition of the upper three zones: the Buccinosphaera invaginata Zone in Core 1, the Collosphaera tuberosa Zone in Cores 1 and 2, and the Amphirhopalum upsilon Zone in Cores 2 and 3.

\section{Foraminifers (V. A. Krasheninnikov)}

Rare foraminifers of Quaternary to Pliocene age occur in Sample 3-1, 50-52 cm.

\section{Accumulation Rates}

The sediment accumulation curve (Fig. 6) has been calculated in kilograms of water-free sediment per square centimeter. The weight of the sediment has been based on the porosity and grain density measurements. An average has been taken for each core; because the values obtained were a little erratic in the upper part of the core, a moving average over five cores has been used. The time lines are based on an estimate of the ages of the nannofossil zones determined in the cores using the time scale of Bukry (1975).

The total accumulation of detrital sediment is a little over $34 \mathrm{~kg} / \mathrm{cm}^{2}$ for the past $5 \mathrm{~m} . \mathrm{y}$. The rate of accumulation has declined with time from the inception of sedimentation, except for an interval between 0.9 and $1.8 \mathrm{~m} . \mathrm{y}$.. The sediments are almost entirely volcanogenic, and the organic contribution to the sediment column is significant only in Cores 1 and 2 deposited in the past 0.9 m.y. Smear slide estimates of samples from those cores give an average siliceous organic content of just over 20 per cent.

The stratigraphic column can be divided into three segments on the basis of sediment accumulation rates.

\begin{tabular}{lcc}
\hline \multicolumn{1}{c}{ Time Interval } & $\begin{array}{c}\text { Sub-Sea-Floor } \\
\text { Depth }(\mathrm{m})\end{array}$ & $\begin{array}{c}\text { Accumulation } \\
\text { Rate } \\
\left(\mathrm{kg} / \mathrm{cm}^{2} / \mathrm{m} . \mathrm{y} .\right)\end{array}$ \\
\hline 1) $\begin{array}{l}\text { Holocene and late } \\
\text { Pleistocene } \\
(0-0.9 \text { m.y. }\end{array}$ & $0-19.0$ & 0.9 \\
2) $\begin{array}{l}\text { Early Pleistocene } \\
(0.9-1.8 \text { m.y. })\end{array}$ & $19.0-112.7$ & 4.7 \\
3) $\begin{array}{l}\text { Pliocene } \\
(1.8-5 \text { m.y. })\end{array}$ & $112.7-446$ & $1.5 \rightarrow 31$ \\
\hline
\end{tabular}

The observed decrease in the rate of sedimentation with time at Site 453 would be predicted from its location if the active Mariana Arc were the sediment source. This site lies near the western edge of the Mariana Trough and west of the spreading center within the Trough. As spreading has taken place in the Mariana Trough, the distance from the pond in which the site is located to the active arc on the Mariana Ridge has in-

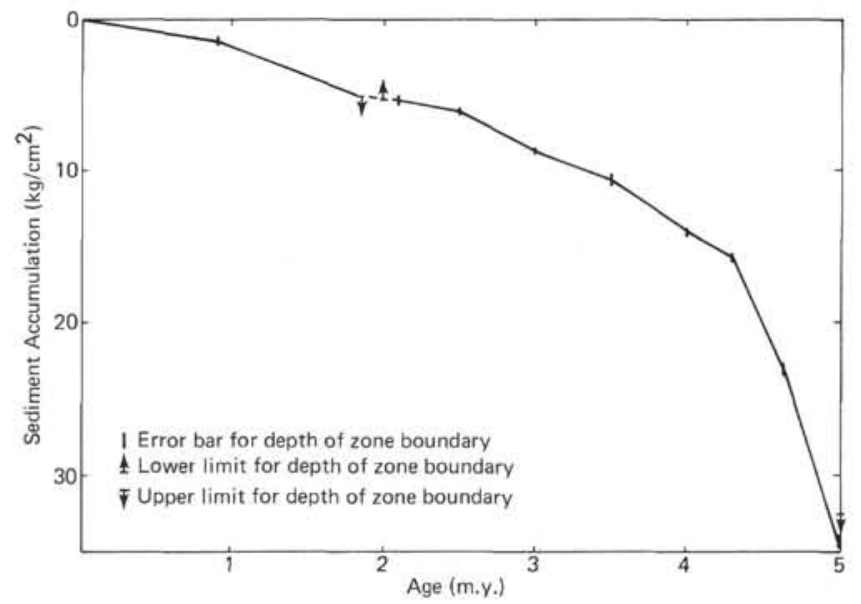

Figure 6. Sediment accumulation $\left(\mathrm{kg} / \mathrm{cm}^{2}\right)$ versus age, Site 453 .

creased. Deviations of the observed sediment accumulation from a simple curve may be attributed to changes in the level of volcanic activity, to fluctuation in spreading rates, or to imperfections in the dating of the biostratigraphic zonation.

The only significant deviation is the increase in the gradient of the accumulation curve in the early Pleistocene. The most likely explanation is an increase for a short period in the volcanic productivity of the arc. The steady upward decrease in the accumulation rate is reflected in changes in the style of sedimentation. There is an upward decreasing sediment grain size, an increase in the amount of bioturbation, and a decrease in the thickness of turbidite units.

Segment 2 sediments (early Pleistocene), in which more rapid sedimentation took place, are difficult to interpret because of drilling disturbance. The recovered sediment is not significantly coarser than the beds with a slower sedimentation rate immediately above and below. It is not clear whether the increased sedimentation rate applies to part or all of the interval.

\section{STRATIGRAPHIC SYNTHESIS}

The deposits which fill the pond where Site 453 is located consist of two distinct units:

Unit I-455.5 meters of volcaniclastics of mainly silt size with a minor pelagic component, and Unit IIpolymict breccias consisting mainly of fresh to altered and metamorphosed basaltic volcanic and plutonic rocks.

Unit I consists of the following components: pelagic sediments which have a persistent but minor role in the accumulation of the column, and volcaniclastic supplies which are superimposed as discrete contributions. The interplay of slow, continuous pelagic deposition and rapid but episodic volcanic-turbidite deposition generates the bioturbated and non-bioturbated beds (c.f., Lithology section, this chapter).

The entire pelagic-hemipelagic sediment sequence consists of claystone and mudstone or clay and mud (highly burrowed). In the two topmost cores, siliceous ooze containing radiolarians and diatoms are present. Zeolite is frequently well developed in clays. Carbonates are prac- 
tically absent from the sequence except in a few layers and in some burrows, where undetermined carbonate (possibly dolomite) occurs. Based on the state of microfossil preservation, it is unlikely that the sediment/water interface has been above the CCD since at least the earliest Pliocene (Ellis, this volume).

Volcaniclastic materials are present in almost all the cored samples. Even the clays contain up to 10 per cent very fine grained volcanic glass and feldspars. The concentration of these products is much higher in the silty and sandy graded beds which have turbidite characteristics - graded bedding, cross-bedding, lamination, etc. Two different modes of transportation and emplacement of these volcaniclastic materials are envisaged: (1) raining through the water column and (2) the flow of turbidity currents over the seafloor.

The deposits raining down through the water column could result from volcaniclastic air falls, ash flows over the sea surface, and the sinking of waterlogged pumice fragments. These volcanic glasses are dispersed through all the bioturbated units. Their sparse yet rather uniform occurrence suggests that they arrived in the vicinity by air fall or floating, originating from distant volcanoes.

The turbidity current deposits result from an instantaneous supply of suspended material to the basin floor. The currents could have been generated from either volcanic eruptions or non-volcanic events such as seismicity or slumping of volcanic debris deposited earlier from the surrounding hills.

The common occurrence of volcanic glasses of low refractive index throughout the unit (except for the three highest cores) and the sporadic presence of hypersthene-bearing tuffs and vitric muds suggest that episodic supply of volcaniclastics from subaerial island arctype volcanism continued since the earliest Pliocene until the latest early Pleistocene (Core 4). A change in the type of volcanic activity may have taken place at that time.

Small-scale normal faults with the displacement of the order of millimeters occur in the lower portion of the Unit I. On the other hand, no structures have been observed which show horizontal contractional deformation. These may suggest a pervasive extensional tectonic regime in the area during the opening period of the Mariana Trough.

Unit II is a 149.5 meter thick, complex igneous and metamorphic polymict breccia sequence which lies beneath Unit I down to the bottom of the hole. Details of its stratigraphy and petrography are reported in other sections of this report.

\section{History of the Region Adjacent to Site $\mathbf{4 5 3}$}

About five or more million years ago the crust in the vicinity of Site 453 was formed. This crust consists of blocks of igneous and metamorphic rocks down-dropped or uplifted from the West Mariana Ridge. The crust formation process and possible subsequent movements resulted in the present horst and graben basement structure of the western part of the Mariana Trough.
Since the initiation of pelagic sedimentation, the area remained close to, but below, the CCD up to the present time. Ashy turbidite layers are frequently interlayered with pelagic clay in the Pliocene, but diminish in abundance up the sequence and are rare by the early Pleistocene. This trend suggests an increased distance between Site 453 and the source volcanoes on the arc and/or a decline in the level of volcanic activity on the arc.

\section{INTERSTITIAL WATER GEOCHEMISTRY}

Pore waters were extracted from 12 samples at regular intervals throughout the $\mathbf{4 5 0}$ meters of sediment recovered at Site 453 . The data are listed and plotted versus depth in Gieskes and Johnson (this volume). As in many sites where the sediments are rich in volcanic glass, there is a sharp drop in $\mathrm{Mg}^{2+}$ and increase in $\mathrm{Ca}^{2+}$ with depth, apparently a consequence of exchange of sea-water $\mathrm{Mg}$ for $\mathrm{Ca}$ in glass during alteration to clay (e.g., Balshaw, this volume). However, just above the igneous polymict breccia at the base of the sediments, these trends abruptly reverse, with $\mathrm{Mg}$ and $\mathrm{Ca}$ values again approaching those of sea water. Gieskes and Johnson (this volume) interprets this to mean that sea water is being drawn down into the breccia sequence, perhaps via nearby basement outcrops, and is reaching the base of the sediment with little modification, perhaps because of hydrothermal circulation. Certainly, the higher but variable heat flow recorded in and near the site (Uyeda and Horai, this volume; Hobart et al., 1979) supports this interpretation.

\section{IGNEOUS AND METAMORPHIC ROCKS}

\section{Lithology}

Drilling at Site 453 penetrated 149.5 meters of complex polymict breccia and serpentinized rock beneath the sediments. The material recovered may be classified into three general categories based on gross lithologic changes with depth in the hole (Fig. 7). These are: (1) igneous polymict breccia with many small and a number of large $(>10 \mathrm{~cm})$ gabbro clasts $(0-85.5 \mathrm{~m}$ below the sediment/breccia interface), (2) polymict breccia consisting mainly of metavolcanics and metabreccia without large gabbro clasts (85.5-114 $\mathrm{m}$ below the interface), and (3) a sheared mafic gabbro zone (114-149.5 below the interface).

\section{Upper Polymict Breccia (0-85.5 m below sediments)}

The breccia interval is composed of angular to subrounded fragments of gabbro, diabase, and basalt cemented in a varicolored (mainly red-brown) matrix. The gabbro fragments range in proportion to basalt, metabasalt, and diabase in the cores from 54:46 to 95:5, and they average 71:29 (based on counts of clasts $>3 \mathrm{~cm}$ longest diameter on flat surfaces of working halves). They include fragments with color indices $>70$ (mafic gabbros), <30 (leucocratic and pegmatitic grabbros), and 30-70 (gabbros per se). The less abundant basaltic rocks include: (1) fine-grained aphyric or sparsely phyric basalt, (2) medium-grained aphyric basalt (dia- 


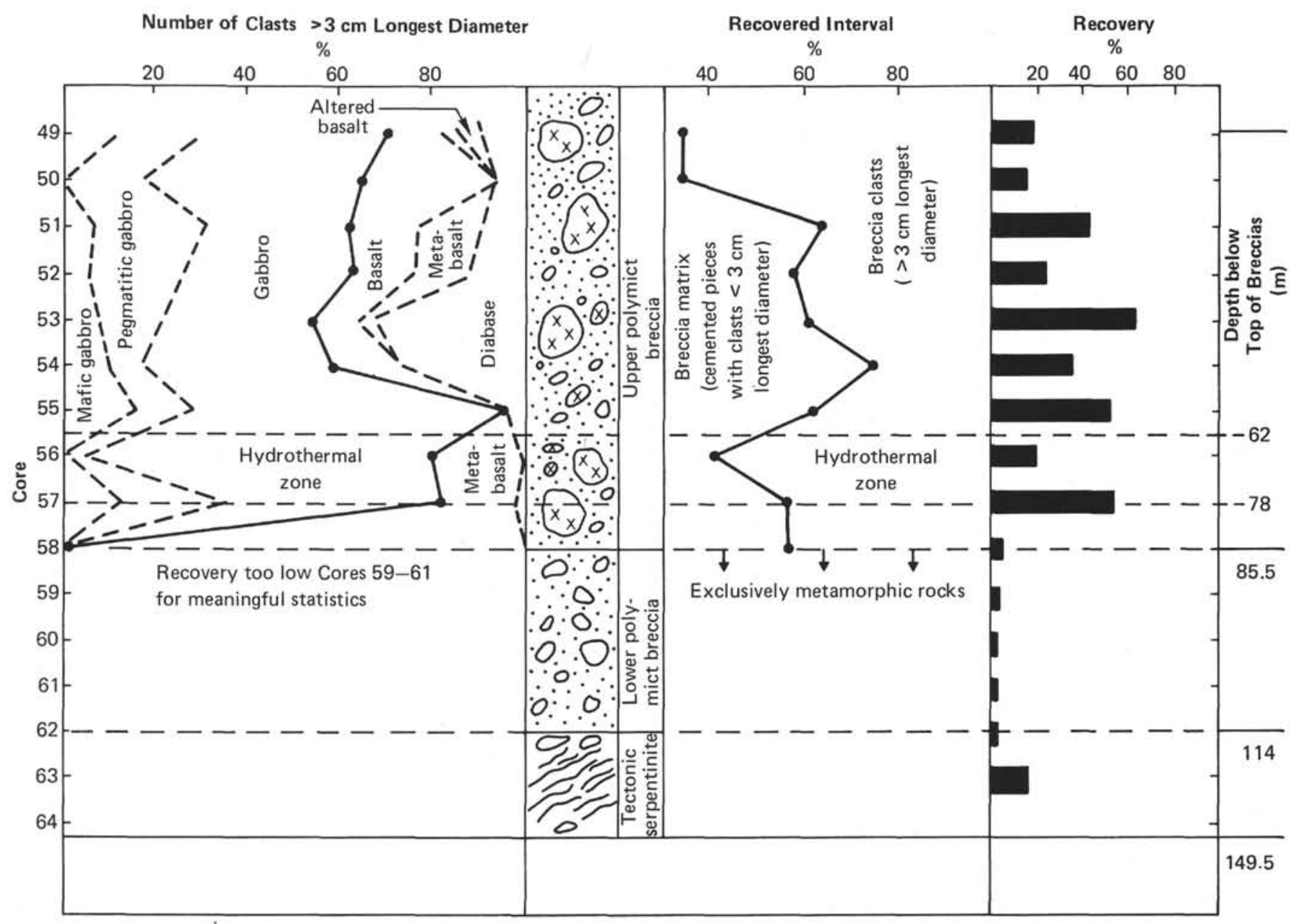

Figure 7. Variation with depth in core of (1) number of gabbro (dashed lines) and basalt (solid line) clasts, (2) lithology, (3) percentage of recovered breccia that is composed of clasts less than $3 \mathrm{~cm}$ (left) and greater than $3 \mathrm{~cm}$ (right), and (4) percentage of recovery.

base), (3) metabasalts, green in color, and (4) altered basalts, brown or reddish brown.

The rock fragments are cemented in a matrix of quartz, carbonate, iron oxide and hydroxides, and chlorite. The reddish color of the matrix is the result of oxidation of magnetites, or titanomagnetites, and (to a lesser degree) mafic silicate phases, to iron hydroxides, as seen using reflected light microscopy. Angular pebbles and sand-sized grains of igneous and metamorphosed igneous rocks are abundant throughout the matrix. Quartz crystals occur in some cavities and cracks between breccia fragments. Carbonate is most abundant in the upper intervals and diminishes with depth. It does not react readily with hydrochloric acid, hence does not appear to be entirely calcite.

Fragments in the breccia vary considerably in size. They range from sand-sized to clasts as large as $45 \mathrm{~cm}$. A size-frequency diagram for gabbro clasts larger than 3 $\mathrm{cm}$ in the longest diameter and basaltic clasts (includes metabasalts and diabases) larger than $2 \mathrm{~cm}$ in the longest diameter is presented in Figure 8A. The basaltic

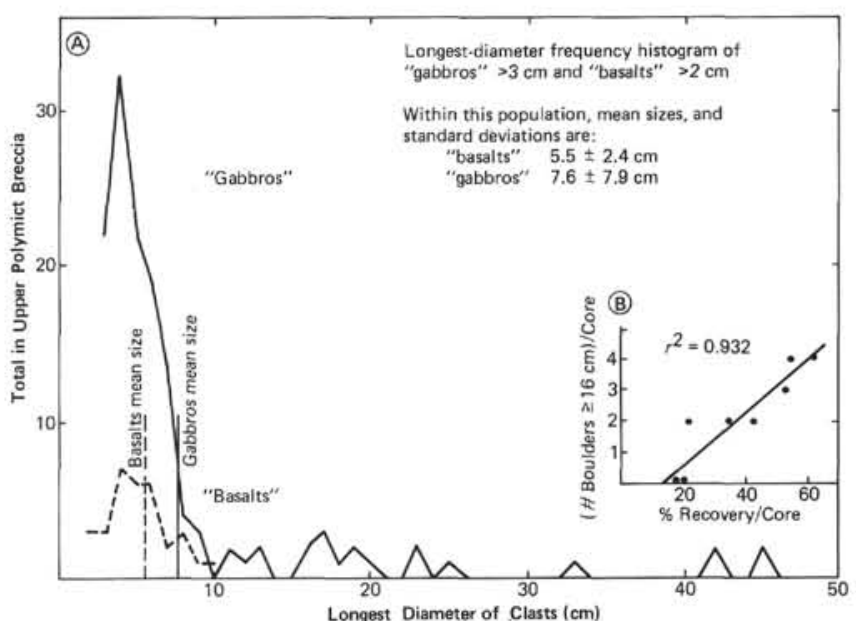

Figure 8. Size frequency diagram for basaltic clasts larger than $2 \mathrm{~cm}$ (dashed line) and gabbroic clasts larger than $3 \mathrm{~cm}$ (solid line). Vertical lines indicate the mean size of basaltic (dashed line) and gabbroic (solid line) clasts. 
rocks average $5.5 \mathrm{~cm}$ and the gabbros $7.6 \mathrm{~cm}$ in the longest measurable diameter.

There is a strong correlation between percentage recovery and size of gabbro clasts present (Fig. 8B). The correlation coefficient between the percentage recovery in each core and the number of large (16 $\mathrm{cm}$ or greater) gabbro clasts is 0.932 .

The proportion of various rocks types per core versus depth (based on gabbros larger than $3 \mathrm{~cm}$ in the longest diameter and basaltic rocks larger than $2 \mathrm{~cm}$ in the longest diameter) is plotted on Figure 7. On the basis of this diagram, the upper polymict breccia can be divided into less- and more-gabbroic zones. Above Core 55that is, to a depth of about 60 meters below the sediment/breccia interface - the gabbro clasts comprise 5470 per cent of all clasts larger than $3 \mathrm{~cm}$. In the gabbrorich zone, below 60 meters into the breccia, gabbro clasts comprise $80-95$ per cent of the total clasts larger than $3 \mathrm{~cm}$.

The 85.5-meters-thick gabbro-rich rocks include a zone where the breccia cement is green in color and consists mainly of chlorite. This zone starts with Core 55, Section 4, Piece 4, and continues through Core 57, Section 2, Pieces 14 through 16-a depth interval from about 62 to 78 meters below the sediment/breccia interface. Above and below this interval, the breccia matrix is grayish brown. The zone of green matrix contains demagnetized gabbros. Thin sections show that gabbros from this zone are more chloritized than those above or below. In Cores 55 and 56, some gabbros have highangle fractures with mafic minerals aligned parallel to the fractures, suggesting partial recrystallization. The demagnetized rocks are evidence that the green breccia matrix was probably a zone for flux of hydrothermal fluids at elevated temperatures.

Gabbros in this zone show retrograde metamorphic effects, apparently the result of the hydrothermal conditions they had been exposed to. Many have bleached exterior rinds in which calcic plagioclase has been transformed to K-feldspar (Fig. 9). Accompanying the color change in the matrix is an increasing abundance of quartz-K-feldspar chlorite veins within the rock clasts. Nearly all of the metabasalts and many gabbros in the low-gabbro zone were apparently metamorphosed prior to incorporation within the breccia.

Several zones in the upper polymict breccia have higher abundances of certain clasts than others. Cores 53 and 54 in the low-gabbro zone have a high proportion of medium-grained basalt ("diabase") as shown on Figure 7. Several of these basalts appear to have disaggregated within the breccia matrix. As a result of this, the breccia matrix surrounding them is a deep brick-red color.

Another zone with a predominant rock type is the green-matrix zone of Cores 55 and 56 . Here the proportion of pegmatitic gabbro is low (Fig. 7), and the gabbros have higher color indices than elsewhere $(50-70$ rather than 30-70).

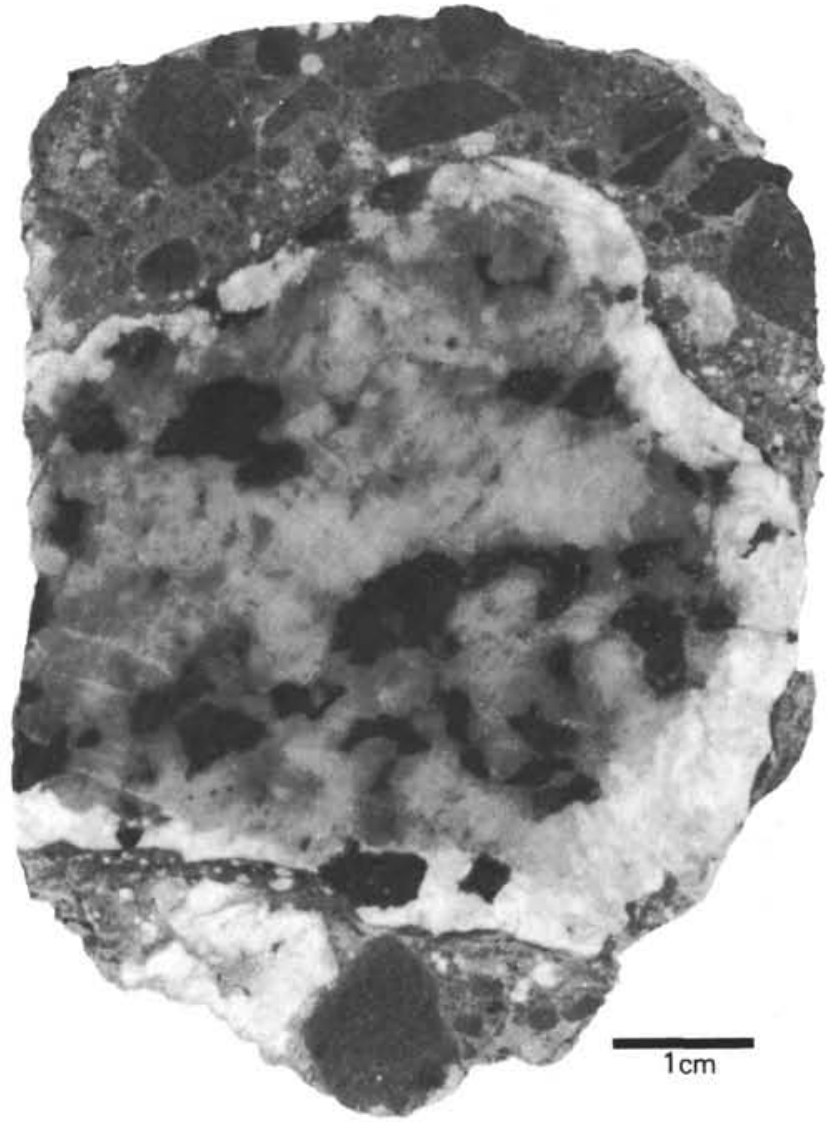

Figure 9. Gabbro clast with encrusting breccia and $\mathrm{K}$-feldspar alteration rind. Sample 453-57-2 (Piece 14), 83-89 cm.

\section{Lower Polymict Breccia (85.5-114 m below sediment)}

A principal feature of this interval is its low recovery (Fig. 7). The rock types that were recovered, although brecciated, differ in several respects from those of the upper polymict breccia.

The clast types are primarily metamorphosed andesites and dacites, rather than gabbros. These are pale green and some have veins of quartz or other minerals on or in them. Pyrite is abundant.

There are three types of breccia. One is a gray, semilithified mudstone containing coarse fragments of metamorphosed mafic igneous rock (Sample 58-1, Piece 8). The second is a dark green, friable breccia of altered mafic material of uniform color and appearance. The fragments in this breccia are 0.5 -to-1-cm angular chips. There are no feldspathic gabbro fragments in this type of breccia, unlike the typical matrix material of the upper polymict breccia. The third breccia type comprises indurated, pale green metavolcanic breccia (Sample 601, Piece 1). This appears to be a cemented and metamorphosed, fragmental version of the typical metavolcanic clasts in this interval. It is important to emphasize that none of the breccia types occurs in the upper polymict 
breccia, and that here metavolcanics far predominate over gabbros.

The upper polymict breccia contains many large gabbro clasts, and these appear to correlate with recovery (Fig. 8B). Had large clasts of any kind been in the lower polymict breccia, it seems likely that recovery would have been higher. Recovery in the last core of the upper polymict breccia (Core 57) was among the highest in that breccia, and there was no evidence for a decrease in bit diameter at that time. The drilling rate also accelerated with Core 58 . It seems likely, then, that the lower polymict breccia comprises predominantly soft breccias which fragmented during drilling. Rather than enter the core barrel, the small fragments were washed out by circulation.

The transition between the upper and lower polymict breccias was abrupt, in terms not only of recovery but also of breccia lithology. The matrix material in the lower part of Core 57 had the typical gray-red color of the upper polymict breccia. With Core 58 , breccias are highly chloritic and in this respect are similar to those of the green-matrix zone of the upper breccia. But they do not contain fragments of gabbro. It seems probable that the metamorphism in the lower polymict breccia was caused by the same hydrothermal event that altered the green breccia zone in the upper polymict breccia, since the metamorphic mineral assemblages are so similar (pyrite, chlorite, quartz, etc.).

\section{Sheared Mafic Gabbro (114-149.5 $\mathrm{m}$ below basement)}

Only a few fragments of metabreccia and pale green clay-a type of drilling slurry-were recovered in Core 62. The origin of this mud was obscure until retrieval of Core 63 , in which 1.5 meters of strongly sheared serpentinite and mafic gabbro were recovered. The outer cored surface of this material was coated with an identical soft green mud produced by the friction of drilling on the serpentine. Because of the possibility that the few fragments of metabreccia in Core 62 were fragments from the interval from 85.5 to 114 meters below the sediments (Cores 58-61) that fell down the hole, the transition between the lower polymict breccia and the serpentinite zone is placed at the base of Core 61 , above the "green mud" interval.

The material in Core 63 is dark gray-green and dark green gabbro with abundant pyrite. The gabbro is in small fragments (typically $1-5 \mathrm{~cm}$ ) stretched out along a primary rock foliation (Fig. 10). It is mafic to noritic, very dark gray in color, and makes up between 40 and 60 per cent of the rock (varying from place to place). Chloritic material is webbed between these fragments.

\section{PETROGRAPHY}

\section{Matrix}

The breccia's matrix consists of sand-sized fragments of various rock types and rock-forming minerals. The proportions of matrix and clastic material are variable. Matrix materials juxtaposed to large rock fragments are

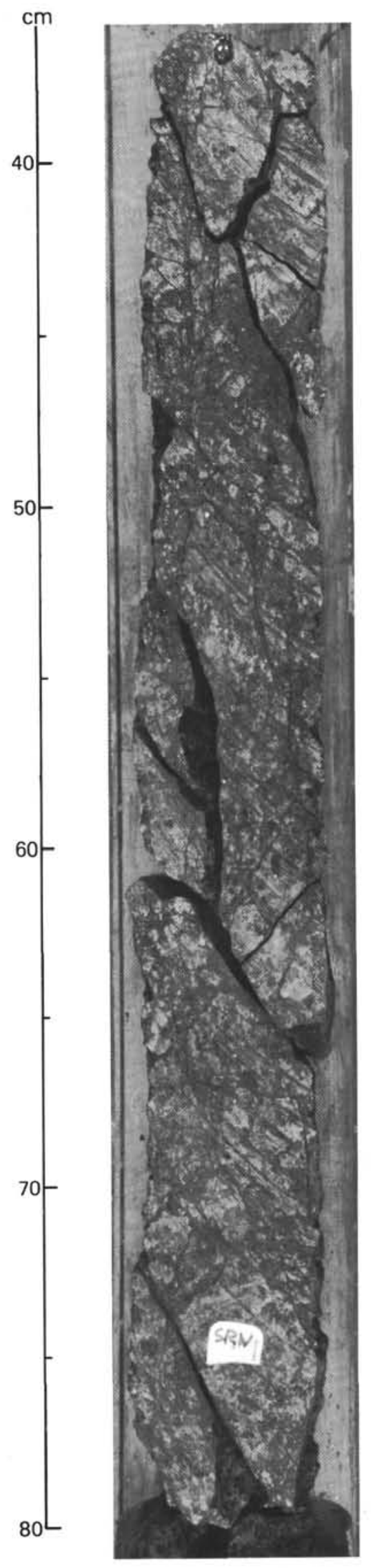

Figure 10. Section 63-1, showing serpentinized gabbro with fragments stretched out along the primary rock foliation. 
typically enriched in small rock clasts of the same composition (the best example is the matrix of Sample 53-3, $79-81 \mathrm{~cm}$. In general the matrix is heterogeneous.

The main components of the matrix are carbonate, chlorite, clay minerals, and iron oxides and hydroxides. Small amounts of epidote, quartz, prehnite, and pumpellyite are present in many cases. These minerals are variable in proportions and form granoblastic, sometimes lepidoblastic, textures in the matrix. Quartz, ironoxides, and carbonate are more abundant in the uppermost part of the breccia section and beneath the "greenmatrix zone." Within the green zone the matrix consists mainly of chlorite, zeolite, and epidote, and is enriched in clastic material.

It is interesting that in Sample 49-2, 64-66 cm, some rock fragments contain up to 70 per cent of andesinelabradorite plagioclase and could be andesitic in composition.

In thin section $54-1,31-33 \mathrm{~cm}$, one crystal in the matrix displays the optical properties of lawsonite. It is clastic in origin, indicating that one of the possible sources of the breccia matrix could be a high-pressure metamorphosed terrain.

Sample 49-1, 120-123 cm (Piece 8), consists of fine (0.3-to- $0.5-\mathrm{cm})$ carbonate grains $(70 \%$ by volume) and sparse altered rock fragments cemented by chlorite, clay, and iron-oxide. This sample seems to represent a portion of matrix that is almost free of clastic components.

\section{Basalts and Diabase}

Diabasic fragments are more abundant than basaltic ones in the breccia. Commonly aphyric or sometimes sparsely phyric, they contain 50 to 70 per cent plagioclase $\left(\mathrm{An}_{50-70}\right), 30$ to 50 per cent clinopyroxene, and accessory magnetite. Typical ground mass textures are ophitic or intersertal. Vesicles are rare (1-2\%), small $(0.2$ to $0.6 \mathrm{~mm})$, or totally absent. All of these rocks are moderately or severely altered, having variable amounts of chlorite, amphibole stilpnomelane, and iron oxides replacing clinopyroxene, and sericite, albite, and clay minerals replacing plagioclase.

In plagioclase or plagioclase-pyroxene phyric basalts the euhedral plagioclase phenocrysts $\left(\mathrm{An}_{55}, 0.5\right.$ to $5 \mathrm{~mm}$ in diameter) comprise up to 30 per cent of the rocks by volume. These, together with rare augite phenocrysts, are set in a subophitic or intersertal matrix formed by intergrown crystallites of the same minerals, plus minute opaques and some altered volcanic glass. A single olivine microphenocryst, altered to iddingsite, is present in thin section $54-3,106-109 \mathrm{~cm}$.

Alteration of the rocks is moderate to very high. In slightly or moderately altered rocks, chlorite and stilpnomelane replace the matrix and pyroxene grains, and sericite aggregates appear within the plagioclase grains. The metabasalts are amygdaloidal with chlorite, quartz, carbonate, and prehnite filling vesicles and vugs. These minerals also form the granoblastic groundmass together with pumpellyite, clay minerals, and iron hydroxides (see thin section 50-1, 52-56 cm).

\section{Gabbros}

The gabbros are the most abundant and most variable rock fragments of the breccia. Besides normal gabbros, anorthositic, pegmatitic, noritic, troctolitic, and hornblendic varieties are present. The original mineral assemblage includes plagioclase $\left(\mathrm{An}_{60-97}\right)$, clinopyroxene, orthophyroxene(?), olivine, and minor magnetite. One specimen of hornblende anorthositic gabbro (Sample $55-4,133-135 \mathrm{~cm}$ ) contains up to 10 per cent green spinel. Hypidiomorphic-granular, ophitic, poikilitic, and cumulus textures are typical of unmetamorphosed gabbros. In metamorphosed varieties granoblastic, nematoblastic, or foliated textures are observed.

Many gabbro fragments in the breccia contain secondary minerals typical of greenschist or amphibolite facies metamorphism. The most widespread is green hornblende. In thin section $55-4,133-135 \mathrm{~cm}$, it is bluish green and is more aluminous than usual. Chlorite, epidote, sericite, carbonate, clay minerals, accessory zeolite, prehnite, pumpellyite, and stilpnomelane are also present in many, especially in the highly altered gabbros. Core 63 of this site consists mostly of intensively sheared melanocratic and mylonitized gabbros, with abundant secondary green hornblende replacing cataclastic pyroxene grains, and traces of biotite.

\section{Tonalite}

One piece of foliated tonalite was found within the breccia fragments (Sample 55-3, 63-67 cm). The rock has lepidogranoblastic texture and consists of zoned oligoclase-albite, quartz, biotite, and minor K-feldspar with accessory magnetite, apatite, and zircon.

\section{CHEMISTRY OF IGNEOUS AND METAMORPHIC ROCKS}

Wood et al. (this volume) report analyses for 24 igneous and metamorphic rocks from the breccias of Site 453. Most of the rocks analyzed are gabbros, metagabbros, and pegmatitic gabbros showing clear evidence in their bulk chemistry of being cumulus rocks rich in either plagioclase or mafic phases. There is indeed a high abundance of mafic gabbros in Cores 55 through 57. Two samples analyzed from the upper polymict breccia are metabasalt. The two samples analyzed from the lower breccia are metamorphosed andesite and dacite. The sheared, serpentinized metagabbro from Core 63 has the composition of a mafic gabbro.

All of these rocks have the basic geochemical characteristics of arc magma types, with high $\mathrm{Sr}$ and $\mathrm{Ba}$ but low $\mathrm{Ti}, \mathrm{Cr}$, and $\mathrm{Ni}$ contents. One basalt (Sample 52-1, $30-36 \mathrm{~cm}$ ) has the composition of a primitive arc tholeiite. The high $\mathrm{Sr}$ and $\mathrm{Ba}$ contents of the plutonic rocks, in the view of Wood et al. (this volume), are "consistent with an origin in the deep-seated portion of an island arc." The high $\mathrm{Ba}$ and $\mathrm{Sr}$ in particular, and the somewhat high $\mathrm{K}_{2} \mathrm{O}$ of the biotite-bearing rocks, are certainly more typical of deep-seated arc rocks than gabbros found in exposed sections of ocean crust. This interpre- 
tation is complicated in a few rocks by marked enrichments in $\mathrm{K}_{2} \mathrm{O}$ and $\mathrm{Ba}$ from alteration processes. Nevertheless, the entire assemblage implies that the ridges surrounding Site 453 , from which the breccias must have come, are foundered portions of the West Mariana Ridge and are not truly a portion of the Mariana Trough.

\section{ALTERATION}

\section{Alteration and Metamorphism}

Differences in the secondary mineral assemblages observed in the matrix and clasts of the breccias suggest that many of the clasts were metamorphosed to lower greenschist or upper amphibolite facies before their incorporation into the breccia. Furthermore, many of the gabbroic clasts have tectonite fabrics that are generally not reflected in the adjacent matrix. This indicates a pre-breccia metamorphic history for many of the gabbros. The andesite and dacite of the lower polymict breccia also apparently had a pre-breccia metamorphic history, as evidenced by their bulk composition which is more albitized than the gabbros or metabasalts of the upper breccia.

The breccia matrix appears to have been subjected to lower-greenschist-facies metamorphic conditions. This is reflected primarily in the occurrence of chlorite, prehnite, and carbonate in the matrix. In the sections of breccia most affected by metamorphism, the original metamorphic mineralogy of the clasts appears to have retrograded to the lower greenschist facies of the matrix; and the breccia matrix is green, rather than brownish red.

The tentative identification of lawsonite in the matrix of a breccia fragment is intriguing and could have important implications for the origin of the breccia source material. The occurrence of abundant green spinel in several of the gabbro clasts studied in thin section is also noteworthy, since it has so rarely been reported in mafic plutonic rocks (e.g., Deer et al., 1964).

It is difficult at this stage to draw conclusions concerning the origin and history of the breccia and the serpentinite. However, it seems clear that the source areas for the breccia were metamorphosed prior to breccia formation. Based on the rock bulk analyses, the eastern slope of the West Mariana Ridge was the immediate source area. The metamorphism apparently occurred in the volcanic arc and predated the opening of the Mariana Trough.

The lower greenschist facies metamorphism of the breccia matrix may reflect interaction of parts of the breccia section with hydrothermal fluids originating from depths below the breccia. It is difficult to know whether these might be the same fluids which have reversed the $\mathrm{Mg}$ and $\mathrm{Ca}$ pore fluid gradients at the base of the sediments. Those fluids appear to have the composition of sea water (Gieskes and Johnson, this volume), but the hydrothermal alteration appears to have involved considerable transformation of calcic plagioclase to K-feldspar and occurred under high-temperature (resulting in the formation of chlorite), reducing conditions.

\section{Origin of the Breccias}

The origin of the sheared serpentinite is not clear at present. In Core 64 one rock was recovered-a sheared dark green rock with prominent plagioclase crystals. It could be a metamorphosed mafic gabbro or diabase. Whether it fell down the hole from above the sheared serpentinized gabbro of Core 63 or represents still another mafic breccia sequence cannot be resolved at present.

Any one of several hypotheses might explain the breccia sequence. The simplest is that the upper breccia, the lower breccia, and the serpentinized gabbro each represents separate, chaotically slumped masses from sources of restricted composition. The local concentration of mafic gabbros and diabase in the upper polymict breccia would be basically random in origin, only the overall source for the upper breccias was more heterogeneous. It is also probable that the gabbros came from sources closer than the basalts, as evidenced by their greater abundance and large clast size. This could indicate that the basalts might have been derived from higher up on the same fault block, or that the access of basaltic debris to the bottom of the sediment pond was restricted by benches. The location of the breccias in the center of the sediment pond and their low angle of repose (see section on Geophysics, this chapter) suggest they might be flat-lying slump or avalanche debris rather than talus.

An alternative emplacement hypothesis is that only the upper polymict breccia is a slump or avalanche deposit. The lower breccias and sheared mafic gabbro could be a part of a fault zone. The hypothesis, then, links the occurrence of sheared rocks with zones of hydrothermal alteration and with lithologic changes. It is tempting to speculate that the hydrothermal zone in the upper polymict breccias, as well as the hydrothermally altered pyritized greenstones of the lower polymict breccias, formed in zones of shear that were conduits for hydrothermal solutions. Displacement along the shear zone juxtaposed breccias of different igneous and metamorphic rock populations, and of different clast size. The sheared mafic gabbro is the principal evidence for the lower shear zone. Fractured gabbros in the green breccia zone of the upper polymict breccia might be evidence for shear there as well.

A third hypothesis would have the sheared gabbro alone part of a fault zone. The breccias above would have been shed from a block of crust that was gradually faulted relatively upward, exposing deeper and more coarsely crystalline mafic rock assemblages. Thus the lower polymict breccia would consist mainly of metavolcanics derived from the upper part of the fault block before deeper gabbros were exposed. The upper breccia would contain mostly gabbros, with fewer basalts and diabases.

\section{PALEOMAGNETICS}

Paleomagnetic measurements were made in 34 sediment samples and 22 igneous and metamorphic rock samples from the breccia zones (Bleil, this volume). The variation of magnetic inclination with depth and the 
paleontological information in the lower sediment layer fit approximately with the current geomagnetic polarity time scales. This fit gives an age of about 5.0 \pm 0.2 m.y. for the base of the sediment. The magnetic inclination of sediments, however, is too shallow for the present location of the site (mean stable inclination $=15.0^{\circ} \pm$ $10.0^{\circ}$, as against the present inclination of the Earth's field at this latitude of about $\left.+35^{\circ}\right)$. Rocks from the breccia zone show a stable inclination of $36.4^{\circ} \pm 20.3^{\circ}$, which agrees with the present inclination. The origin of the remanent magnetization remains unclear. For more details, see Bleil (this volume).

\section{PHYSICAL PROPERTIES}

Compressional wave velocity, wet-bulk density, saltcorrected water content, porosity, acoustic impedance, and thermal conductivity were determined for cores recovered from Site 453. The measurements are tabulated in Table 2.

\section{Sonic Velocities}

Sonic velocities were measured on the Hamilton Frame. With the exception of one sample, which was checked for anisotropy, measurements were made only for the vertical direction. Many of the sedimentary rock samples obtained from depths greater than 120 meters below the sea floor cleaved easily along bedding planes, making it easy to produce a parallel-sided slab suitable for placing in the Hamilton Frame. Further trimming or sawing of such samples to measure velocities parallel to the bedding planes would in most cases have resulted in their disintegration. Compressional wave velocity in the sediment ranged from 1.50 to $2.45 \mathrm{~km} / \mathrm{s}$. In the breccia underlying the sediment the mean seismic velocity of 12 samples was $4.75 \mathrm{~km} / \mathrm{s}$, but three gabbro samples from within the breccia had much higher velocities (6.57 to $6.82 \mathrm{~km} / \mathrm{s}$ ). The tectonized serpentinite at the bottom of the hole had highly variable seismic velocities, ranging from 4.21 to $6.10 \mathrm{~km} / \mathrm{s}$, probably depending on the amount of shearing within the samples.

\section{Wet-Bulk Density, Water Content, Porosity}

A proportion of the sonic velocity samples were subjected to GRAPE special 2-Minute counts for the determination of wet-bulk density. The wet-bulk density, water content, and porosity of the greater number of these same samples were then determined by gravimetric methods. During drilling at this site the GRAPE machine underwent major servicing, including the installation of a new scintillation tube. This resulted in a $7 \%$ per cent change in the attenuation coefficient obtained with the 5-cm-thick quartz standard, and a doubling of the air count. The change occurred between Cores 28 and 29 as far as the 2 -minute observations are concerned. However, as the comparison of the two methods of measuring density indicates (Fig. 11), no systematic error resulted. The slightly large discrepancies obtained between the two methods at the higher end of the density scale is thought to be due to the igneous rock samples (particularly the breccia) being inherently more inhomogeneous on the scale of the gamma-ray beam (about the thickness of a pencil) than the sedimentary samples.

The wet-bulk densities of the sedimentary rocks range from 1.2 to $1.9 \mathrm{~g} / \mathrm{cm}^{3}$. One sample (from Section 29-1) yielded a gravimetric determination of $2.03 \mathrm{~g} / \mathrm{cm}^{3}$ and a GRAPE value of $1.50 \mathrm{~g} / \mathrm{cm}^{3}$. This was the only major discrepancy between the two methods (too large to show on Fig. 11). The higher density is probably in error.

The igneous rocks had much higher densities, averaging $2.55 \mathrm{~g} / \mathrm{cm}^{3}$ for 12 breccia samples, $2.92 \mathrm{~g} / \mathrm{cm}^{3}$ for three gabbros, $2.93 \mathrm{~g} / \mathrm{cm}^{3}$ for three serpentinites, and $2.63 \mathrm{~g} / \mathrm{cm}^{3}$ for a gabbro pegmatite.

\section{Variation of Velocity-Density Parameters with Depth}

Sonic velocity, wet-bulk density, and acoustic impedance for the sedimentary sequence are plotted against depth below the sea bed in Figure 12. In general all three parameters increase with depth, although much smallscale variation-particularly in sonic velocity-is apparent. It is important to emphasize that most of this scatter is real, not the result of measurement errors, and is generated by beds with different properties alternating in the sedimentary sequence, often within the same core or section of a core. In an attempt to relate these measurements to the seismic reflection profile, two broad-scale discontinuities have been identified at 120 meters and 290 meters below bottom. These two discontinuities divide the sedimentary column into three layers whose average properties are summarized in Table 3. In terms of the measured samples themselves, the three layers correspond to:

(1) muds and clays soft enough for samples to be scooped from the cores;

(2) mudstones and claystones cleaving easily along bedding planes to produce parallel-sided samples; and

(3) same mudstones and claystones as (2), but which required sawing to prepare a sample for the Hamilton Frame.

The normal reflection coefficient and two-way travel time from the sea bed have been calculated for each discontinuity and are given in Table 3 . The correlation between the calculated reflection times and the seismic reflection record is shown in Figure 13. The reflection coefficients increase down the column, but none is large until the sediment/breccia interface is reached. The fact that this does not show up more clearly on the reflection record may be due to the probable rough surface of breccia rubble layer.

Sonic velocity and porosity measurements for the breccia samples are plotted against depth in Figure 14. Both show consistent and compatible trends, with velocity increasing and the porosity decreasing with depth.

\section{Thermal Conductivity}

Thermal conductivities of core samples recovered at Site 453 were measured, and a profile of thermal conductivity of the uppermost oceanic crust constructed 
Table 2. Physical properties measurements, Hole 453.

\begin{tabular}{|c|c|c|c|c|c|c|}
\hline $\begin{array}{c}\text { Sample } \\
\text { (interval in } \mathrm{cm} \text { ) }\end{array}$ & $\begin{array}{l}\text { Depth } \\
\text { (m) }\end{array}$ & $\begin{array}{c}\text { Sound } \\
\text { Velocity } \\
\text { (vertical) } \\
(\mathrm{km} / \mathrm{s})\end{array}$ & $\begin{array}{l}\text { GRAPE 2-min. } \\
\text { Wer-Bulk } \\
\text { Density } \\
\left(\mathrm{g} / \mathrm{cm}^{3}\right)\end{array}$ & $\begin{array}{l}\text { Wet Water } \\
\text { Content } \\
\text { (salt } \\
\text { corrected) } \\
(\%)\end{array}$ & $\begin{array}{c}\text { Porositya } \\
(0 \%)\end{array}$ & $\begin{array}{l}\text { Wet-Bulk }{ }^{\mathrm{b}} \\
\text { Density } \\
\left(\mathrm{g} / \mathrm{cm}^{3}\right)\end{array}$ \\
\hline $1-2,100-102$ & 2.50 & 1.52 & & 73.7 & 87.9 & 1.22 \\
\hline $1-3,80-82$ & 3.80 & 1.52 & & & & \\
\hline $1-4,114-116$ & 5.64 & 1.51 & & & & \\
\hline $1-5,100-102$ & 7.00 & 1.50 & & 68.8 & 85.4 & 1.27 \\
\hline $1-6,3-5$ & 7.53 & 1.52 & & & & \\
\hline $2-1,100-102$ & 10.0 & 1.51 & & & & \\
\hline $2-2,80-82$ & 12.30 & 1.51 & & 66.2 & 83.8 & 1.30 \\
\hline $2-3,85-87$ & 12.85 & 1.51 & & 57.0 & 77.9 & 1.40 \\
\hline $2-4,10-12$ & 13.60 & 1.52 & & 47.0 & 70.5 & 1.54 \\
\hline $3-1$ & 18.5 & 1.51 & & & & \\
\hline $3-2,45-47$ & 20.45 & 1.50 & & 63.4 & 82.1 & 1.33 \\
\hline $4-2,105-107$ & 30.55 & 1.54 & & 74.8 & 88.7 & 1.22 \\
\hline $4-3,100-102$ & 32.0 & 1.53 & & & & \\
\hline $4-4,100-102$ & 33.50 & 1.53 & & 76.3 & 89.8 & 1.21 \\
\hline $4-5,60-62$ & 34.60 & 1.53 & & & & \\
\hline $4-6,30-32$ & 35.80 & 1.57 & & & & \\
\hline $5-1,75-77$ & 38.25 & 1.54 & & 75.0 & 89.2 & 1.22 \\
\hline $5-2,35-37$ & 39.35 & 1.56 & & & & \\
\hline $6-1,100-102$ & 48.0 & 1.58 & & 74.6 & 88.9 & 1.22 \\
\hline $8-1,40-42$ & 66.40 & 1.55 & & & & \\
\hline $8-1,132-134$ & 67.32 & 1.57 & & & & \\
\hline $8-2,40-42$ & 67.90 & 1.55 & & 73.4 & 88.5 & 1.23 \\
\hline $8-3,80-82$ & 69.80 & 1.55 & & 76.3 & 90.0 & 1.21 \\
\hline $8-4,90-92$ & 71.40 & 1.56 & & & & \\
\hline $9-1,21-23$ & 75.71 & 1.62 & & 54.9 & 76.8 & 1.43 \\
\hline $10-2,100-102$ & 87.5 & 1.56 & & 75.3 & 89.3 & 1.21 \\
\hline $10-3,13-15$ & 88.13 & 1.62 & & & & \\
\hline $11-1,43-45$ & 94.93 & 1.55 & & 74.0 & 88.6 & 1.23 \\
\hline $11-2,43-45$ & 96.43 & 1.78 & & 50.9 & 72.3 & 1.45 \\
\hline $11-3,60-62$ & 98.10 & 1.51 & & & & \\
\hline $11-4,43-45$ & 99.43 & 1.52 & & 69.7 & 86.6 & 1.27 \\
\hline $11-5,43-45$ & 100.93 & 1.56 & & 63.3 & 82.5 & 1.33 \\
\hline $11-6,43-45$ & 102.43 & 1.55 & & 68.5 & 85.8 & 1.28 \\
\hline $13-1,83-85$ & 114.33 & 1.54 & & 52.8 & 74.0 & 1.43 \\
\hline $14-1,46-48$ & 123.46 & 1.62 & & & & \\
\hline $14-2,76-78$ & 125.26 & 1.79 & & 57.5 & 77.3 & 1.38 \\
\hline $14, \mathrm{CC}$ & 126.0 & 1.92 & & & & \\
\hline $15-1,63-65$ & 133.13 & 1.79 & 1.31 & & & \\
\hline $15-2,29-31$ & 134.29 & 1.75 & 1.36 & 60.7 & 80.5 & 1.36 \\
\hline $17-1,46-48$ & 151.96 & 1.86 & 1.37 & 57.9 & 78.2 & 1.38 \\
\hline $18-1,103-105$ & 162.03 & 1.72 & 1.40 & 51.5 & 72.7 & 1.45 \\
\hline $18-5, \quad 137-139$ & 168.37 & 1.83 & 1.50 & 52.0 & 73.6 & 1.45 \\
\hline $19-1,28-30$ & 170.78 & 1.63 & & & & \\
\hline $20-1,140-142$ & 181.40 & 1.61 & 1.31 & 66.7 & 84.4 & 1.30 \\
\hline $20-2,40-43$ & 181.90 & 1.63 & & & & \\
\hline $21-1,120-122$ & 190.70 & 1.81 & 1.31 & 66.6 & 83.6 & 1.28 \\
\hline $21-2,13-15$ & 191.13 & 1.74 & & & & \\
\hline $22-1,148-150$ & 200.48 & 1.83 & 1.43 & 50.0 & 71.1 & 1.46 \\
\hline $22-2,63-65$ & 201.13 & 1.80 & & & & \\
\hline $23-1,105-107$ & 209.55 & 1.73 & 1.41 & 55.0 & 75.3 & 1.40 \\
\hline $24-1,102-104$ & 219.02 & 1.73 & & 49.5 & 70.3 & 1.45 \\
\hline $24-1,140-143$ & 219.40 & 1.68 & & & & \\
\hline $24-2,72-74$ & 220.22 & 1.63 & & 53.3 & 73.0 & 1.40 \\
\hline $24-2,141-144$ & 220.91 & 1.68 & & & & \\
\hline $25-1,49-51$ & 227.99 & 1.67 & & & & \\
\hline $26-1,49-51$ & 237.49 & 1.62 & & 50.1 & 71.1 & 1.45 \\
\hline $27-1,8-10$ & 246.58 & 1.74 & 1.49 & 45.9 & 67.4 & 1.51 \\
\hline $27-1,130-132$ & 247.8 & 1.76 & & & & \\
\hline $27-2,108-110$ & 249.09 & 1.71 & & & & \\
\hline $28-1,5-7$ & 256.05 & 1.64 & 1.45 & 50.6 & 70.9 & 1.43 \\
\hline $28-2,29-31$ & 257.79 & 1.66 & & & & \\
\hline $29-1,21-22$ & 265.71 & 1.99 & & & & \\
\hline $29-1,89-91$ & 266.39 & 2.06 & 1.50 & 20.4 & 40.4 & 2.03 \\
\hline $29-2,33-34$ & 267.33 & 2.00 & & & & \\
\hline $29-3,32-34$ & 268.82 & 2.43 & & & & \\
\hline $29-4,52-55$ & 270.52 & 1.93 & & & & \\
\hline $30-1,103-105$ & 276.03 & 1.68 & & 49.8 & 70.4 & 1.45 \\
\hline $31-2,68-70$ & 286.68 & 1.76 & 1.53 & 48.2 & 69.5 & 1.48 \\
\hline $32-1,125-127$ & 295.25 & 2.16 & 1.64 & 43.3 & 67.3 & 1.59 \\
\hline $32-2,38-40$ & 295.88 & 1.98 & & & & \\
\hline $32-3,70-72$ & 297.70 & 1.97 & & & & \\
\hline $33-1,70-72$ & 304.20 & 1.95 & 1.52 & 44.5 & 66.4 & 1.53 \\
\hline $33-2,30-34$ & 305.30 & 2.09 & & & & \\
\hline $33-3,110-112$ & 207.60 & 2.14 & & & & \\
\hline $34-1,72-74$ & 313.72 & 2.33 & 1.62 & 41.7 & 65.7 & 1.61 \\
\hline $34-2,116-119$ & 315.66 & 2.15 & & & & \\
\hline $34-3,89-91$ & 316.89 & 2.03 & & & & \\
\hline $35-1,109-112$ & 323.59 & 2.02 & & & & \\
\hline $35-2,4-6$ & 324.04 & 2.02 & 1.63 & 42.1 & 66.6 & 1.62 \\
\hline $35-3,86-88$ & 326.36 & 2.19 & & & & \\
\hline $36-1,72-74$ & 332.72 & 1.70 & & & & \\
\hline $36-2,82-84$ & 334,32 & 1.68 & 1.40 & 59.2 & 79.6 & 1.38 \\
\hline $36-3,106-108$ & 336.06 & 1.97 & & & & \\
\hline $36-4,113-119$ & 337.63 & 1.98 & & & & \\
\hline $36-5,73-74$ & 338.73 & 2.39 & 1.90 & 29.6 & 53.7 & 1.86 \\
\hline $37-1,37-42$ & 341.87 & 1.95 & & & & \\
\hline $37-2,20-22$ & 343.20 & 2.17 & 1.73 & 36.5 & 60.6 & 1.70 \\
\hline $37-4,55-59$ & 346.55 & 2.25 & & & & \\
\hline $38-1,100-103$ & 352.00 & 2.09 & & & & \\
\hline $38-2,54-56$ & 353.04 & 2.01 & & 41.8 & 66.3 & 1.62 \\
\hline $39-1,72-75$ & 361,22 & 2.10 & 1.60 & 43.9 & 68.0 & 1.59 \\
\hline
\end{tabular}


Table 2. (Continued).

\begin{tabular}{|c|c|c|c|c|c|c|c|c|}
\hline $\begin{array}{l}\text { Sample } \\
\text { (interval in } \mathrm{cm} \text { ) }\end{array}$ & $\begin{array}{l}\text { Depth } \\
\text { (m) }\end{array}$ & $\begin{array}{c}\text { Sound } \\
\text { Velocity } \\
\text { (vertical) } \\
(\mathrm{km} / \mathrm{s})\end{array}$ & $\begin{array}{l}\text { GRAPE 2-min. } \\
\text { Wet-Bulk } \\
\text { Density } \\
\left(\mathrm{g} / \mathrm{cm}^{3}\right)\end{array}$ & $\begin{array}{l}\text { Wet Water } \\
\text { Content } \\
\text { (salt } \\
\text { corrected) } \\
(\%)\end{array}$ & $\begin{array}{l}\text { Porositya } \\
\qquad\left(\omega_{0}\right)\end{array}$ & $\begin{array}{l}\text { Wet Bulk }{ }^{b} \\
\text { Density } \\
\left(\mathrm{g} / \mathrm{cm}^{3}\right)\end{array}$ & $\begin{array}{c}\text { Acoustic } \\
\text { Impedance } \\
\left(\mathrm{g} / \mathrm{cm}^{2} \mathrm{~s} \times 10^{5}\right)\end{array}$ & Rock Type \\
\hline $39-2,30-33$ & 362.30 & 2.12 & & & & & & Claystone \\
\hline $39-4,54-56$ & 365.54 & 1.91 & & & & & & Mudstone \\
\hline $40-1,72-74$ & 379.72 & 1.90 & & & & & & Mudstone \\
\hline $40-2,98-100$ & 372.48 & 1.93 & 1.49 & 43.9 & 65.4 & 1.53 & 2.95 & Mudstone \\
\hline $40-4,52-55$ & 375.02 & 1.90 & . & & & & & Siltstone \\
\hline $41-2,81-83$ & 381.81 & 2.19 & & & & & & Mudstone \\
\hline $42-1,105-108$ & 390.05 & 2.22 & & & & & & Mudstone \\
\hline $42-2,52-55$ & 391.02 & 2.26 & 1.67 & 38.4 & 62.7 & 1.67 & 3.77 & Mudstone \\
\hline $43-3,30-32$ & 401.80 & 2.26 & 1.68 & 39.6 & 64.2 & 1.66 & 3.75 & Mudstone \\
\hline $44-1,36-38$ & 408.36 & 2.24 & 1.59 & 41.3 & 63.8 & 1.58 & 3.54 & Mudstone \\
\hline $44-2,23-26$ & 409.73 & 2.22 & & & & & & Mudstone \\
\hline $45-1,45-47$ & 417.95 & 2.42 & 1.62 & 37.5 & 61.6 & 1.67 & 4.04 & Mudstone \\
\hline $45-2,106-108$ & 420.06 & 2.45 & & & & & & Siltstone \\
\hline $45-4,50-52$ & 422.50 & $2.56 \mathrm{~V}$ & & & & & & Mudstone \\
\hline $45-4,50-52$ & 422.50 & $2.60 \mathrm{H}$ & & & & & & Mudstone \\
\hline $46-1,14-16$ & 427.14 & 2.14 & 1.70 & 38.4 & 62.5 & 1.67 & 3,57 & Claystone \\
\hline $47-1,29-31$ & 436.79 & 2.19 & 1.80 & 34.5 & 59.0 & 1.75 & 3.83 & Claystone \\
\hline $47-3,32-34$ & 439.82 & 2.17 & & & & & & Siltstone \\
\hline $48-1,21-23$ & 446.21 & 2.29 & 1.93 & 27.3 & 50.2 & 1.88 & 4.31 & Very fine sandstone \\
\hline $49-1,77-80$ & 456.27 & 5.52 & 2.83 & 1.9 & 5.1 & 2.83 & 15.6 & Basalt \\
\hline $49-1,98-100$ & 456.48 & 6.73 & 2.87 & 0.9 & 2.6 & 2.87 & 19.3 & Gabbro \\
\hline $49-1,113-114$ & 456.63 & 5.70 & 2.83 & 1.1 & 3.1 & 2.81 & 16.0 & Metabasalt \\
\hline $49-1,118-126$ & 456.68 & 2.37 & & & & & & Sandstone \\
\hline $49-2,4 i-42$ & 457.41 & 4.41 & 2.37 & 6.3 & 15.2 & 2.46 & 10.8 & Breccia \\
\hline $49-2,105-107$ & 458.05 & 4.07 & 2.41 & 5.6 & 13.8 & 2.51 & 10.2 & Breccia \\
\hline $50-1,42-44$ & 465.42 & 5.96 & 2.83 & 0.7 & 1.9 & 2.82 & 16.8 & Altered basalt \\
\hline $50-1,107-109$ & 466.07 & 5.70 & 2.60 & 3.1 & 8.1 & 2.66 & 15.2 & Gabbro \\
\hline $51-1,5-7$ & 474.55 & 6.82 & 2.80 & 0.3 & 0.8 & 2.88 & 19.6 & Gabbro \\
\hline $51-2,11-13$ & 476.11 & 4.70 & 2.77 & 5.0 & 12.7 & 2.59 & 12.2 & Breccia \\
\hline $51-3,19-25$ & 477.69 & 4.77 & 2.46 & & & & & Breecia \\
\hline $52-1,12-126$ & 485.20 & 4.36 & 2.67 & & & & & Breccia \\
\hline $53-1,33-34$ & 493.83 & 4.84 & 2.58 & 4.6 & 11.3 & 2.53 & 12.2 & Breccia \\
\hline $53-3,24-26$ & 496.74 & 6.57 & 3.01 & 0.3 & 1.0 & 3.04 & 20.0 & Gabbro \\
\hline $53-5,123-126$ & 500.73 & 4.75 & 2.50 & 4.2 & 10.5 & 2.54 & 12.1 & Breccia \\
\hline $54-1,24-31$ & 503.24 & 4.71 & 2.64 & & & & & Breccia \\
\hline $55-3,2-8$ & 515.52 & 5.01 & 2.60 & & & & & Breccia \\
\hline $56-1,38-40$ & 522.38 & 4.15 & 2.58 & 4.2 & 10.4 & 2.56 & 10.6 & Breccia \\
\hline $57-1,123-125$ & 532.73 & 5.40 & 2.48 & 3.1 & 7.5 & 2.48 & 13.4 & Breccia \\
\hline $57-2,108-113$ & 534.08 & 5.78 & 2.73 & & & & & Breccia \\
\hline $63-1,25-27$ & 588.75 & 4.21 & 2.86 & 4.4 & 12.2 & 2.82 & 11.9 & Serpentinite \\
\hline $63-1,121-123$ & 589.71 & 6.10 & 3.13 & 1.8 & 5.3 & 3.05 & 18.6 & Serpentinite \\
\hline $63-1,127-130$ & 589.77 & 5.19 & 2.77 & & & & & Serpentinite \\
\hline
\end{tabular}

a Porosity $=$ salt corrected wet water content $\times$ wet-bulk density (gravimetric)/1.025.

b Gravimetric method.

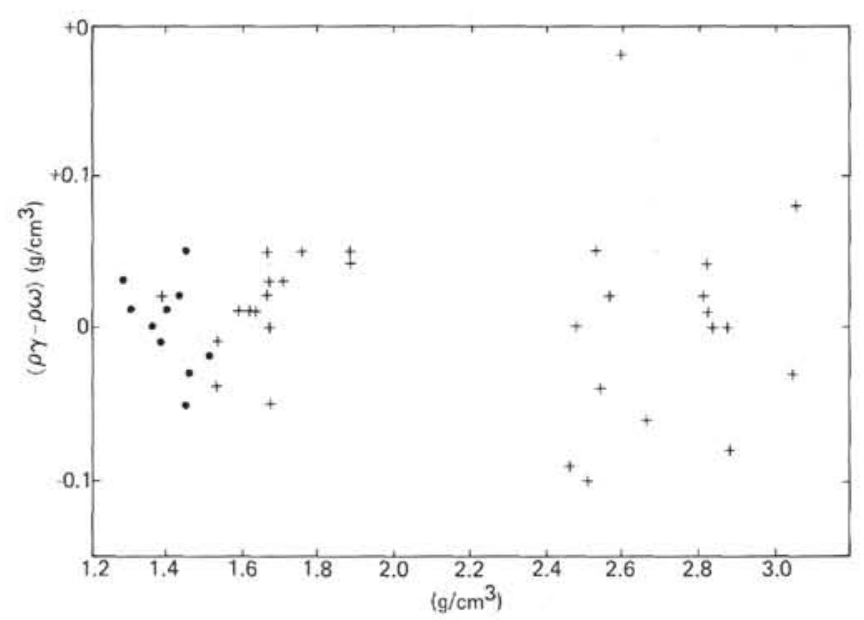

Figure 11. Comparison of GRAPE (@ GRAPE) (2-minute) and gravimetric $\left(\varrho_{b}\right)$ determinations of wet-bulk density. Solid circles are determinations of Cores 15 through 28 ; crosses are Cores 29 through 68 .

(Horai, this volume). The results show a thermal conductivity monotonically increasing with depth through the entire sedimentary section. The rate of increase is $0.23 \mathrm{mcal} / \mathrm{cm} \mathrm{s}{ }^{\circ} \mathrm{C} / 100$ meters. There is no clear relationship between thermal conductivity and depth in the breccia sequence which extended from the depth of 450 meters downward. Details are given in Horai (this volume).

\section{GEOPHYSICS}

After drilling at Site 452, the easternmost of the Leg 60 drill sites, the Glomar Challenger traversed all the other SP1 through SP4 targets on the way to Site 453, the westernmost drill site. The reflection seismic profile along this track is described by Hussong (this volume). The Challenger then made one pass over the sediment pond target for $\mathrm{SP}-4 \mathrm{~F}$, and returned and dropped the beacon.

A generalized isopach map of the SP-4F sediment pond in which Hole 453 was drilled was prepared from the ship's tracks approaching and departing the site, supplemented by an L-DGO and two H.I.G. tracks in the area. The map (Fig. 15) shows the pond to be elongated north-northeast-south-southwest, 3-5 km wide, and at least $20 \mathrm{~km}$ long. It is flanked by irregular ridges rising only about 400 meters above the pond on the west and 200 meters on the east. Although the northeastern end of the pond was not crossed by any tracks available to this report, a track along $18^{\circ} \mathrm{N}$ latitude does not intersect the pond. The sediment thickness in the pond also decreases markedly to the northeast.

The southwest end of the pond is also poorly defined. An east-west H.I.G. track along $17^{\circ} 48^{\prime} \mathrm{N}$ shows the 


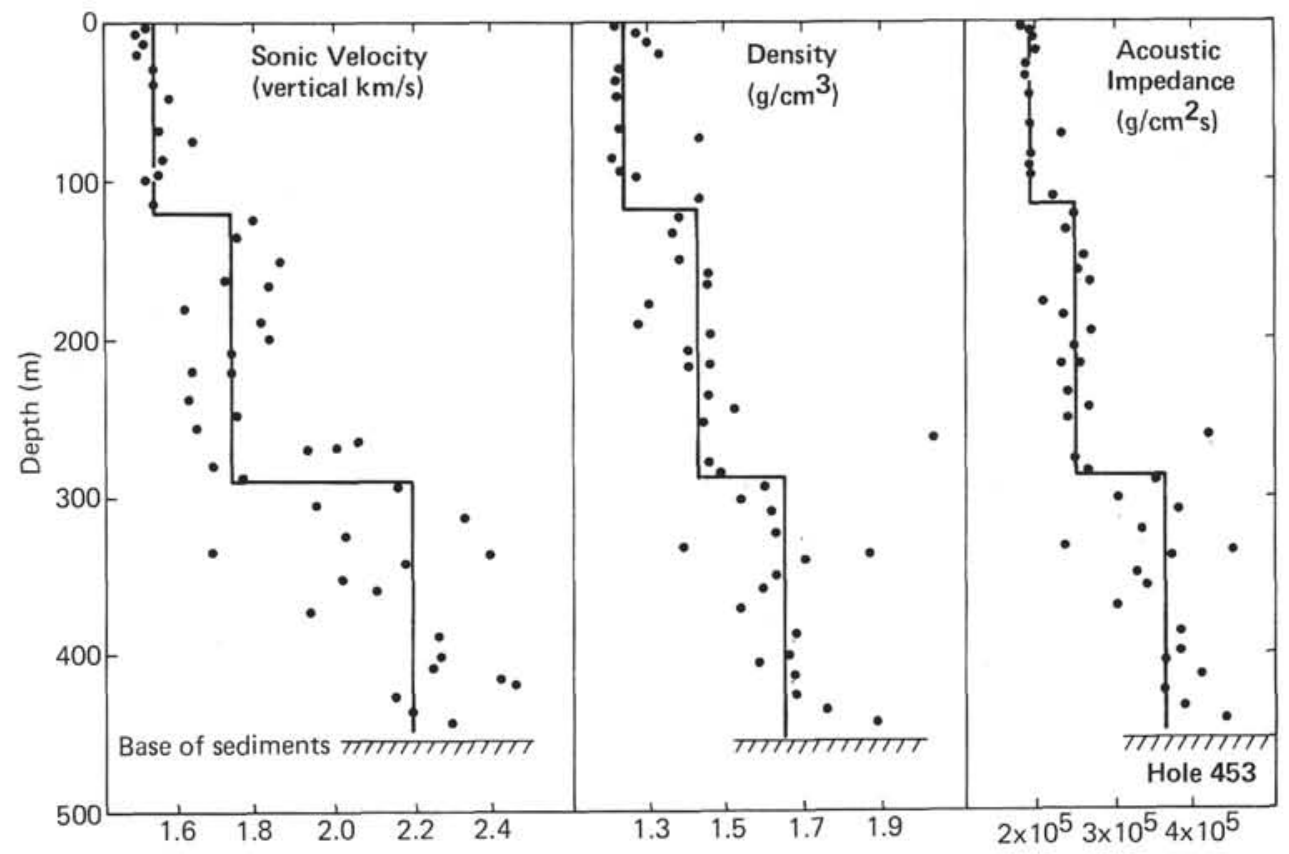

Figure 12. Shipboard density and sonic velocity measurements of Hole 453 sediment core samples used to calculate the acoustic impedance with depth.

Table 3. Summary of velocity-density parameters, Hole 453.

\begin{tabular}{|c|c|c|c|c|c|c|}
\hline Interval & $\begin{array}{l}\text { Sonic } \\
\text { Velocity } \\
(\mathrm{km} / \mathrm{s})\end{array}$ & $\begin{array}{l}\text { Wet-Bulk } \\
\text { Density } \\
\left(\mathrm{g} / \mathrm{cm}^{3}\right)\end{array}$ & $\begin{array}{c}\text { Acoustic } \\
\text { Impedance } \\
\left(10^{5} \mathrm{~g} / \mathrm{cm}^{2} \mathrm{~s}\right)\end{array}$ & $\begin{array}{l}\text { Two-Way Travel } \\
\text { Time }^{\text {a }} \\
\text { (millisecond) }\end{array}$ & $\begin{array}{l}\text { Normal Reflection } \\
\text { Coefficient at } \\
\text { Base of Layer }\end{array}$ & $\begin{array}{l}\text { Predominant } \\
\text { Rock Types }\end{array}$ \\
\hline $\begin{array}{l}\text { Sea water } \\
\text { near bottom }\end{array}$ & $1.54^{\mathrm{b}}$ & 1.03 & 1.59 & 0 & 0.09 & \\
\hline $0-120 \mathrm{~m}$ & 1.54 & 1.24 & 1.91 & 156 & 0.13 & \multirow{4}{*}{$\begin{array}{l}\text { Mud, clay } \\
\text { Mudstone, } \\
\text { claystone } \\
\text { Mudstone, } \\
\text { claystone } \\
\text { Igneous rock } \\
\text { breccia }\end{array}$} \\
\hline $120-290 \mathrm{~m}$ & 1.73 & 1.42 & 2.46 & 352 & 0.19 & \\
\hline $290-455 \mathrm{~m}$ & 2.19 & 1.64 & 3.59 & 503 & 0.54 & \\
\hline $455-\quad m$ & 4.75 & 2.55 & 12.1 & & & \\
\hline
\end{tabular}

${ }^{a}$ From sea bed to base of layer

Interpolated from Matthews Tables, Area 42, for a depth of 4693 meters.

sediment pond at the same water depth, but this far south, it is disrupted by large, high-angle faults. This profile is not used in Figure 15. Another Hawaii Institute of Geophysics track, at about $17^{\circ} 46^{\prime} \mathrm{N}$, did not intersect the pond.

A cross-section of the pond, through the drill site and along the ship's track, labeled A-B in Figure 15, is presented as Figure 16. This is a true-scale (no vertical exaggeration) depth section based on the reflection times obtained by the Challenger during the crossing of the pond on 0301-0346 28 March (Fig. 13) and velocities of drilled samples as measured aboard ship. The thickness of the sediment layer and depth to the top of the gabbro/breccia are well controlled by the profiling data and the drilling. The depth to basement is calculated from less distinct reflectors and should be considered only a good approximation.

Figure 17 also shows the reflection record from which the pond section is derived. It is interesting that in the adjacent pond to the east, sub-bottom reflectors in the sediment have similar character and depth to those observed at Site 453 , suggesting that the sediment char- acter and sedimentation process found in Hole 453 may extend to adjacent ponds.

When the gabbro/breccia material was first sampled at Site 453, the initial shipboard evaluation was that we had penetrated a talus slope. However, if we assume that the reflector which correlates with the top of the breccia is continuous across the pond, as is apparent on the reflection record, then the scale drawing (Fig. 16) of the Site 453 pond shows the relatively flat upper surface and large volume of the gabbro/breccia material in the pond, particularly when compared to the relative smallness of the ridges surrounding the ponds. It is difficult to consider the ridges as the source of the disturbed crystalline rock in the bottom of the pond when looking at the slopes and transport distances without benefit of vertical exaggeration. Furthermore, the presence of the $4.75-\mathrm{km} / \mathrm{s}$ layer throughout the pond, rather than only at its periphery, suggests that the rock fragments comprising it were fractured and deposited essentially in situ.

A possible source of the breccia rubble might be crustal faulting that could also be responsible for the 


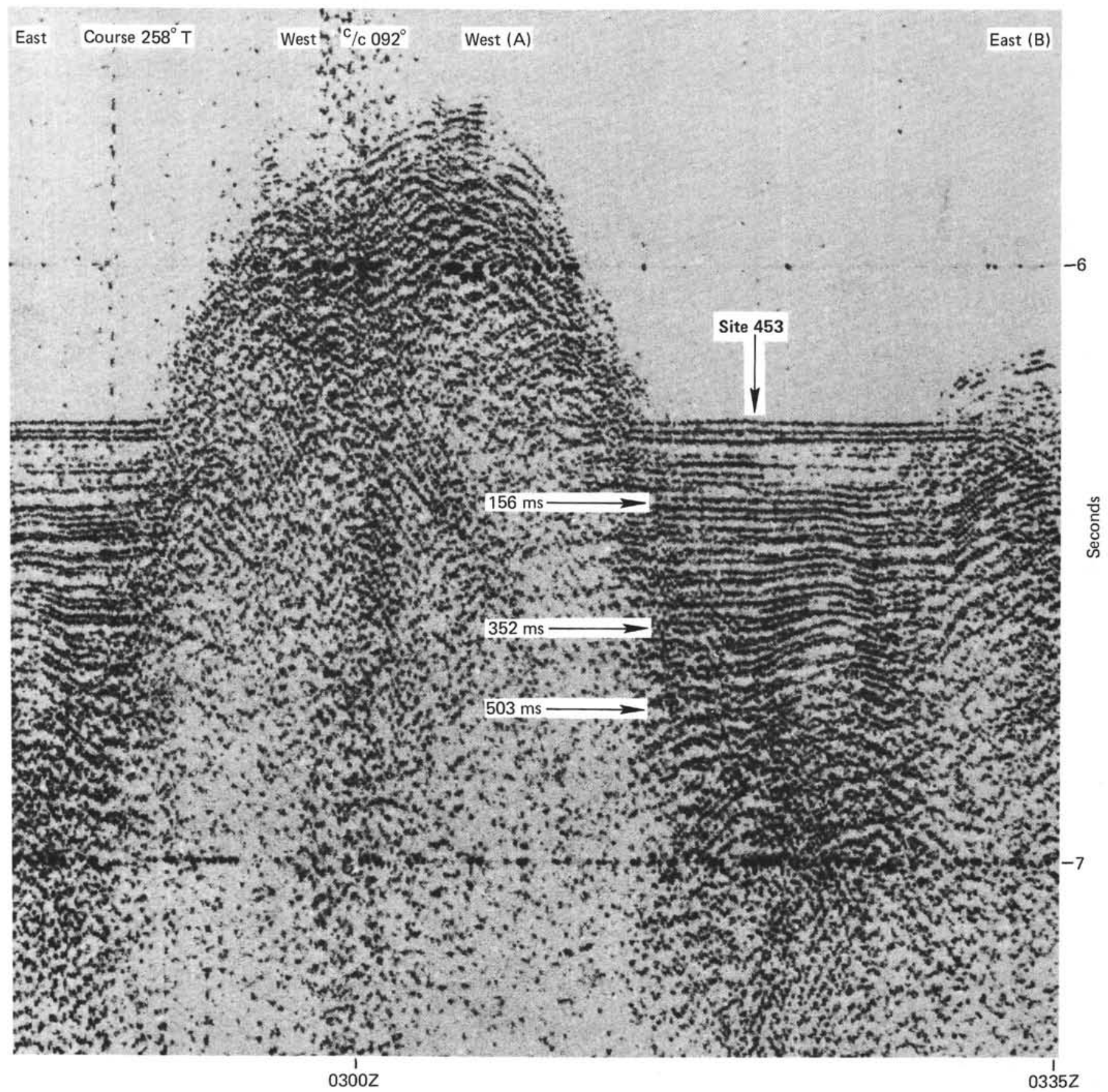

Figure 13. Low frequency (120-cu. in. airgun source) reflection record across the pond at Site 453 . The sediment pond at the left is the western side of the same pond before the Challenger reversed its course and made the second crossing (west to east; labeled A to B). The reflectors labeled by their two-way seismic travel times beneath the sea floor correspond to the calculated major change in acoustic impedance observed in the core samples (Fig. 12).

elongate north-northeast-south-southwest orientation of the Site 453 sediment pond. This possibility is given more likelihood by the post-cruise determinations that the polymict breccia and the underlying meta-igneous rocks are apparently derived from the West Mariana Ridge. The initial rifting during the onset of spreading of the Mariana Trough may have produced the deep graben-shaped depression at Site 453, and provided the vertical displacement needed to get the arc-derived rocks into their present location.

\section{HEAT FLOW}

At Site 453 , a terrestrial heat flow experiment was conducted for the first time using the new Tokyo Tprobe developed by Yokota et al. (1980). The downhole temperature measured at a sub-bottom depth of 75.5 meters was $11.9^{\circ} \mathrm{C}$. This value and the bottom water temperature $\left(1.7-2.2^{\circ} \mathrm{C}\right)$ gave the geothermal gradient value of $12.8-13.5^{\circ} \mathrm{C} / 100$ meters. The in situ thermal conductivity of the sediments was estimated as 1.82 


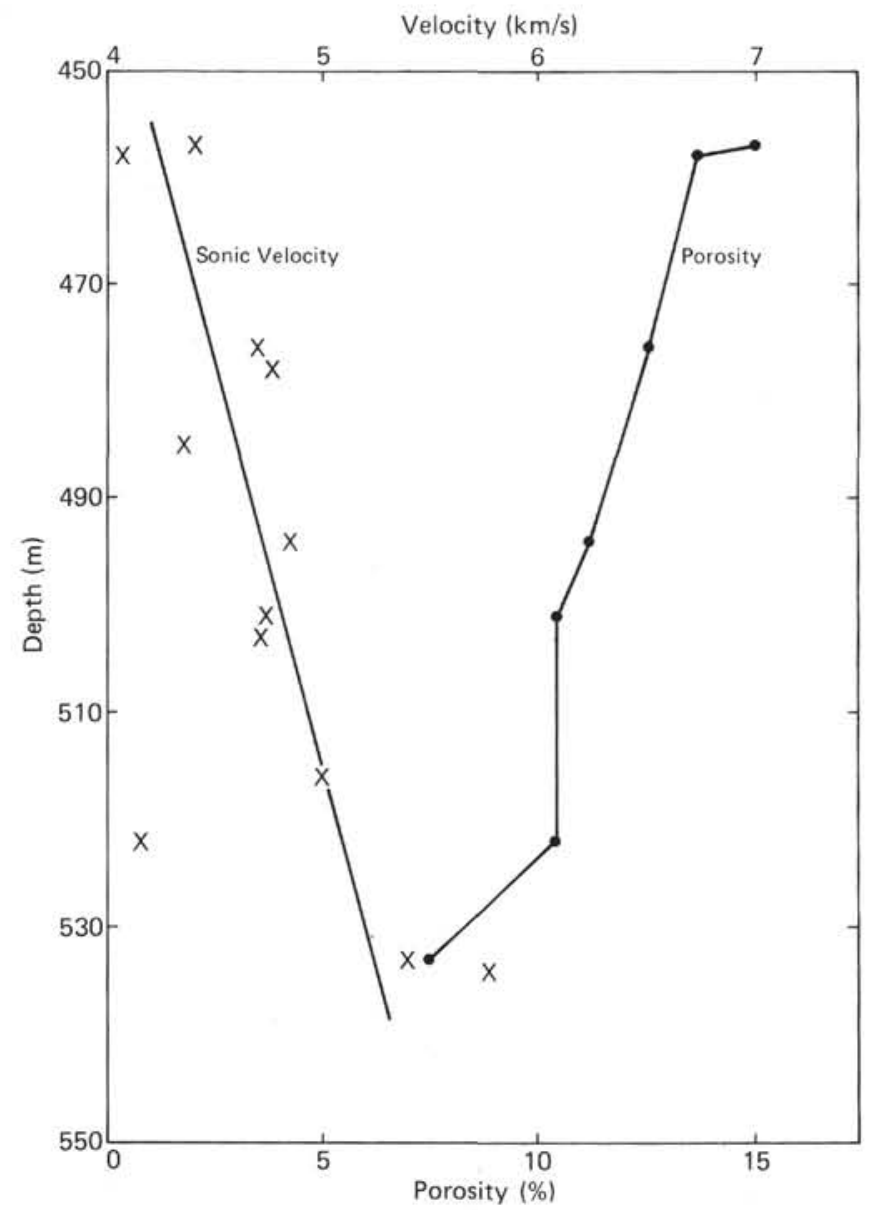

Figure 14. Variation of sonic velocity and porosity of polymict breccia and meta-igneous rock samples versus depth below sea floor from which the cores came in Hole 453. Using the values, an average seismic compressional velocity of $4.75 \mathrm{~km} / \mathrm{s}$ was assumed for these rocks.

$\mathrm{mcal} / \mathrm{cm} \mathrm{s}{ }^{\circ} \mathrm{C}$, from measurements on 28 samples recovered (Horai, this volume) between the sea bottom and a depth of 88.3 meters. On the basis of these values of the geothermal gradient and thermal conductivity, the heat flow for the depth interval 0-75.5 meters was estimated at $2.33-2.46 \times 10^{-6} \mathrm{cal} / \mathrm{cm}^{2} \mathrm{~s}$ (HFU), the mean being $2.40 \mathrm{HFU}$.

The heat flow value of $2.40 \mathrm{HFU}$ obtained here, though estimated from only a single temperature measurement, may be considered reliable. This value is significantly higher than the average oceanic heat flow but is reasonable for young sea floor such as the Mariana Trough (Watanabe et al., 1977). Heat flow measurements taken previously in this area by a conventional oceanic heat flow probe are below 1 HFU (Anderson, 1975). In view of the possibility that the heat transfer in the young crust is largely controlled by hydrothermal circulation, local high variability is expected. An additional series of conventional heat flow stations obtained after Leg 60 did find this expected high variability (Hobart et al., 1979). The igneous rocks sampled from the bottom of Site 453 exhibited both petrologic and paleomagnetic evidence of hydrothermal alteration (see section on petrology and paleomagnetism, this chapter).

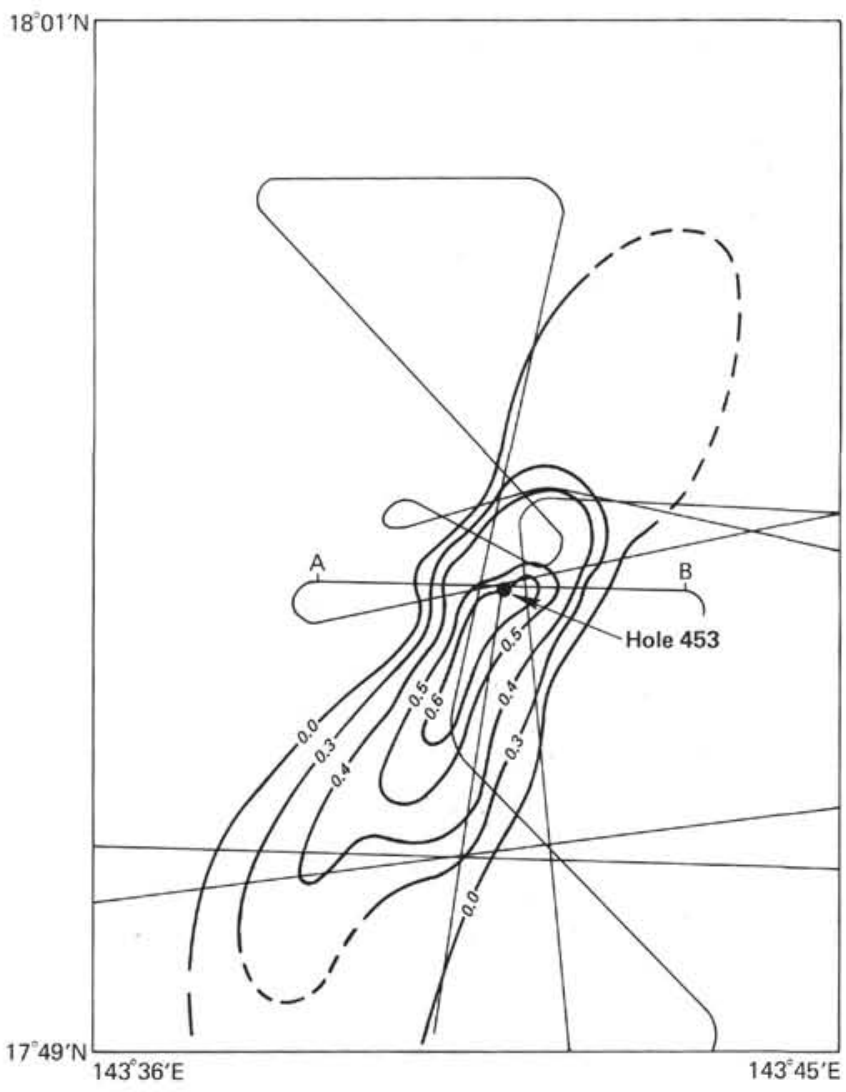

Figure 15. Sediment isopach in seconds of two-way travel time near Site 453. The reflection profile shown as Figure 13 is located along the A-B track line segment. Data from tracks of the Glomar Challenger, Kana Keoki, and Conrad.

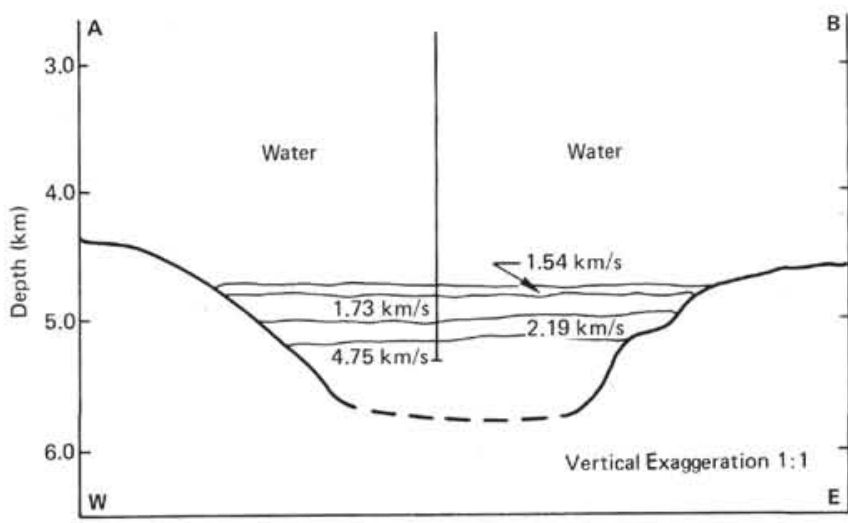

Figure 16. Depth section of the sediment pond at Site 453 showing the position of the drill string at the deepest core. The seismic velocities in each of the layers is averaged from shipboard measurements of core samples.

Details of the heat flow measurements are given in Uyeda and Horai (this volume).

\section{SUMMARY AND CONCLUSIONS}

Any evaluation of the results of the Site 453 drilling in relation to the objectives set forth in the beginning of this chapter must be tempered by the recognition that we can conclude little about the origin of the crust beneath this site. Although we penetrated nearly 150 


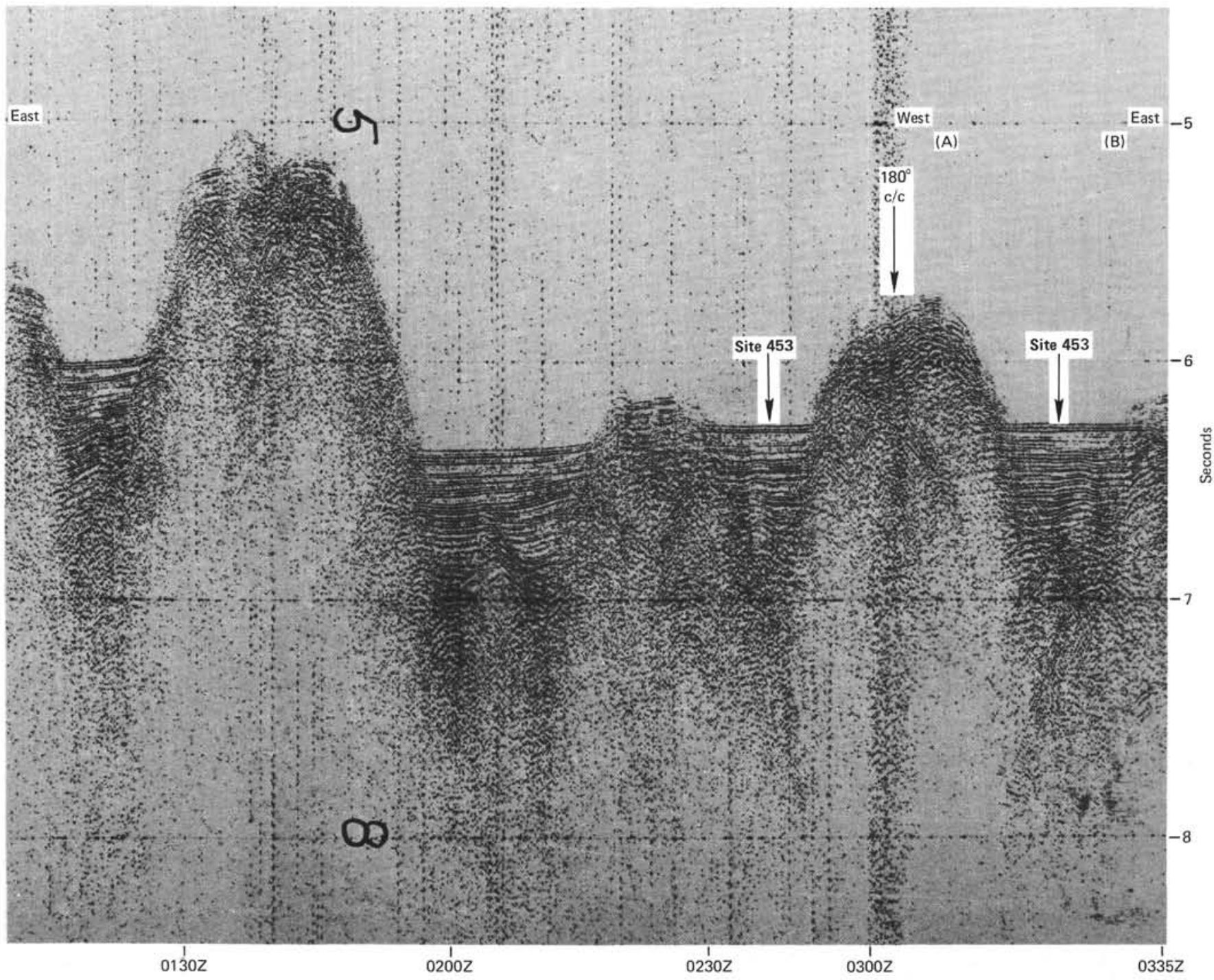

Figure 17. Two crossings of Site 453 and the two sediment ponds east of the drill site. Note that the ponds are at very different depths, demonstrating that there is no sediment transport path between adjacent ponds because of intervening bathymetric relief. Nevertheless, the acoustic character of the reflectors (depth below sea floor and relative amplitude) is highly similar in the ponds, suggesting they both underwent a similar sedimentation history.

meters of igneous and meta-igneous rocks beneath the 455.5 meters of sediment in Hole 453, an evaluation of the seismic reflection profiles over the site indicates that acoustic basement, though poorly defined, is much deeper. Correlation of seismic reflectors with depth, at which major changes of acoustic impedance were calculated from shipboard measurement of the physical properties of the cores, was good in the sediment. Although the top of the breccias produced a less distinct reflection than would be expected (at $\sim 0.5$-s reflection time), strong reflectors are observed to sub-bottom depth of over $0.7 \mathrm{~s}$. This indicates that we were still more than 300 meters from acoustic basement when the drill bit apparently failed.

The rocks that were recovered are all derived from an island arc, and we assume that they are tectonically displaced from the West Mariana arc during initial rifting of the Mariana Trough. This would suggest that the crust beneath Site 453 may not be part of the Trough.
However, the rocks have been exposed to a high degree of hydrothermal metamorphism that produces alteration similar to that encountered on other Mariana Trough sites (e.g., Site 454). Extremely high and variable heat flow $(\sim 0->20$ HFU; Hobart et al., 1979) was also measured in the Site 453 sediment pond. These indications of pronounced hydrothermal circulation suggest that the crust beneath Site 453, perhaps at the depth of the acoustic basement, may be part of the Mariana Trough.

Regardless of the nature of the underlying crust at Site 453 , we also are at a loss to explain how the large volume of apparently flat-lying breccias were emplaced in the pond. The surrounding ridges seem to be distant and small sources for the voluminous breccias. The breccias are also of two distinct types $(86 \mathrm{~m}$ of gabbroic breccia with large clasts overlying $29 \mathrm{~m}$ of very different volcanic breccia with much smaller clasts), suggesting that two different events and/or sources produced the 
breccias at the time of initial back-arc basin formation, after which sedimentation began about 5 m.y. ago. None of the explanations for the breccias suggested in this chapter (talus pile, avalanche deposits, drilling in a fault plane) adequately explains their character.

The sediments at Site 453 are of predominant islandarc volcanic origin. By the early Pliocene, volcanism had ceased on the West Mariana Ridge (Site 451; Kroenke, Scott et al., 1980) suggesting that the present Mariana arc volcanoes were the source of the sediments. At first the sedimentation rate was very high $\left(\sim 34 \mathrm{~kg} / \mathrm{cm}^{2}\right)$ m.y.) at Site 453 , but this rate uniformly decreased with time as the trough opened and the arc volcanoes moved away to the east. The progressive filling of the bathymetric lows in the western Mariana Trough would reduce the ratio of the area of the turbidite source to the area of deposition, thereby effectively slowing the sedimentation rate. However, this effect, because of the rugged terrain near Site 453, is minor compared to the dramatic rate of slowing of deposition observed at the site. Only a slight increase in the sedimentation rate in the late Pliocene-early Pleistocene (1.8-0.9 m.y. ago) deviates from this uniform decrease in sedimentation, and may therefore represent an episode of increased volcanism.

On the basis of the paleontologic and paleomagnetic age determination of the basal sediments at Site 453, the half-rate of spreading of the Mariana Trough must be less than $2.4 \mathrm{~cm} / \mathrm{y}$. The apparent uniform decrease in sedimentation rate suggests that this spreading (and then the removal of the volcanic source from Site 453) must have been similarly uniform.

\section{REFERENCES}

Anderson, R. N., 1975. Heat flow in the Mariana Marginal Basin. J. Geophys. Res., 80:4043-4048.

Bukry, D., 1975. Coccolith and silicoflagellate stratigraphy, northwestern Pacific Ocean, Deep Sea Drilling Project Leg 32. In Larson, R. L., Moberly, R., et al., Init. Repts. DSDP, 32: Washington (U.S. Govt. Printing Office), 677-701.

Deer, W. A., Howie, R. A., and Zussman, J., 1966. An Introduction to the Rock-forming Minerals: New York (John Wiley and Sons).

Ellis, C. H., and Lohman, W. H., 1979. Neogene calcareous nannoplankton biostratigraphy in eastern Mediterranean deep-sea sediments (DSDP Leg 42A, Sites 375 and 376). Mar. Micropaleont., 4:61-84.

Hobart, M. A., Anderson, R. N., and Uyeda, S., 1979. Heat transfer in the Mariana trough. EOS, 60:383.

Kroenke, L., Scott, R., et al., 1980. Init. Repts. DSDP, 59: Washington (U.S. Govt. Printing Office).

Nigrini, C. A., 1971. Radiolarian zones in the Quaternary of the equatorial Pacific. In Funnel, B. M., and Riedel, W. R. (Eds.), The Micropaleontology of Oceans: London (Cambridge University Press), pp. 443-461.

Watanabe, T., Langseth, M. G., and Anderson, R. N., 1977. Heat flow in back-arc basins of the Western Pacific. In Talwani, M., and Pitmann III, W. C. (Eds.), Island Arcs, Deep Sea Trenches and Back-Arc Basins: Maurice Ewing Series I: Washington (Am. Geophys. Union), pp. 137-161.

Yokota, T., Kinoshita, H., and Uyeda, S., 1980. New DSDP (Deep Sea Drilling Project) downhole temperature probe utilizing digital self-recording system with IC RAM elements. Bull Earthq. Res. Inst. 55:75-88. 

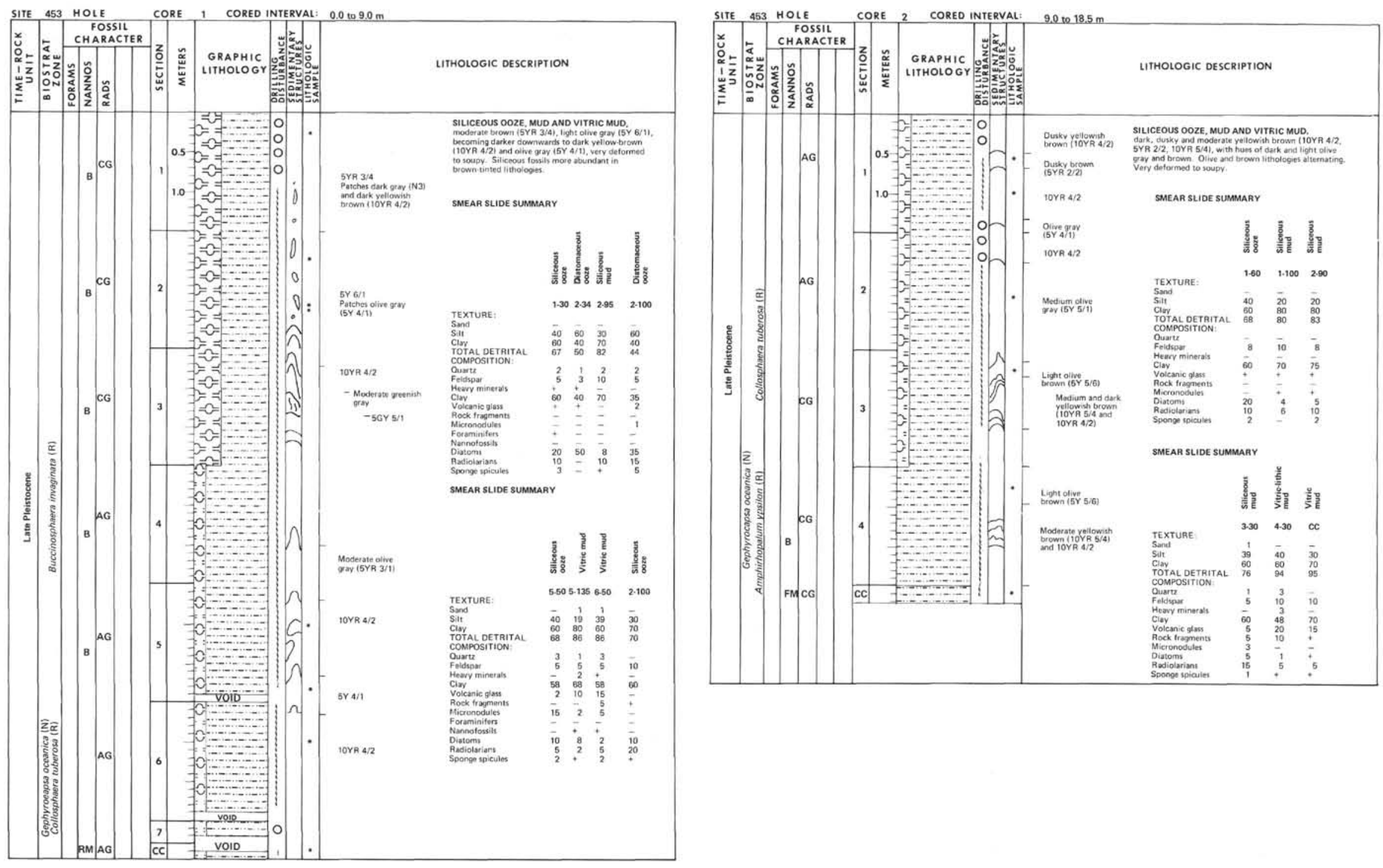


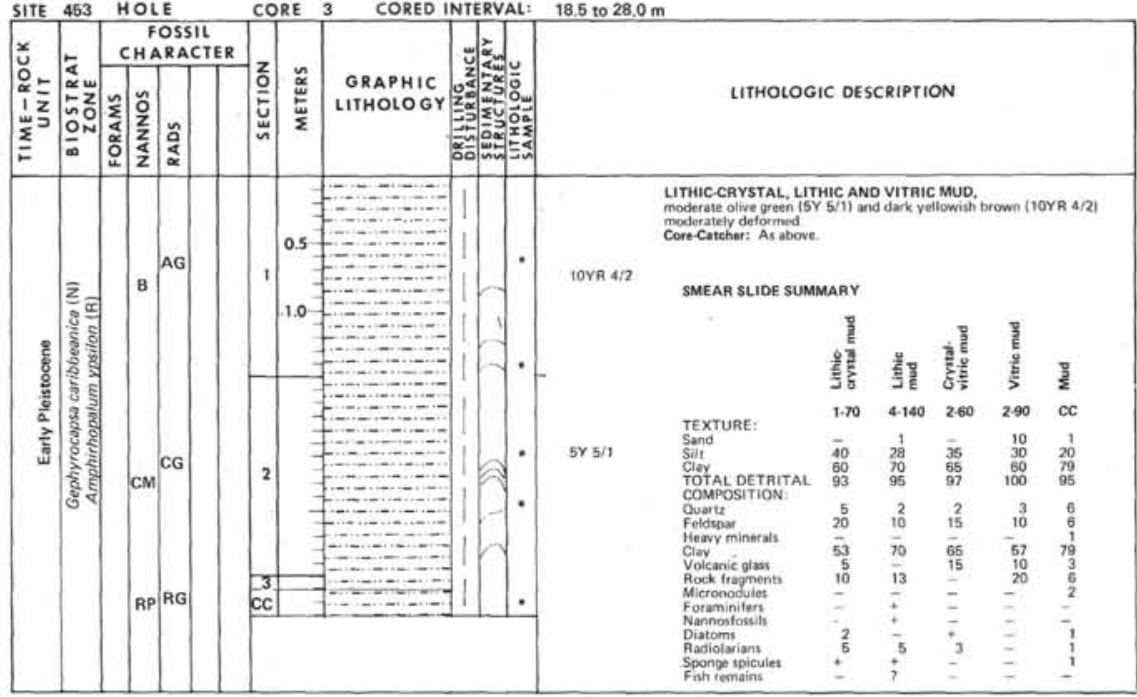

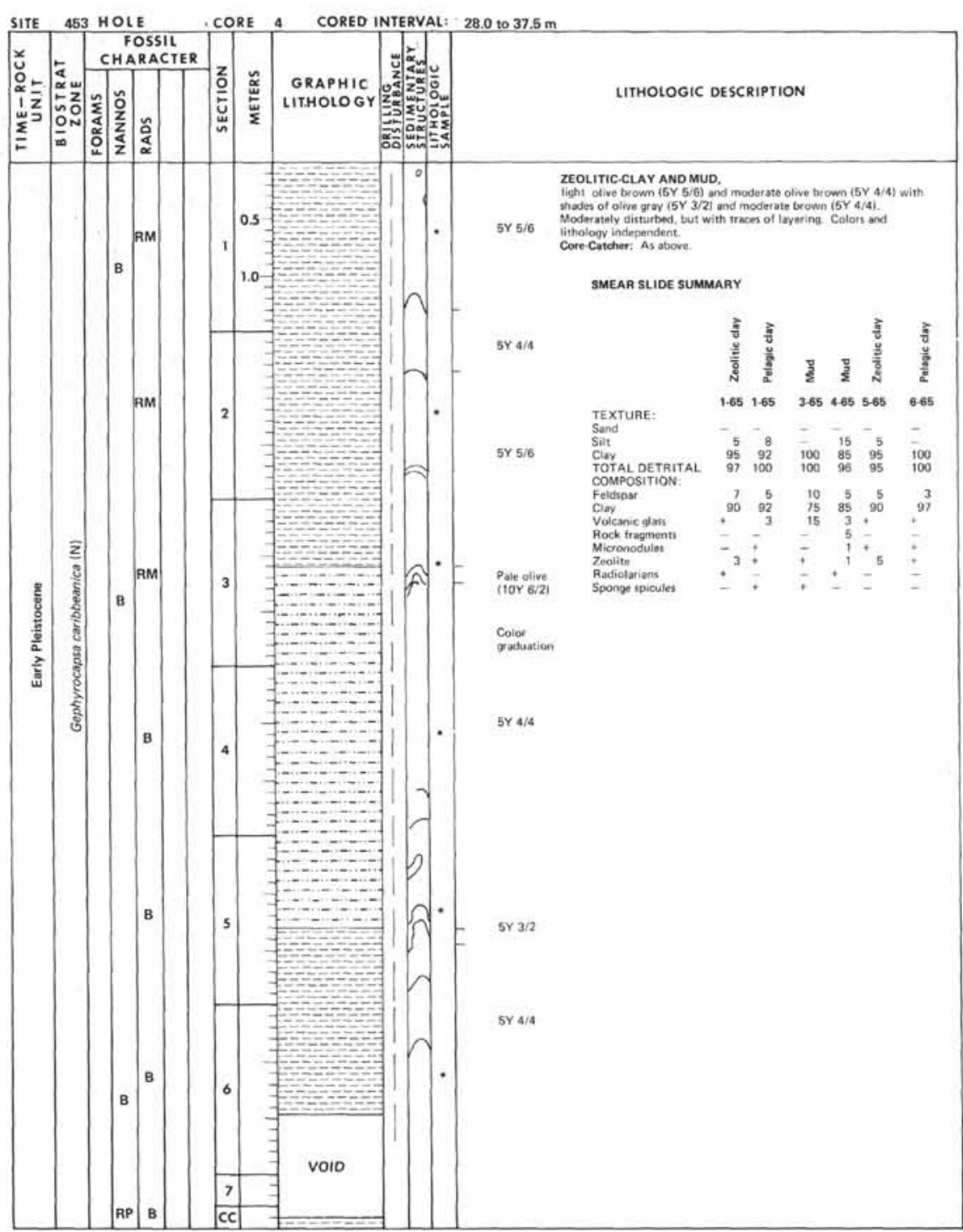




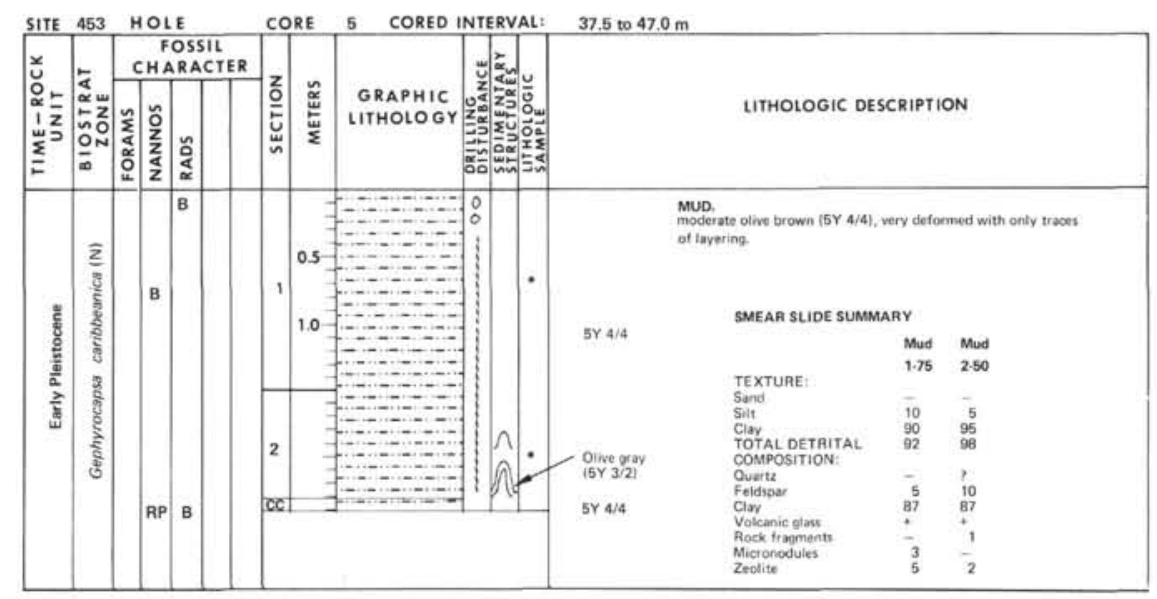

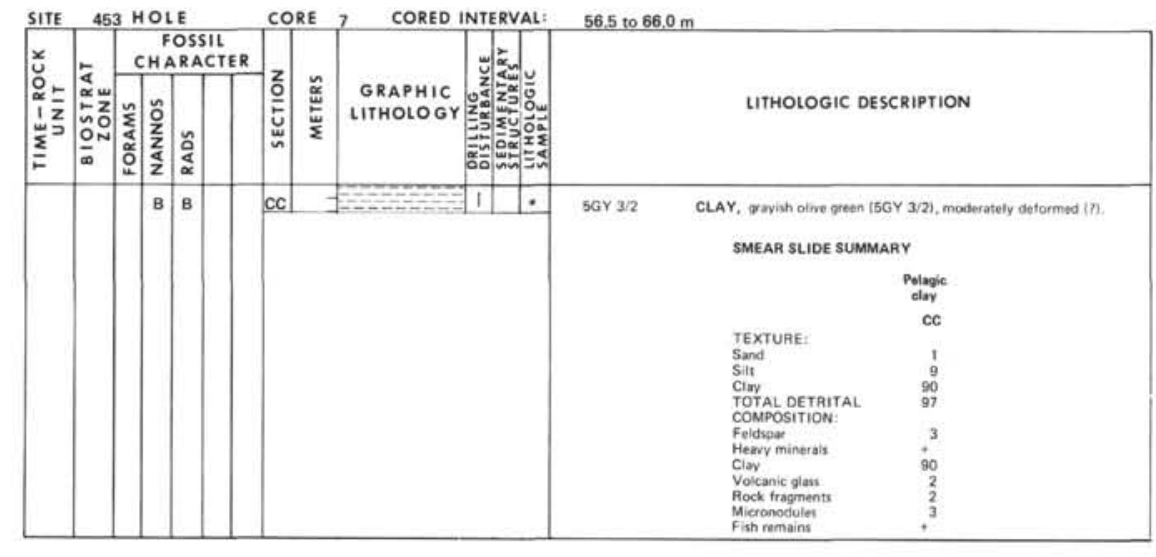

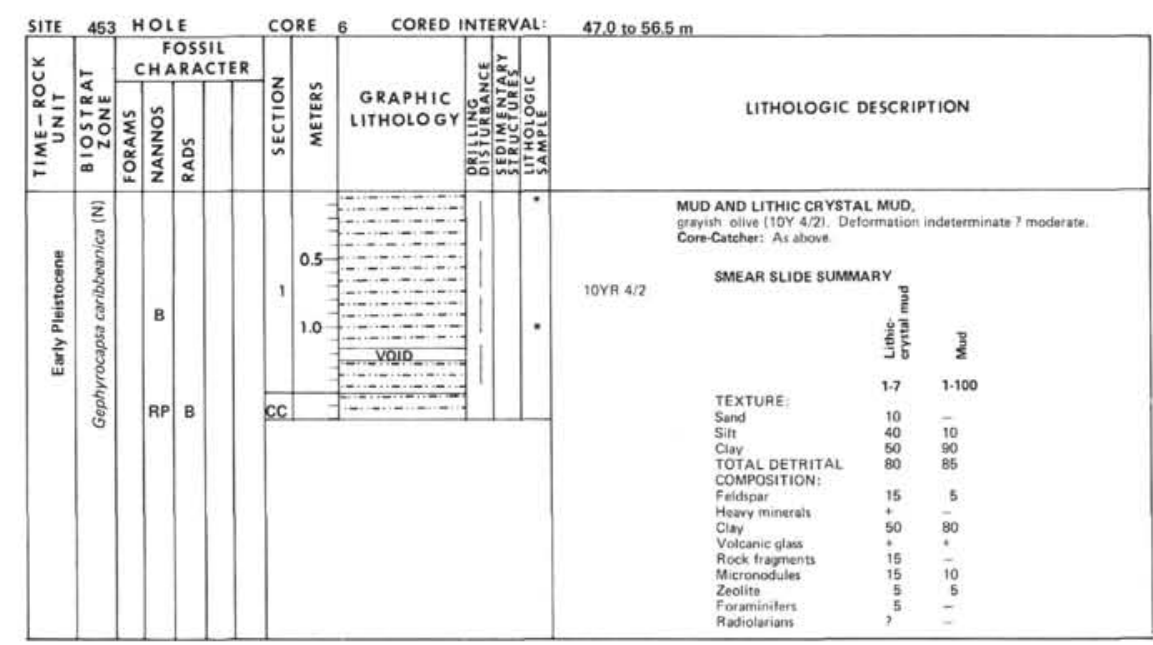




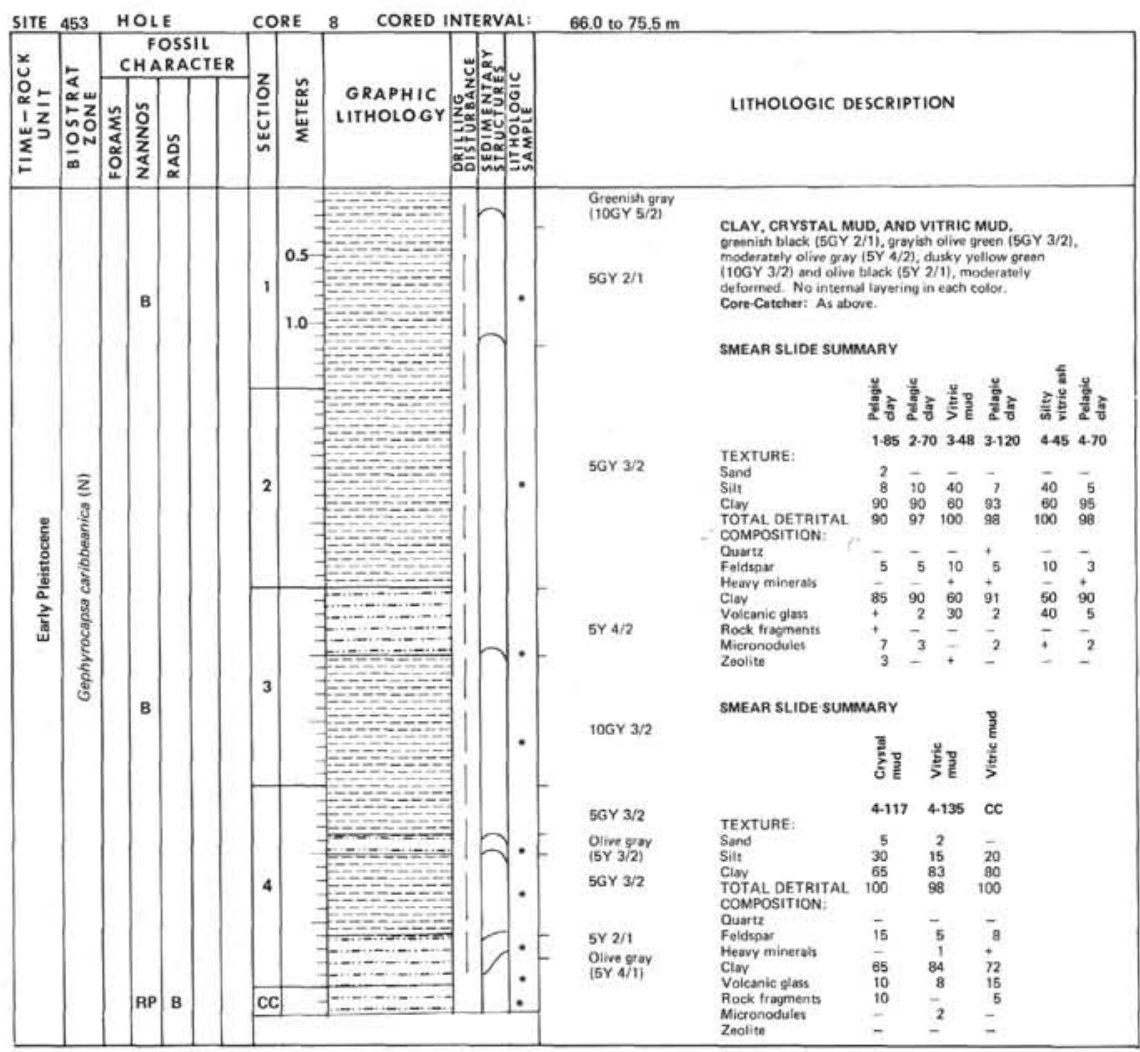

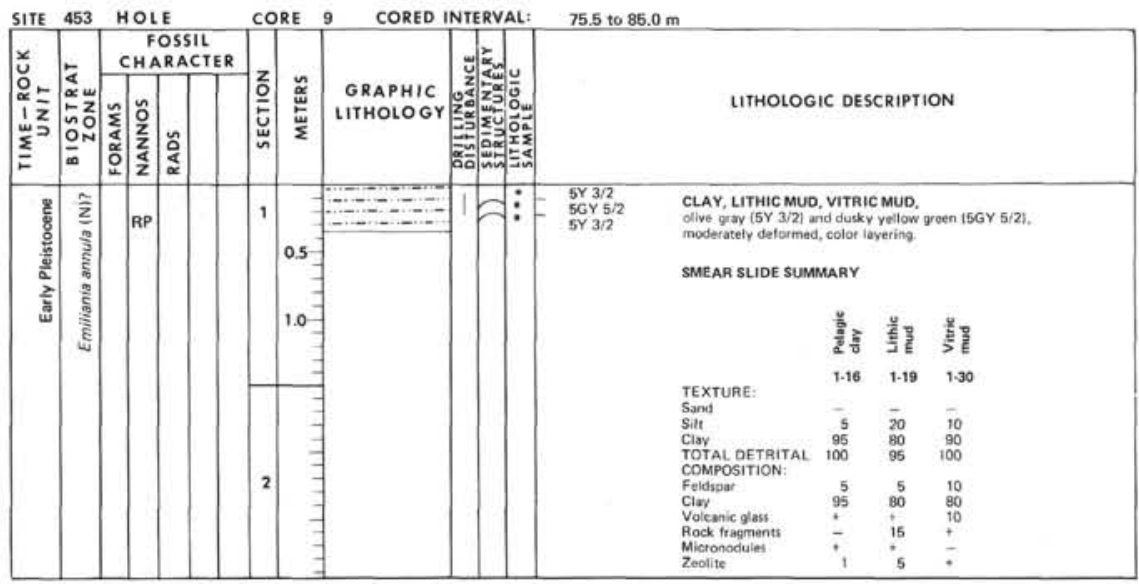

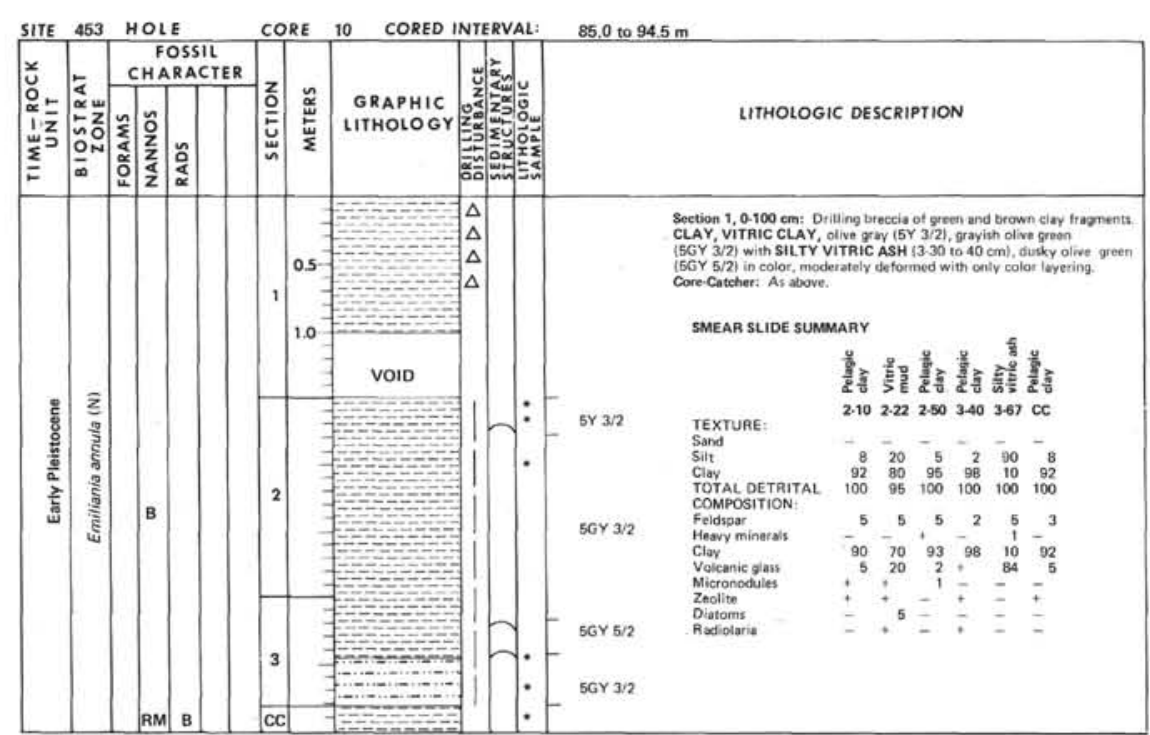



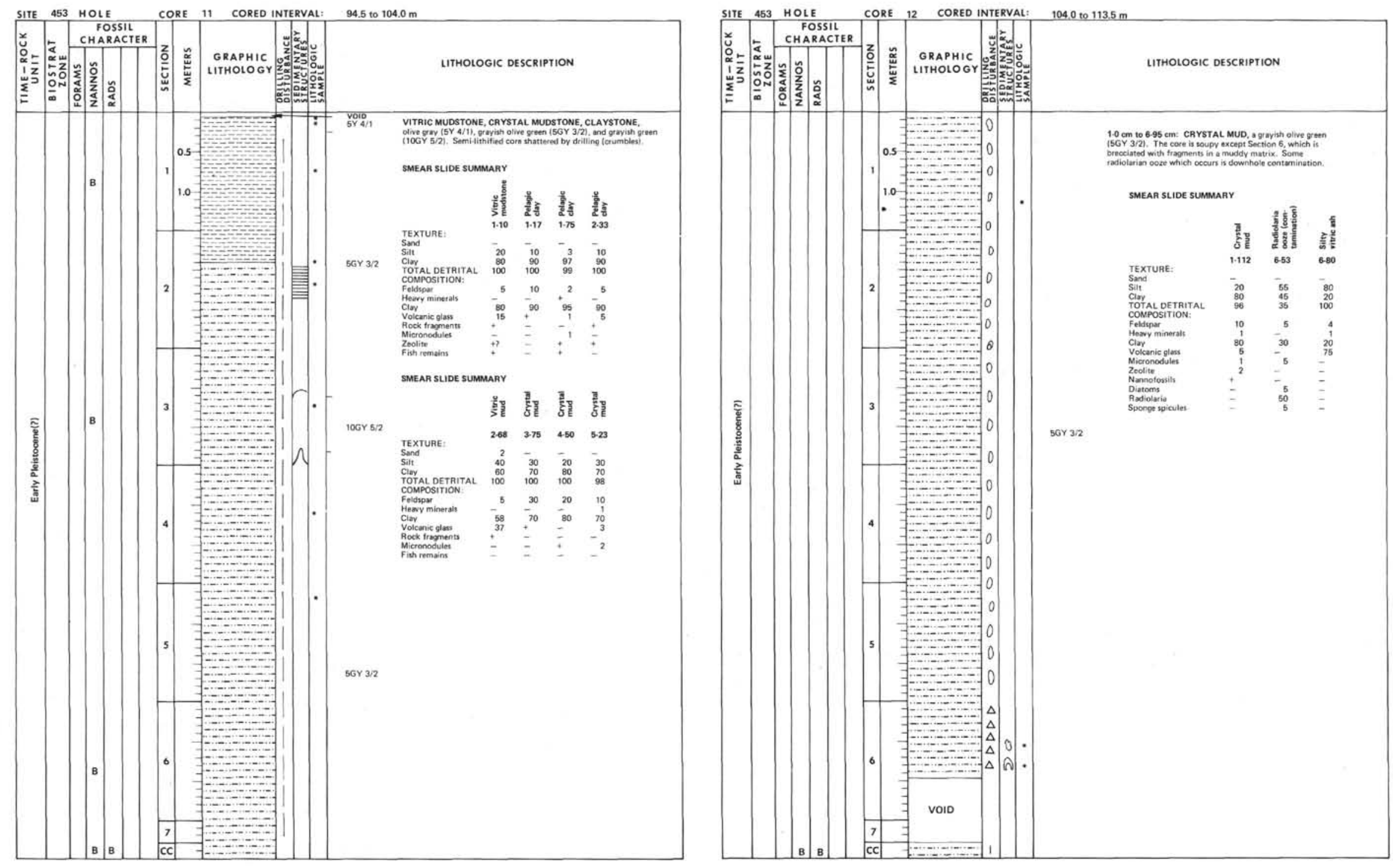

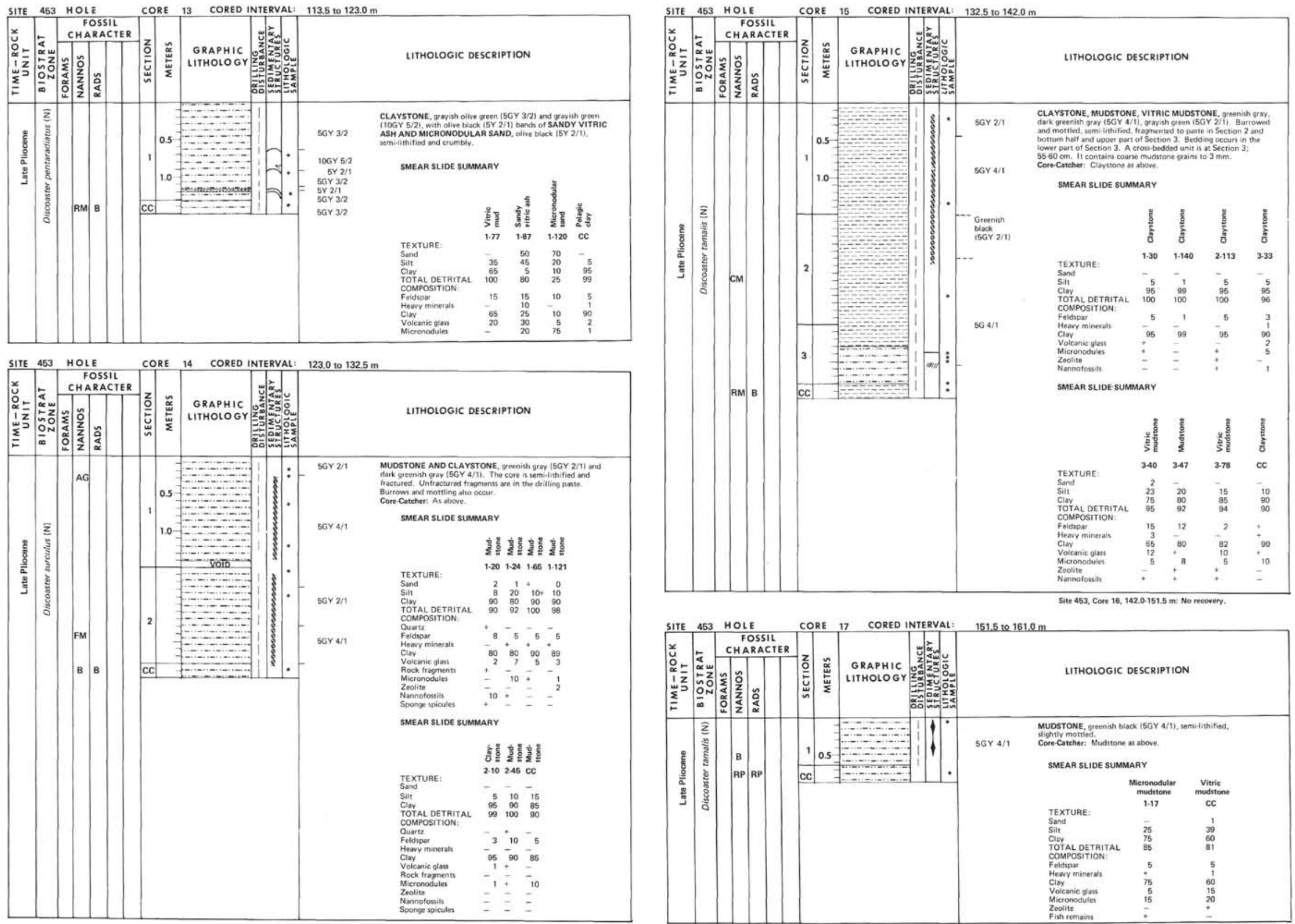

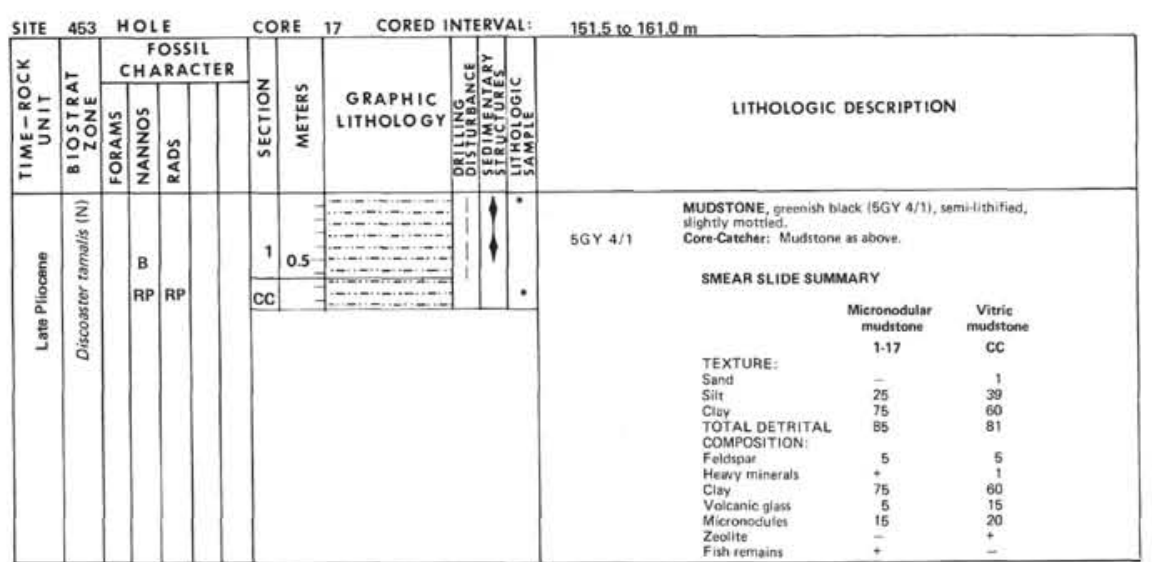




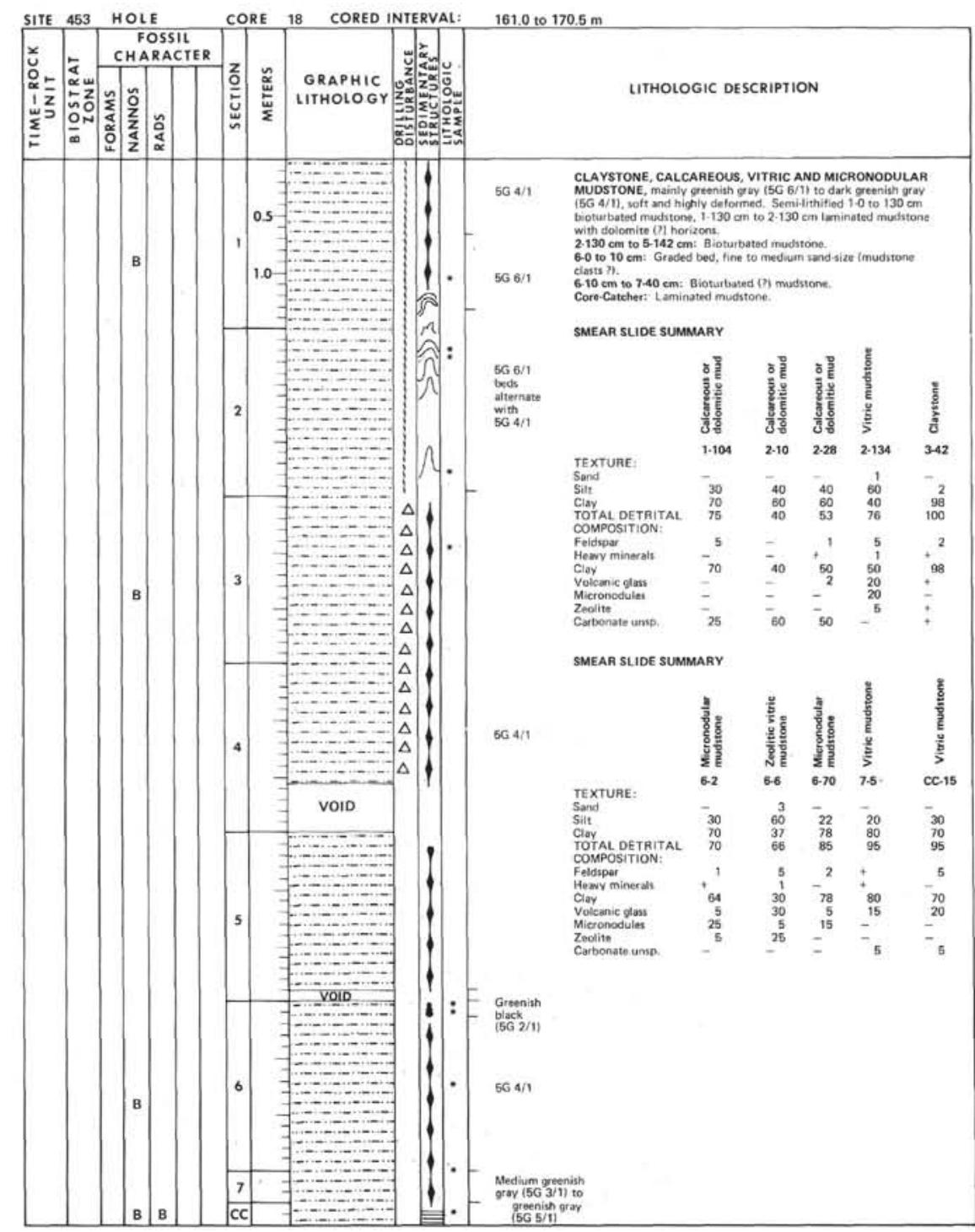

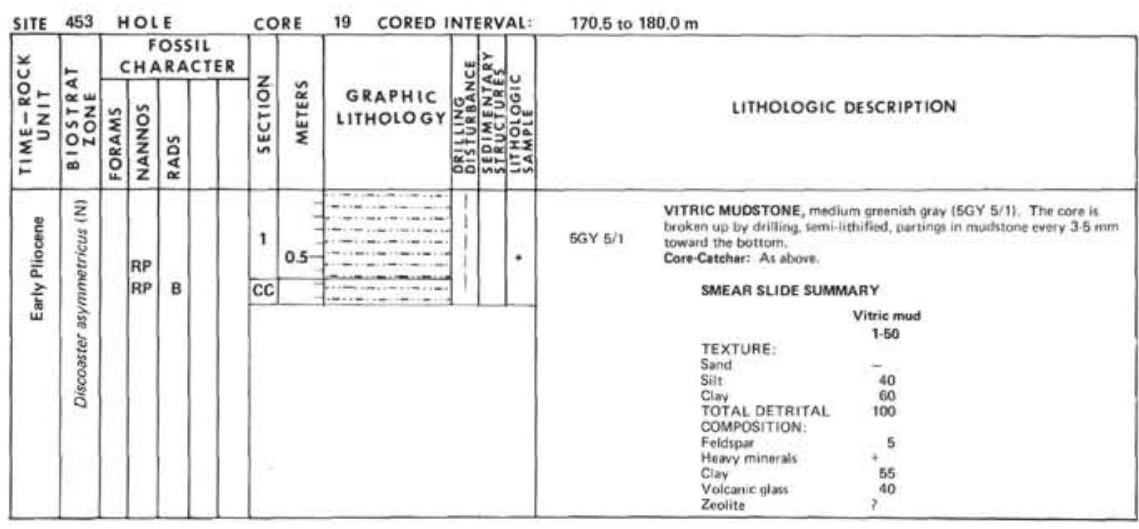

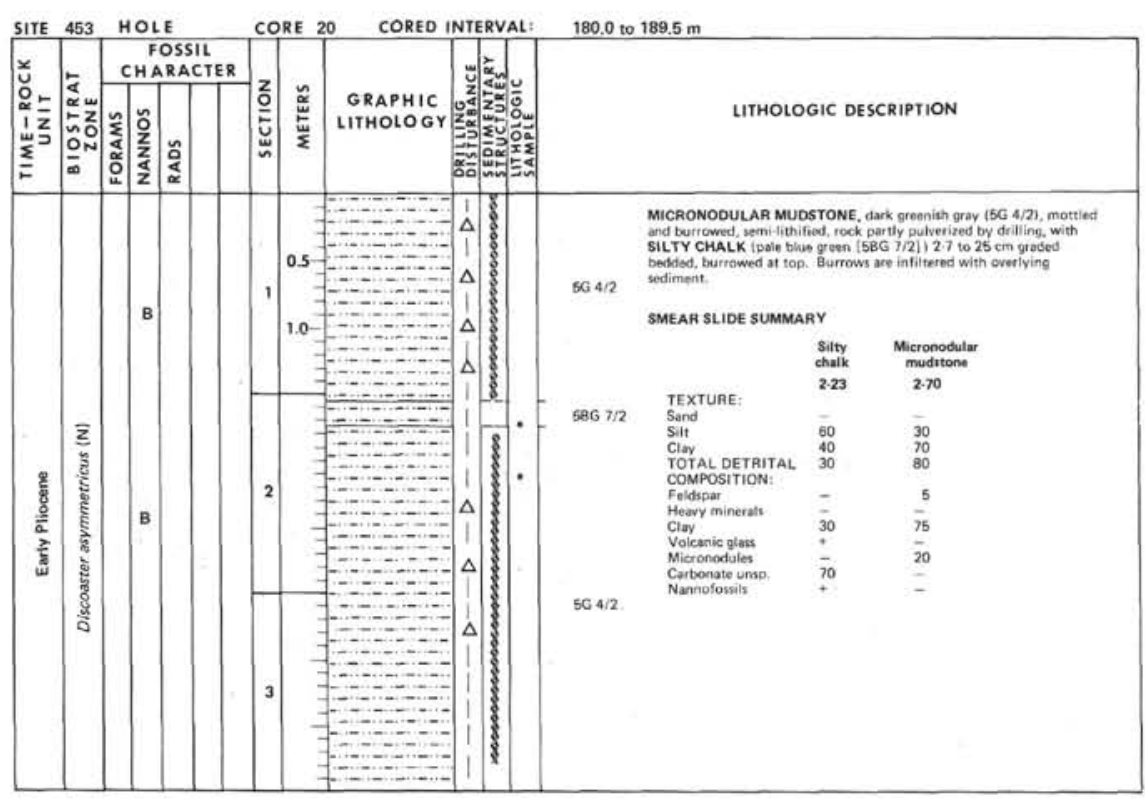



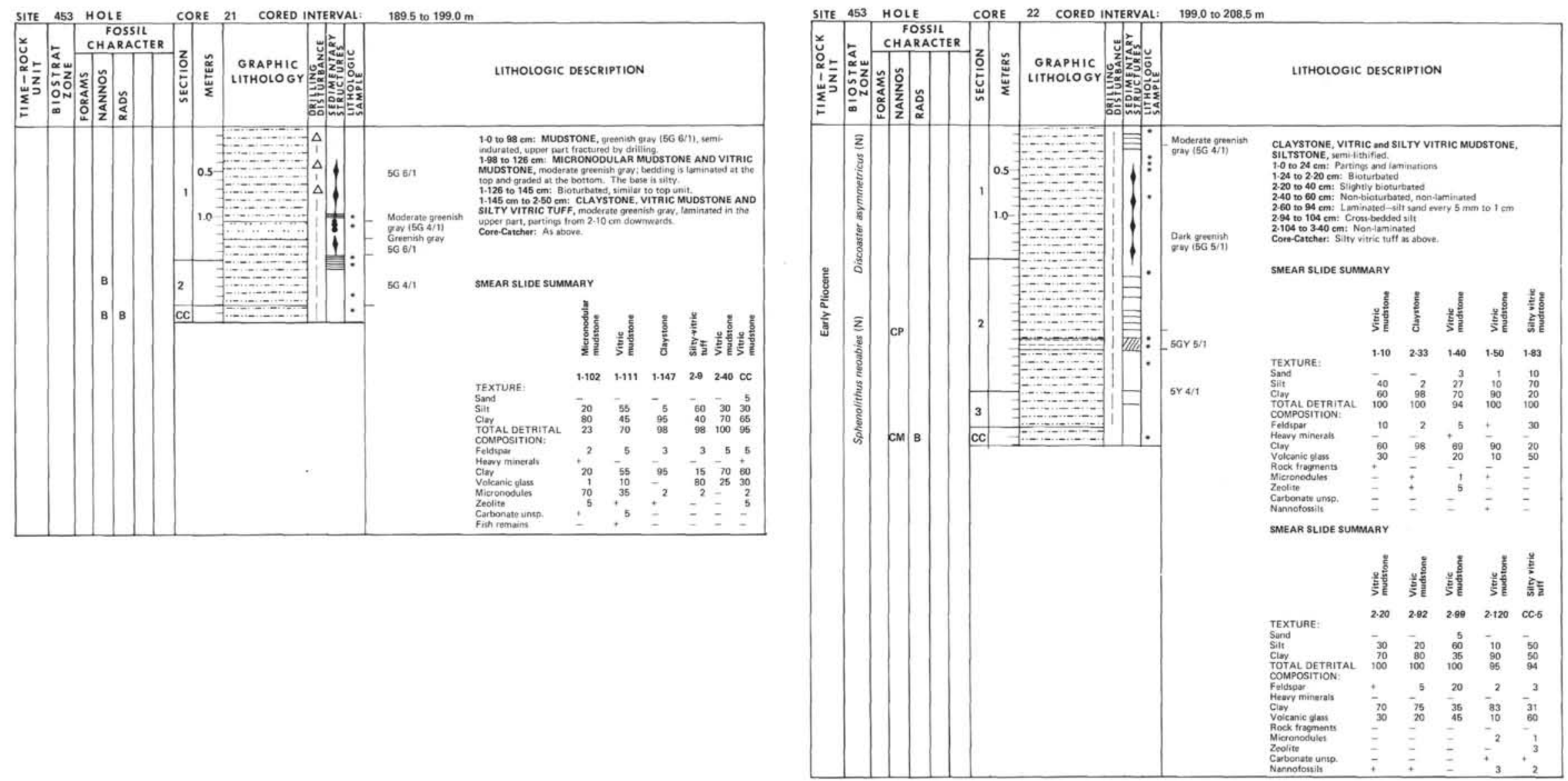


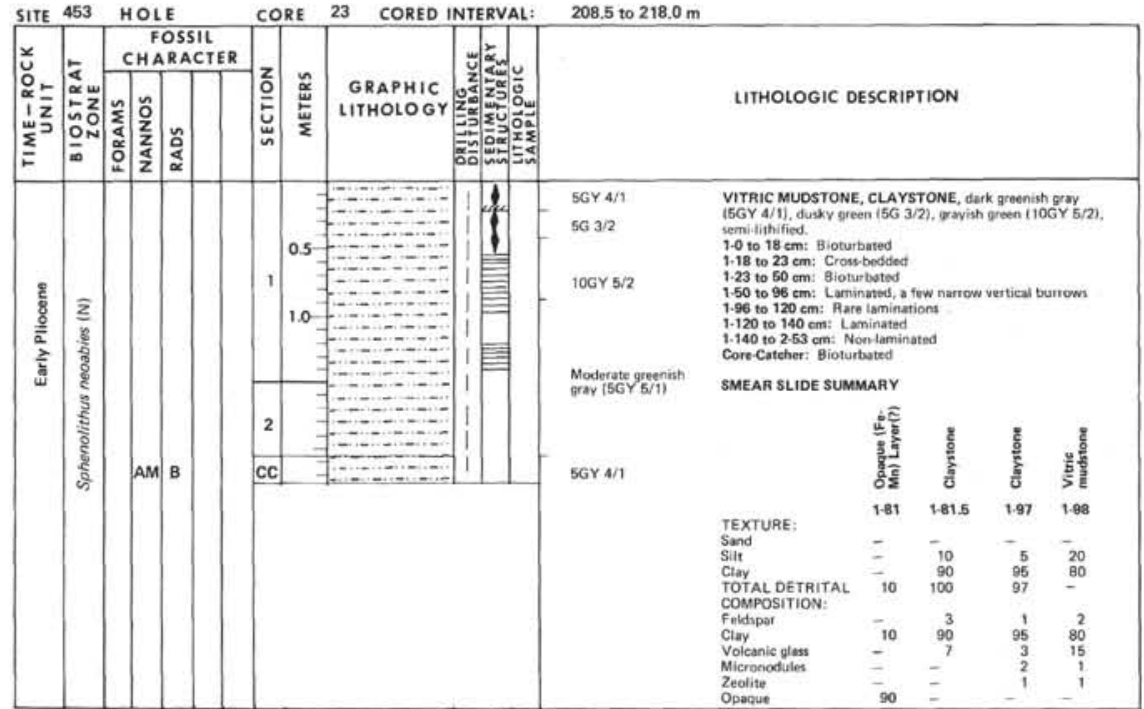

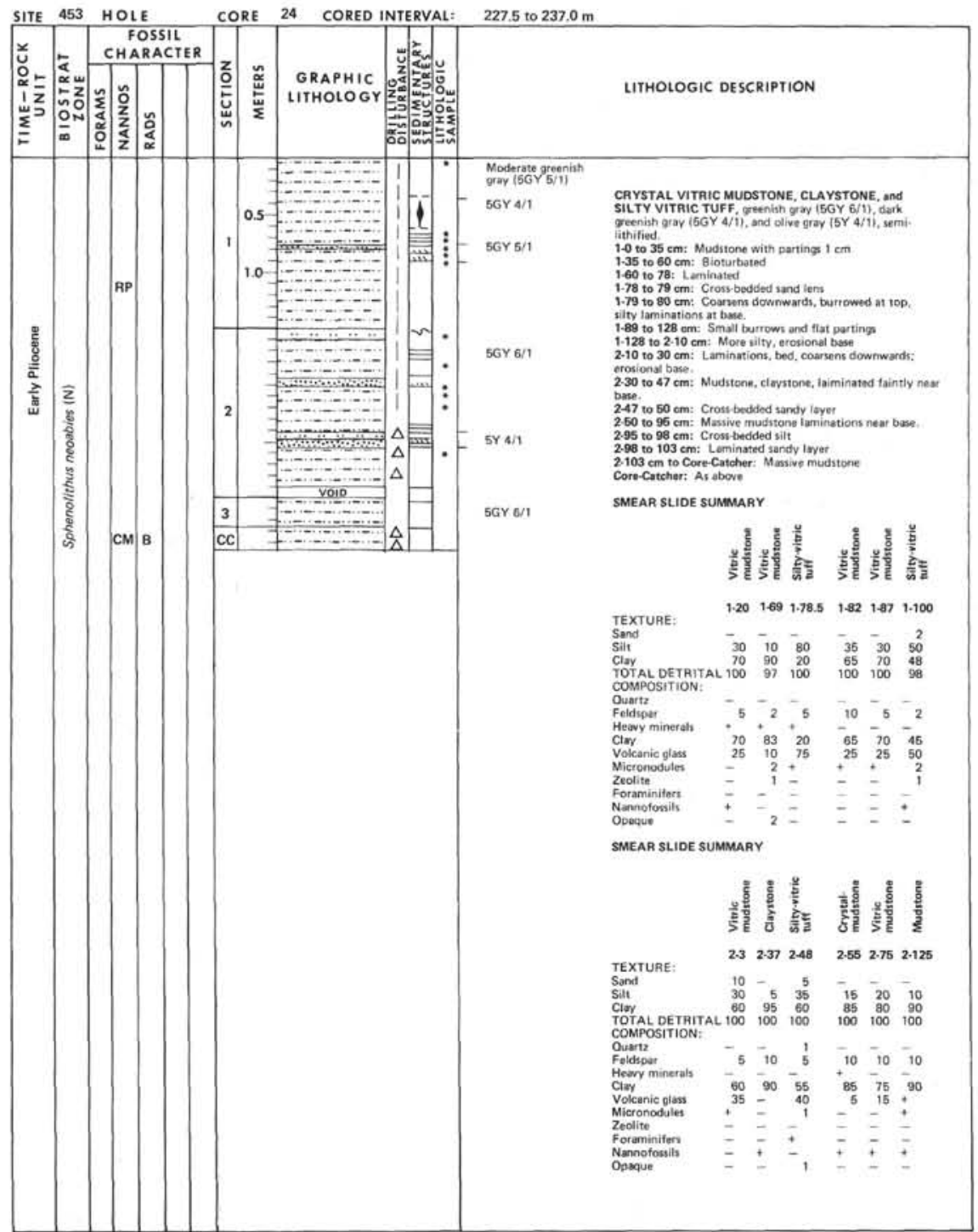



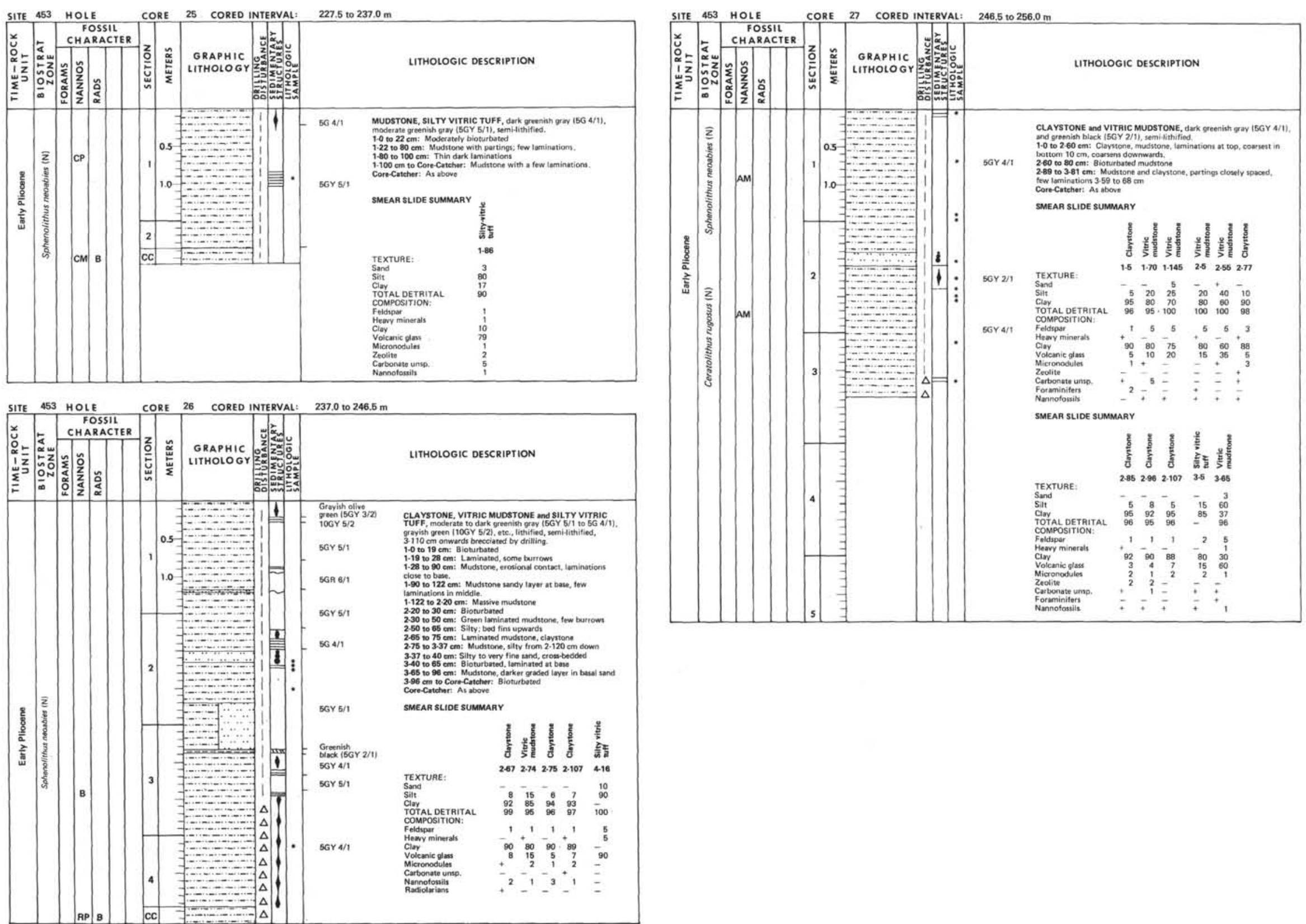

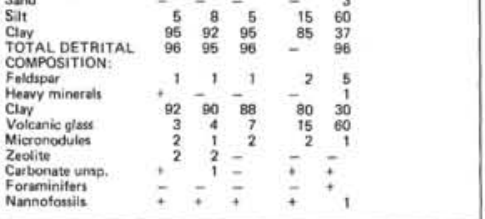




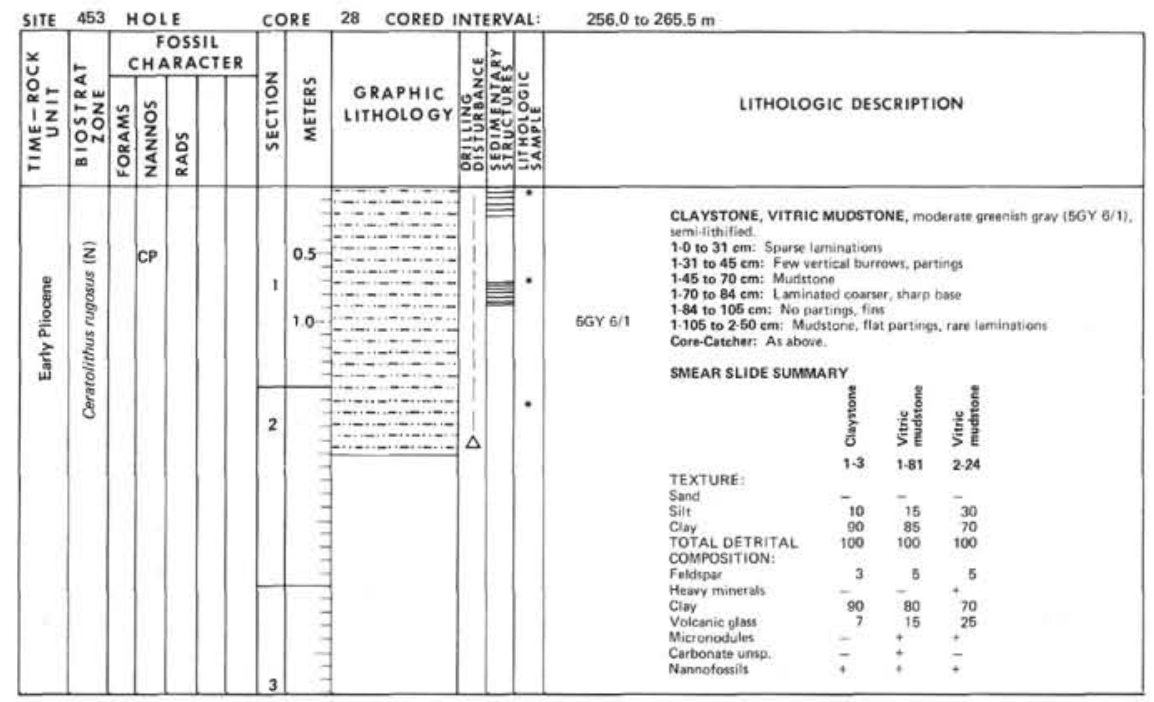

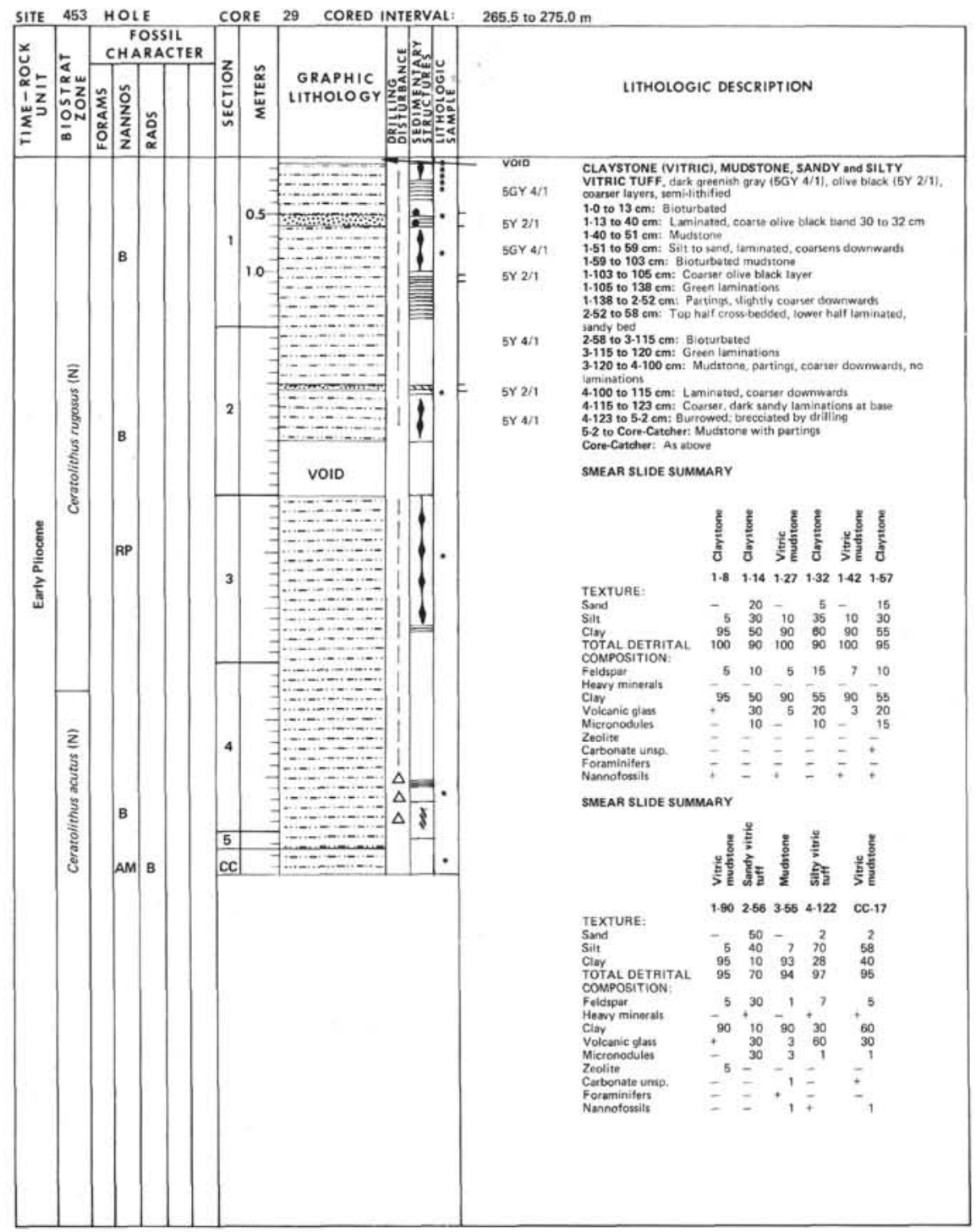



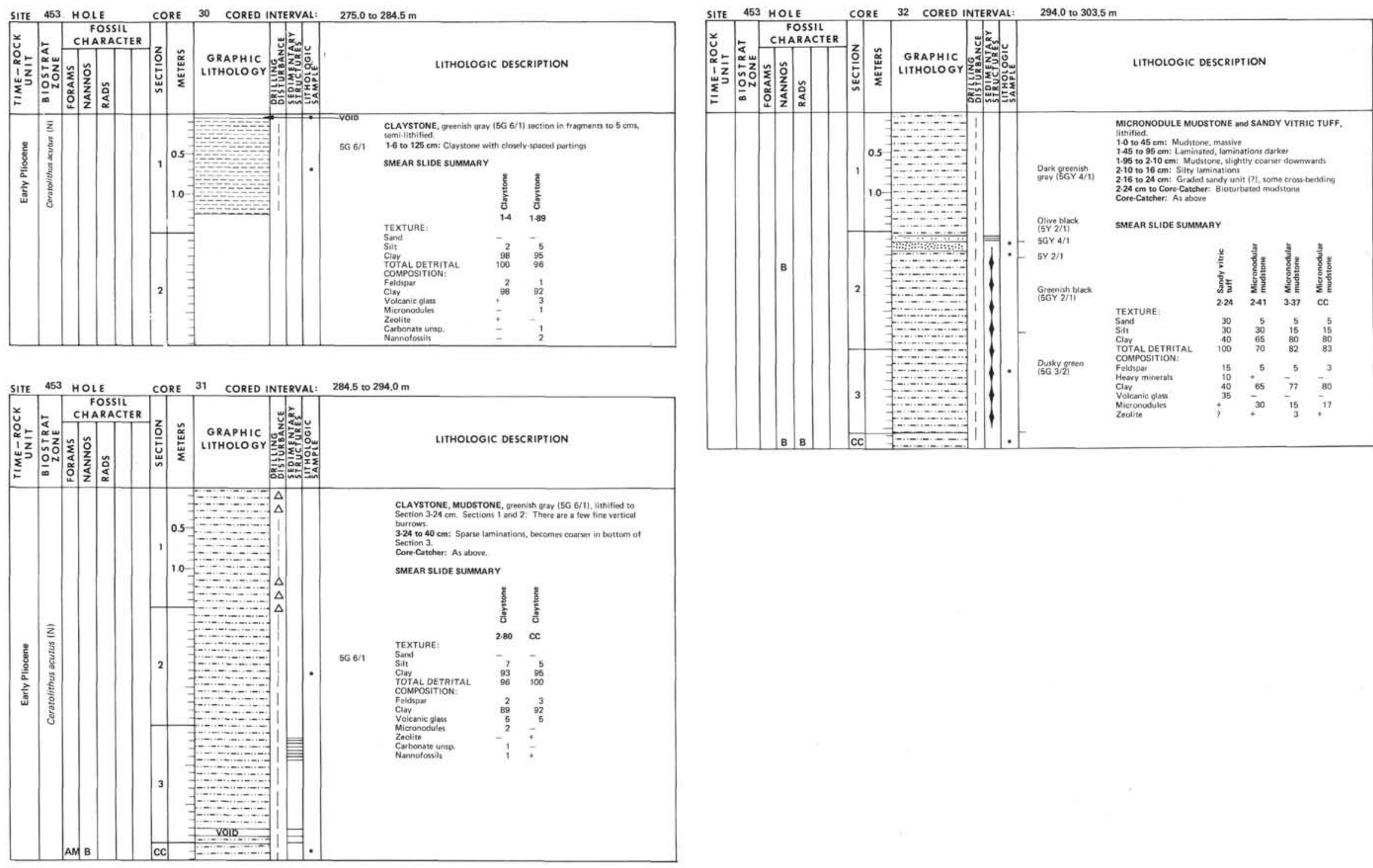


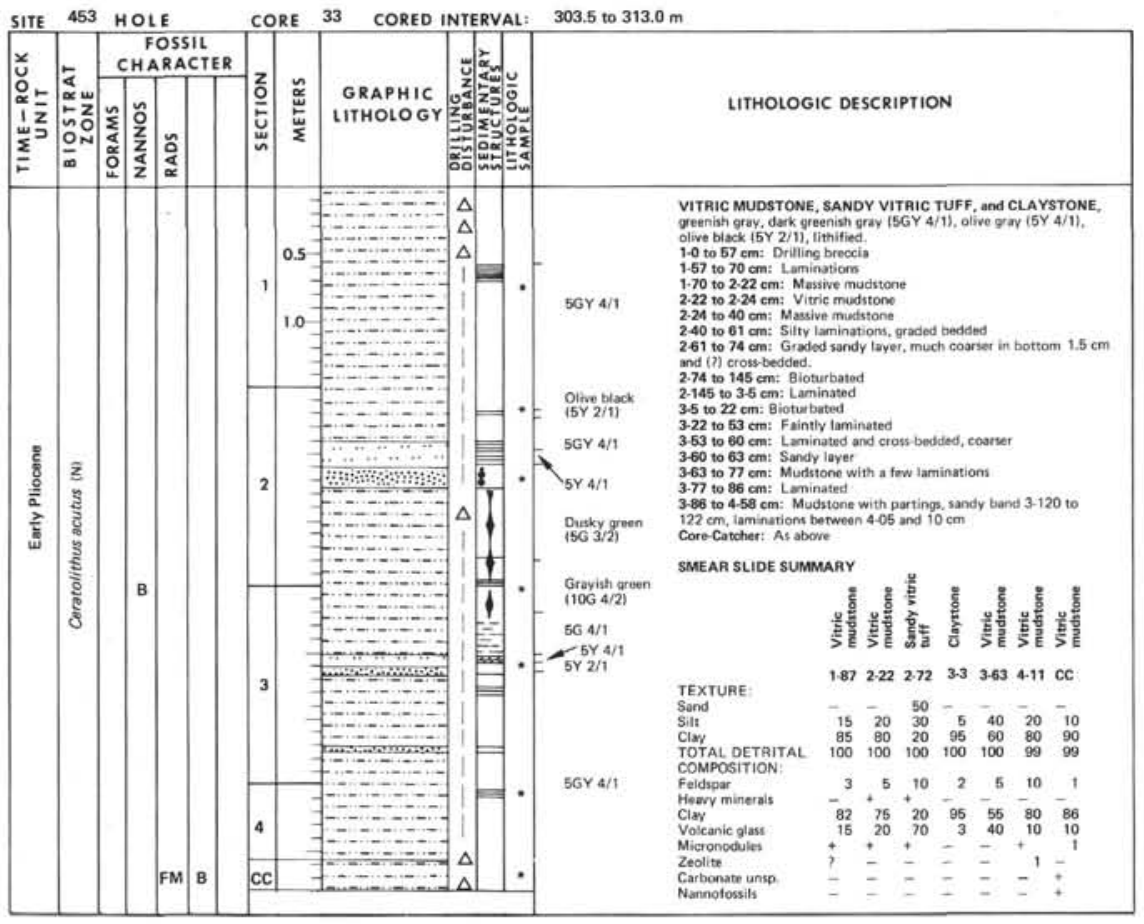

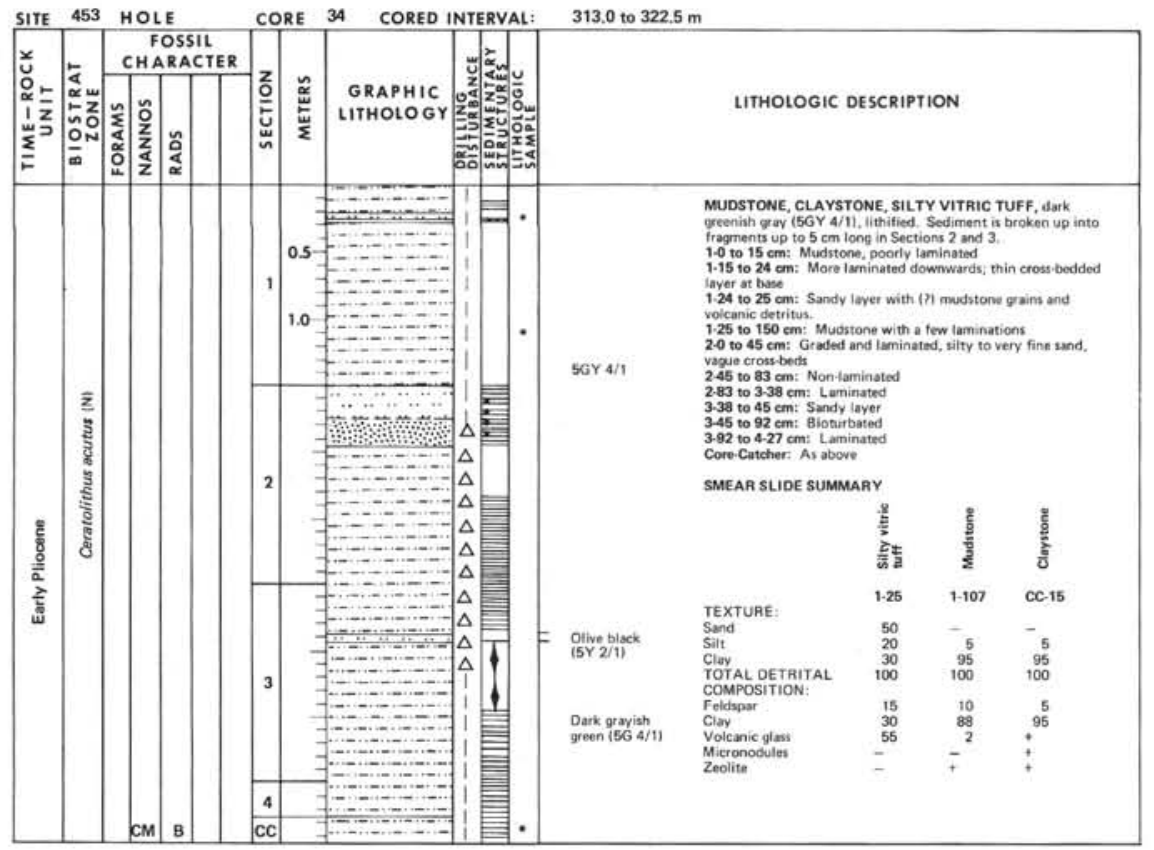




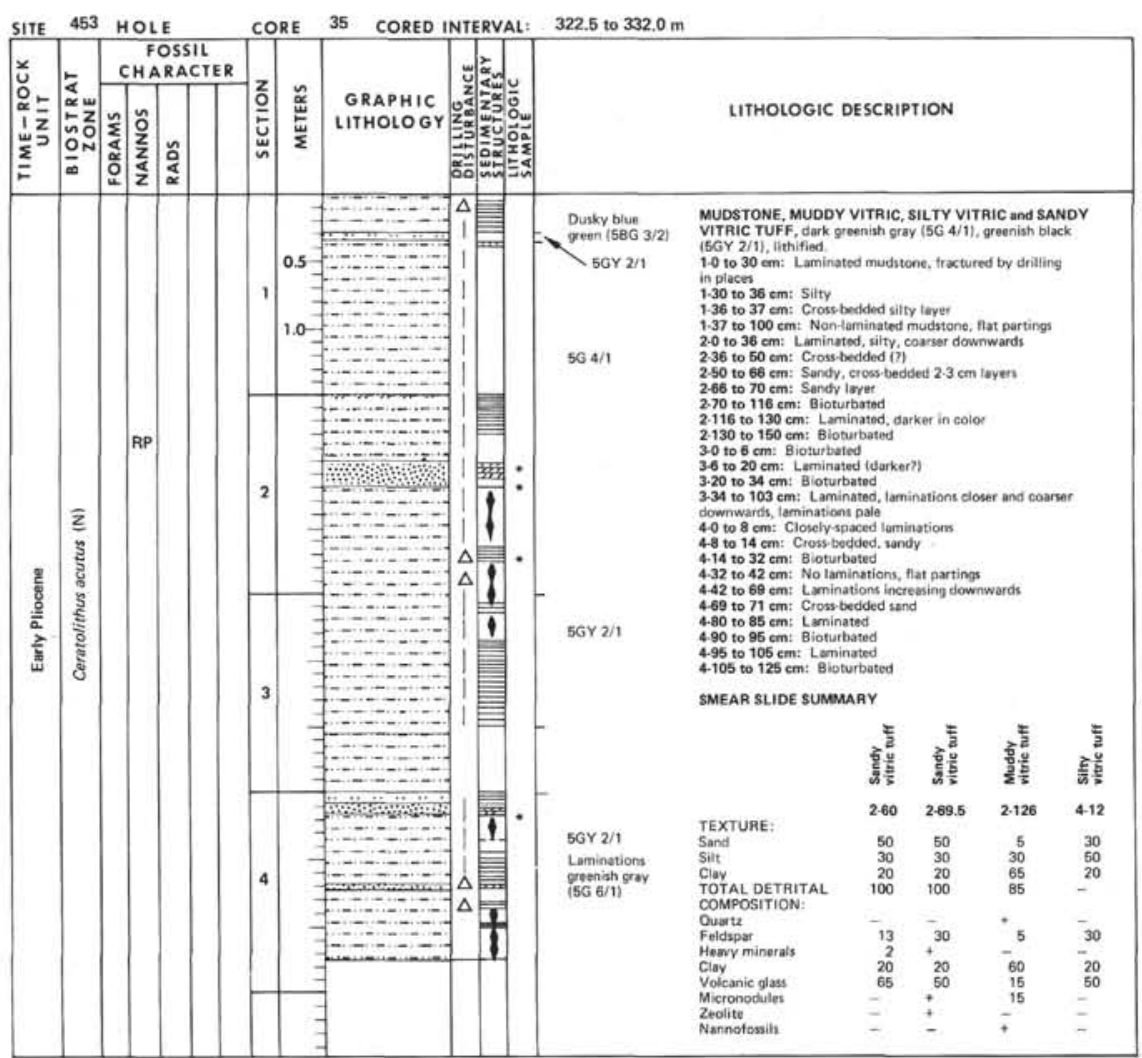

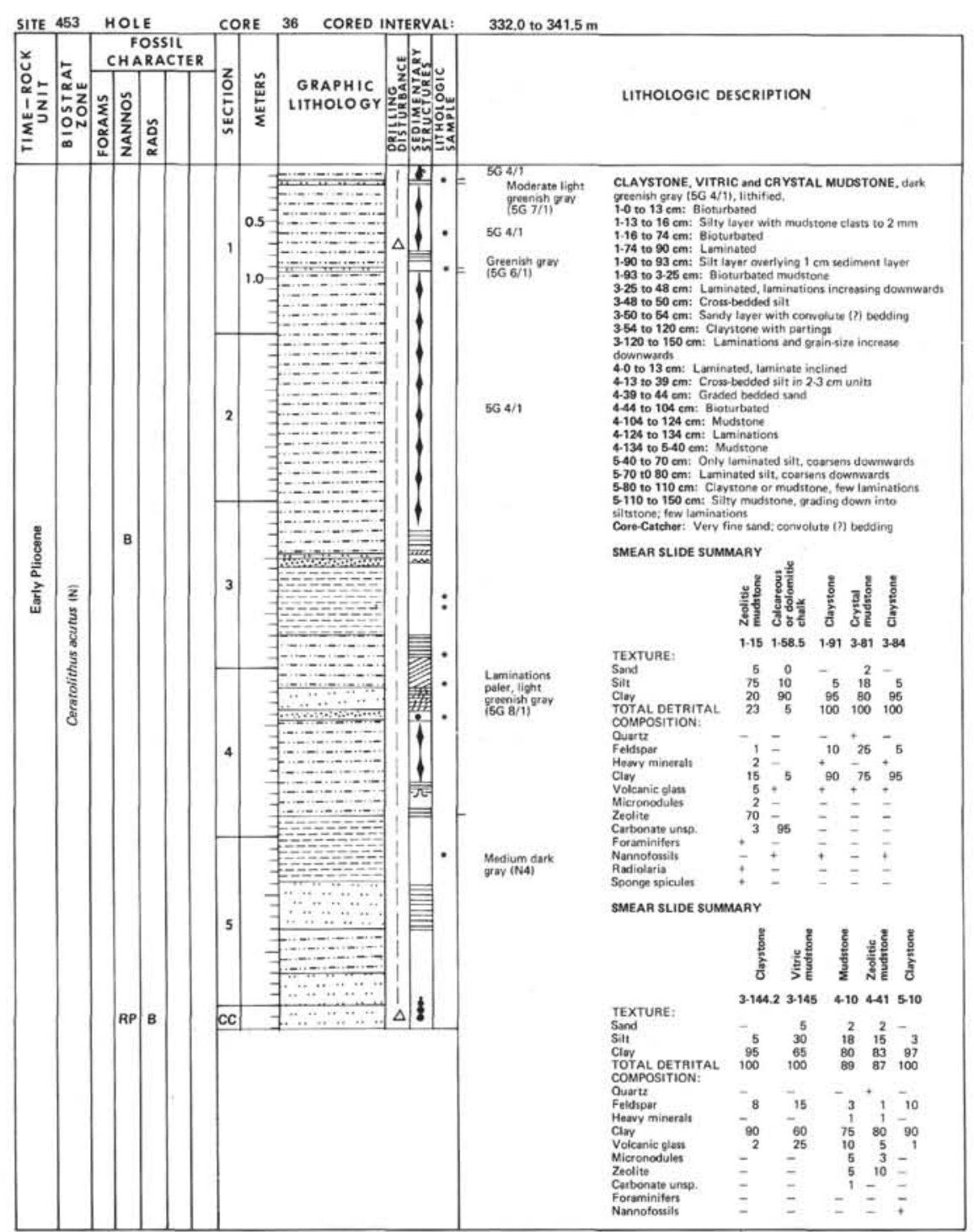




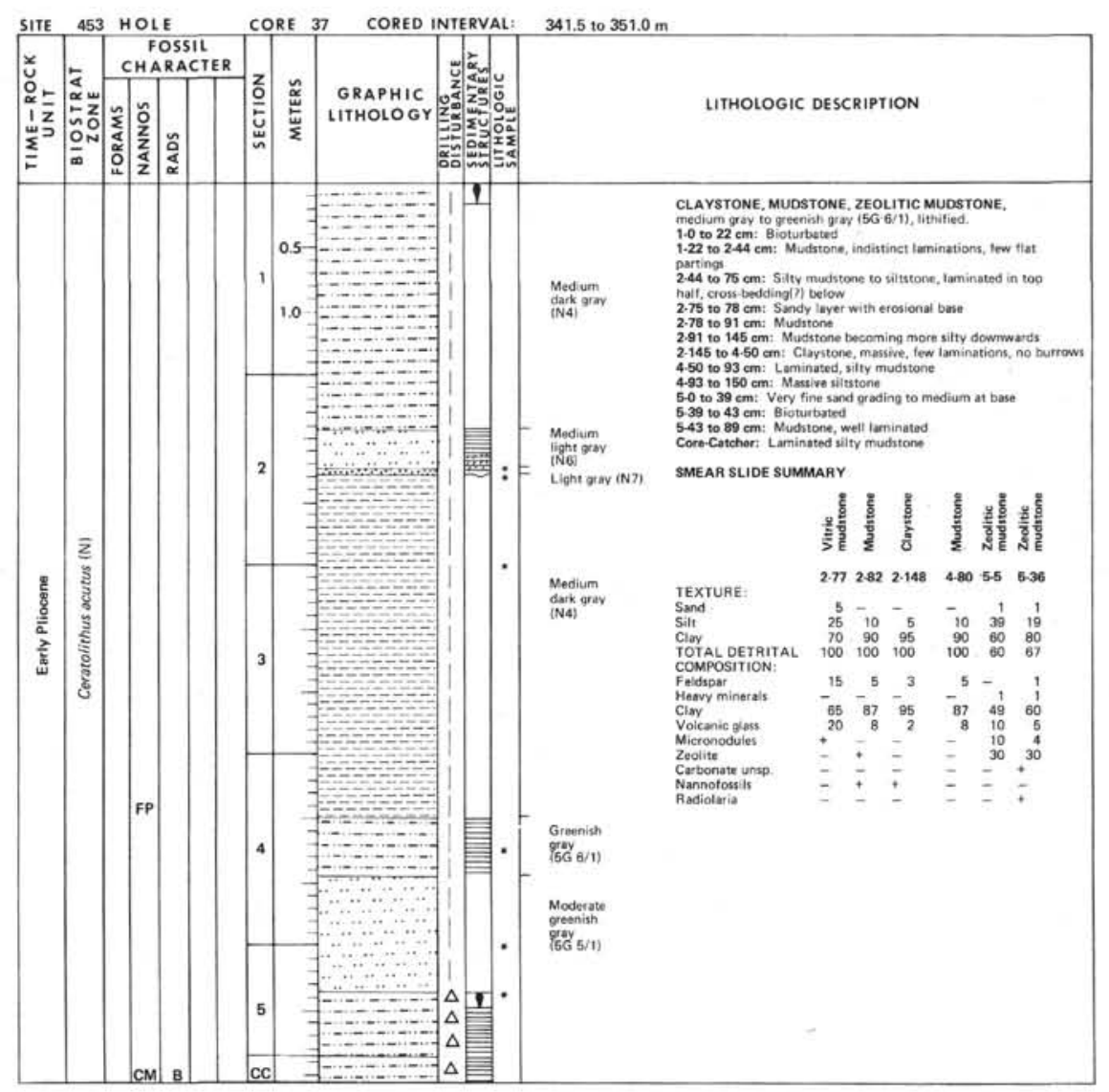

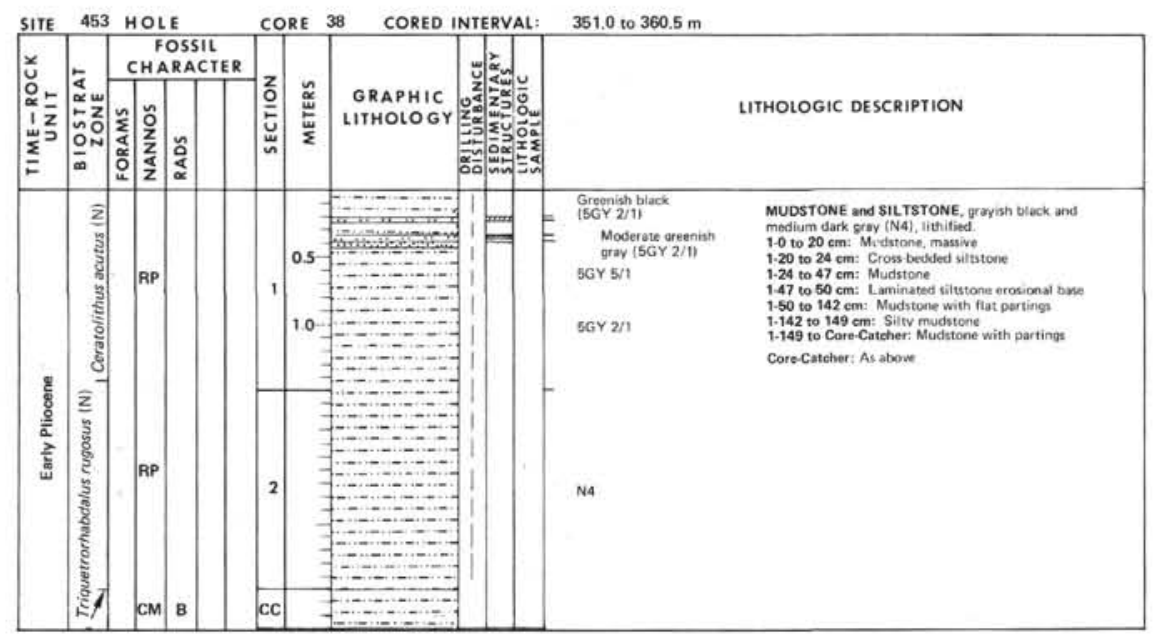




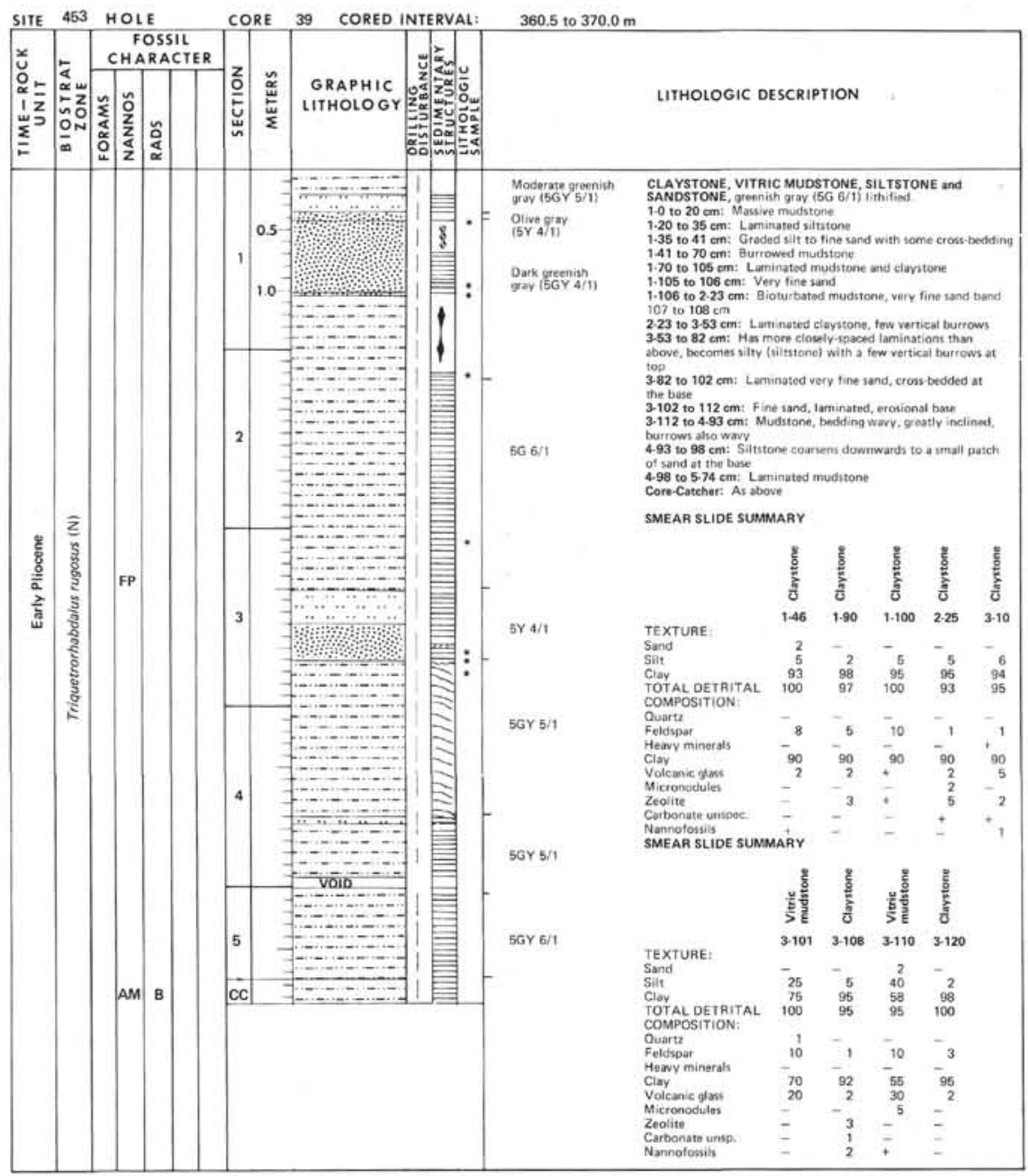

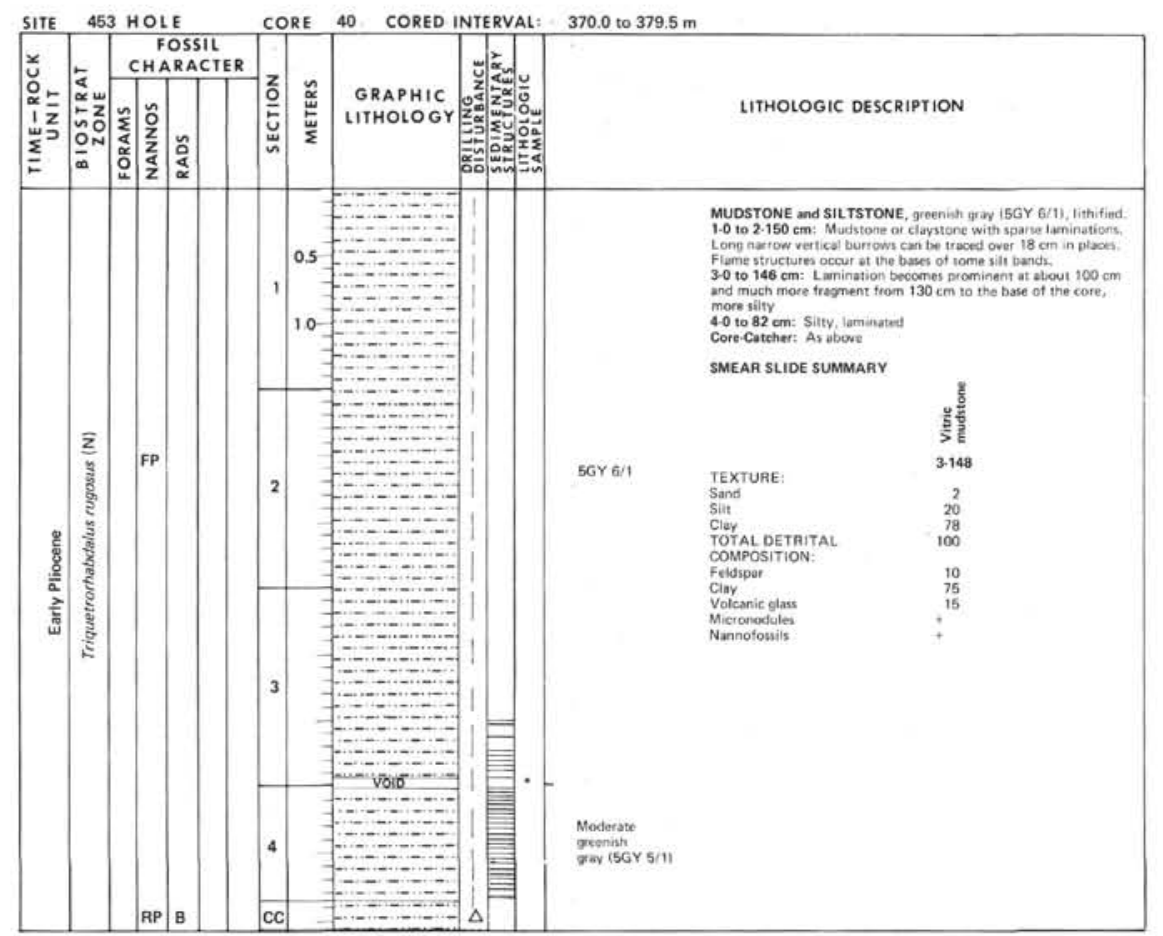




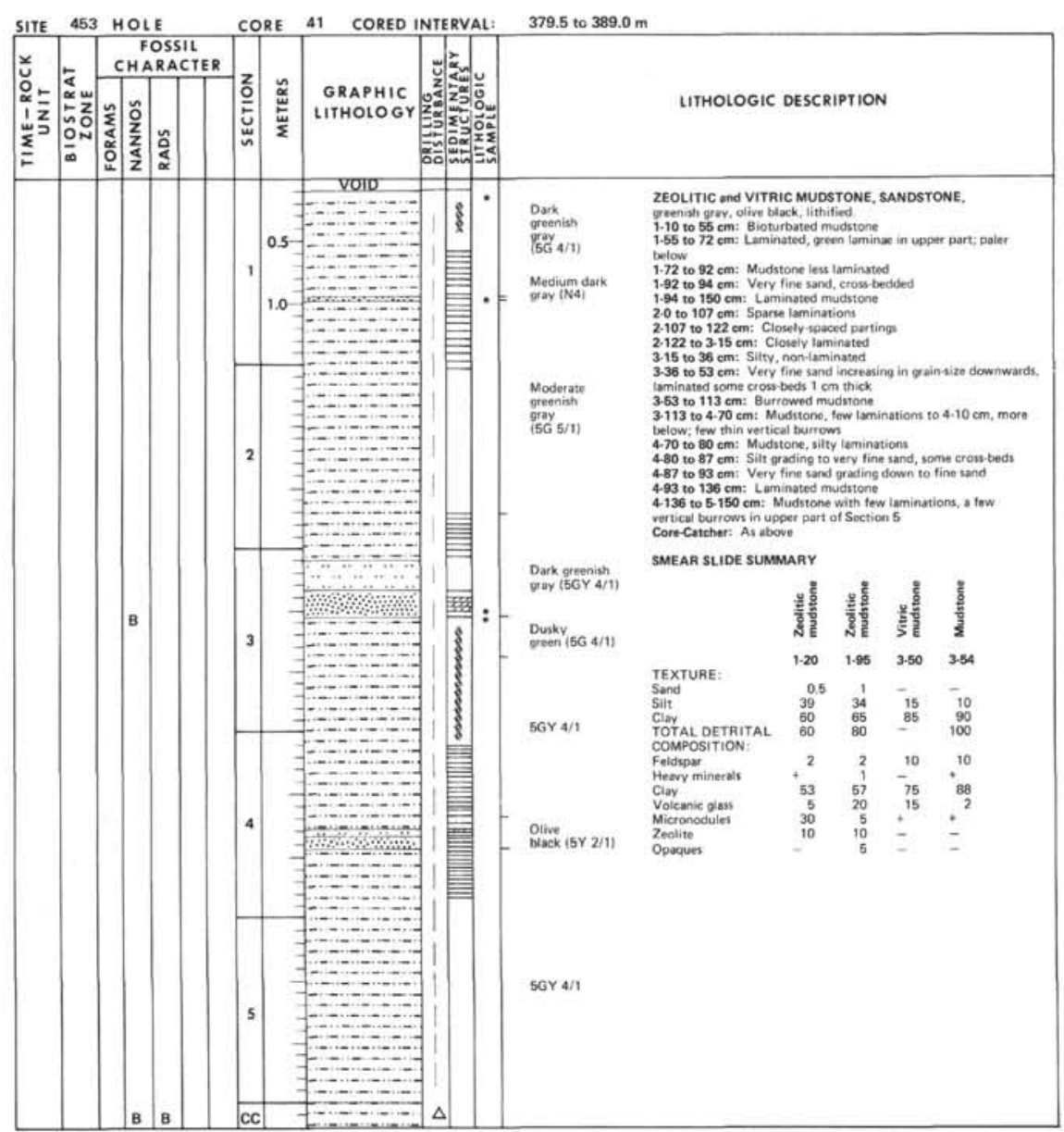

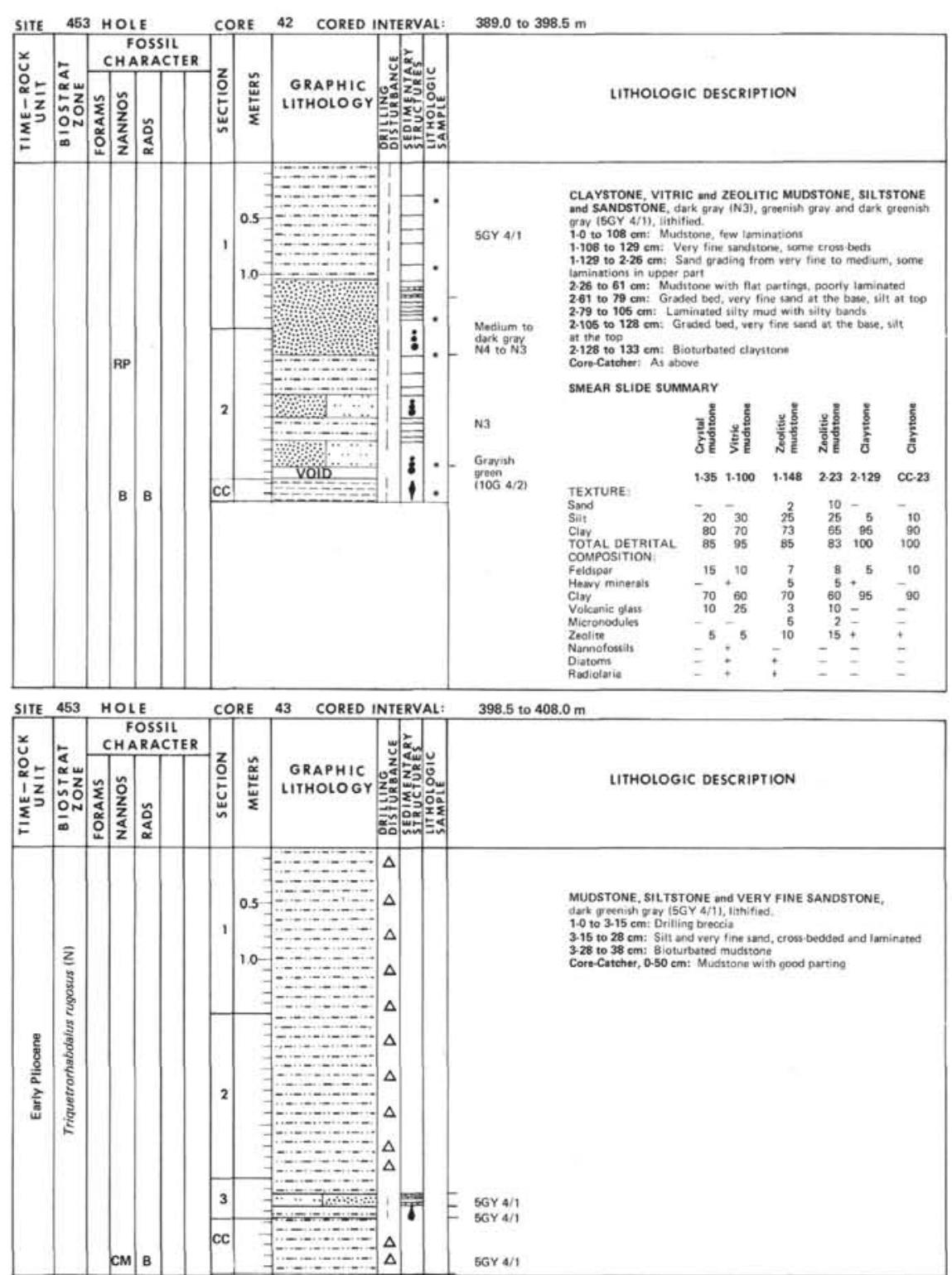




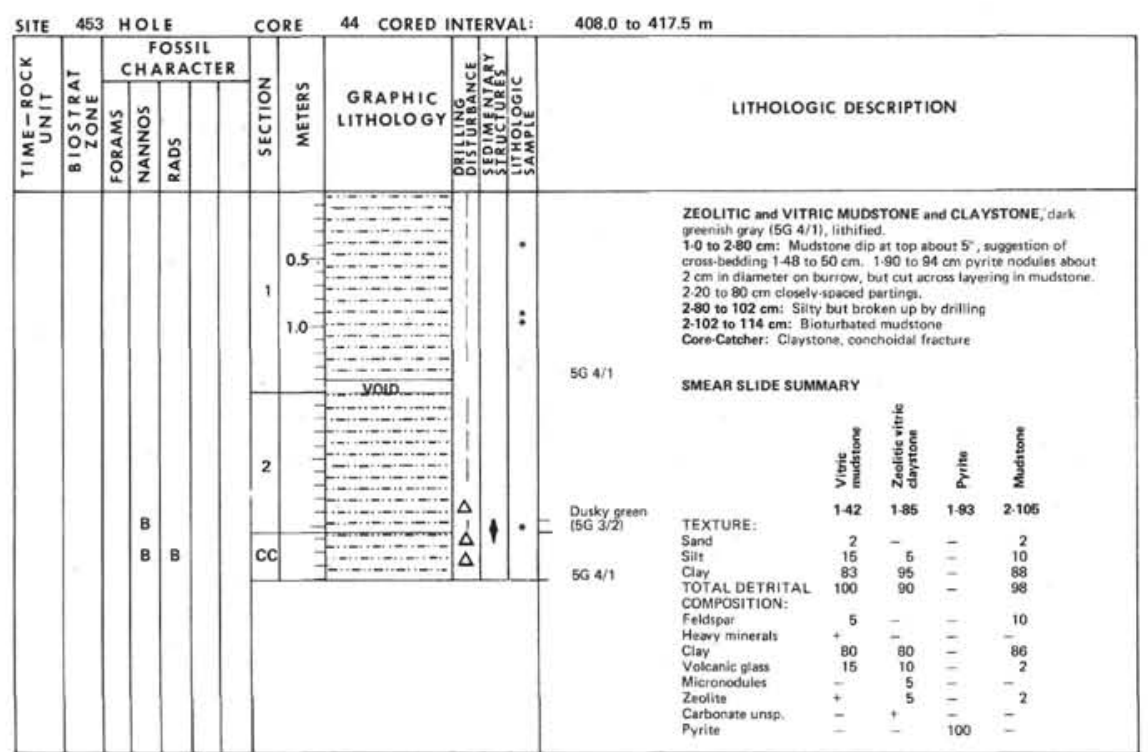

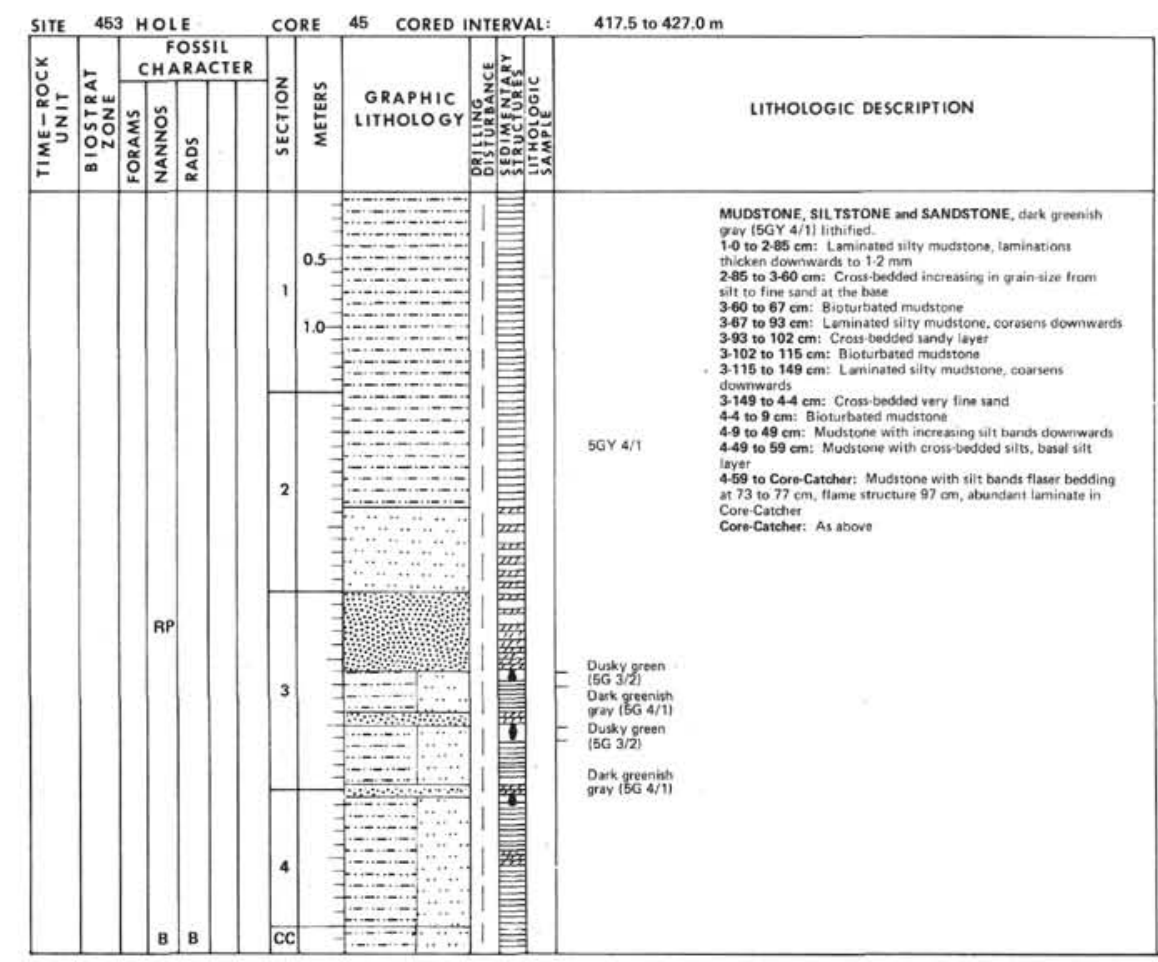




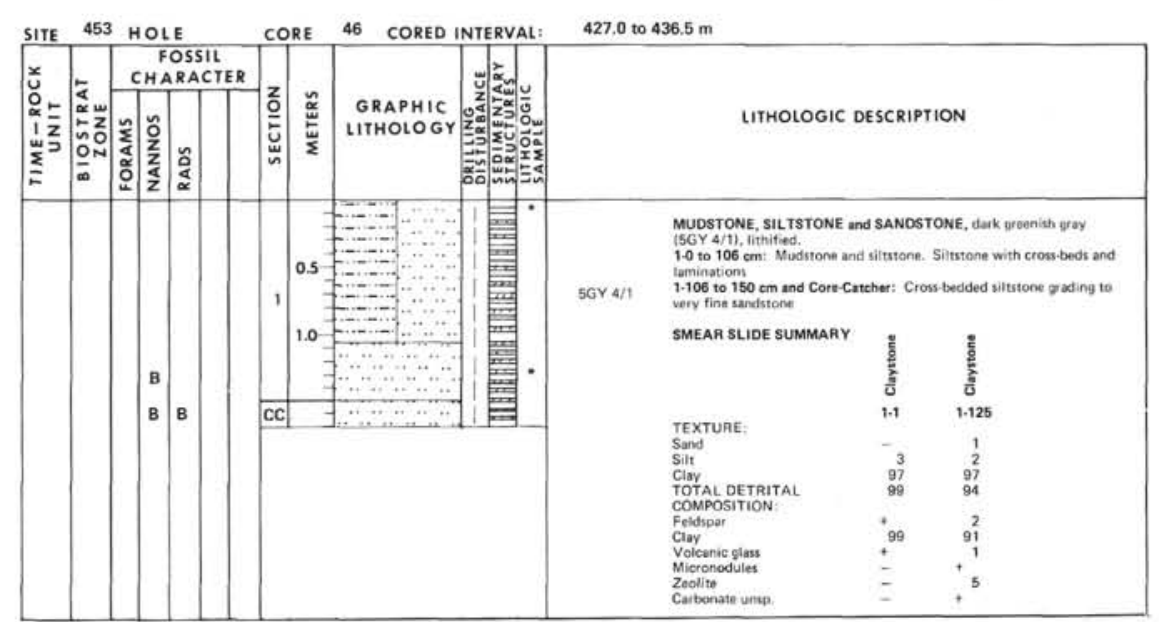

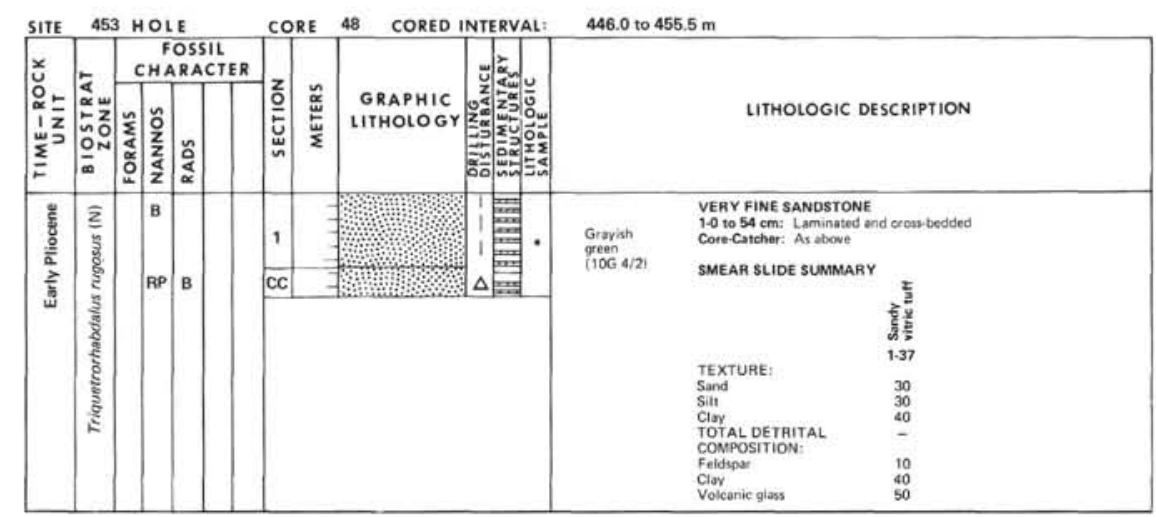

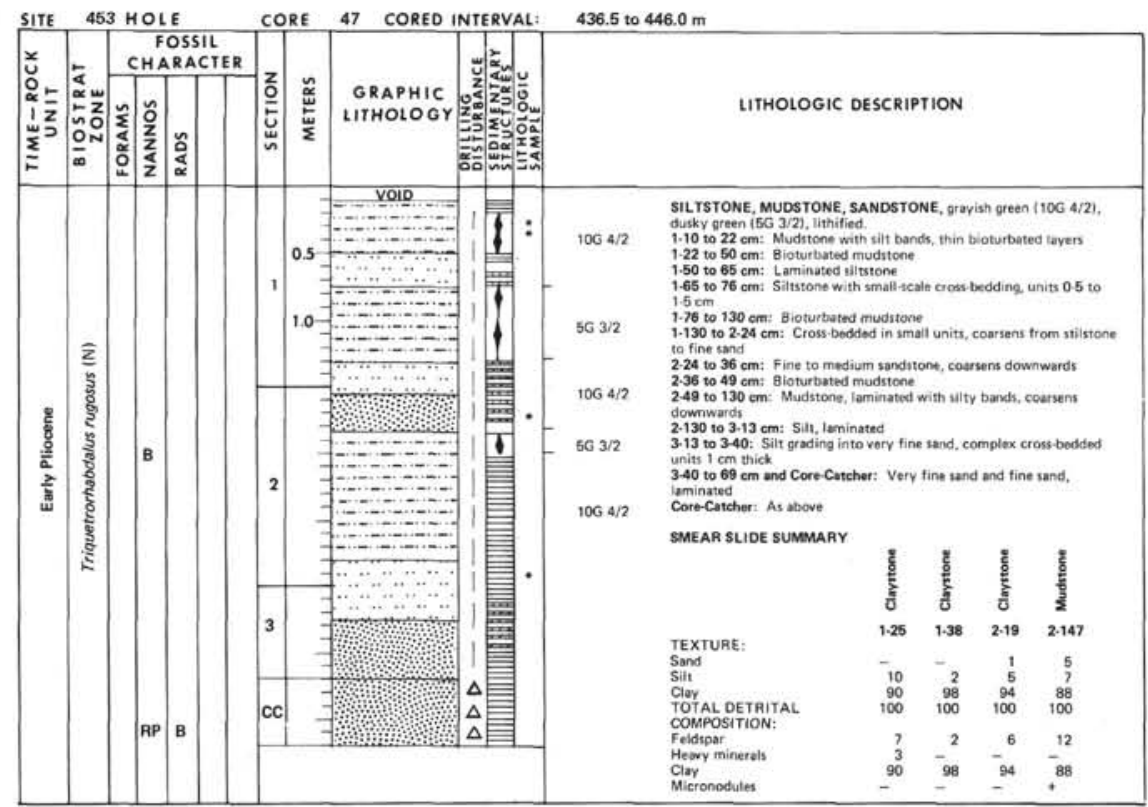




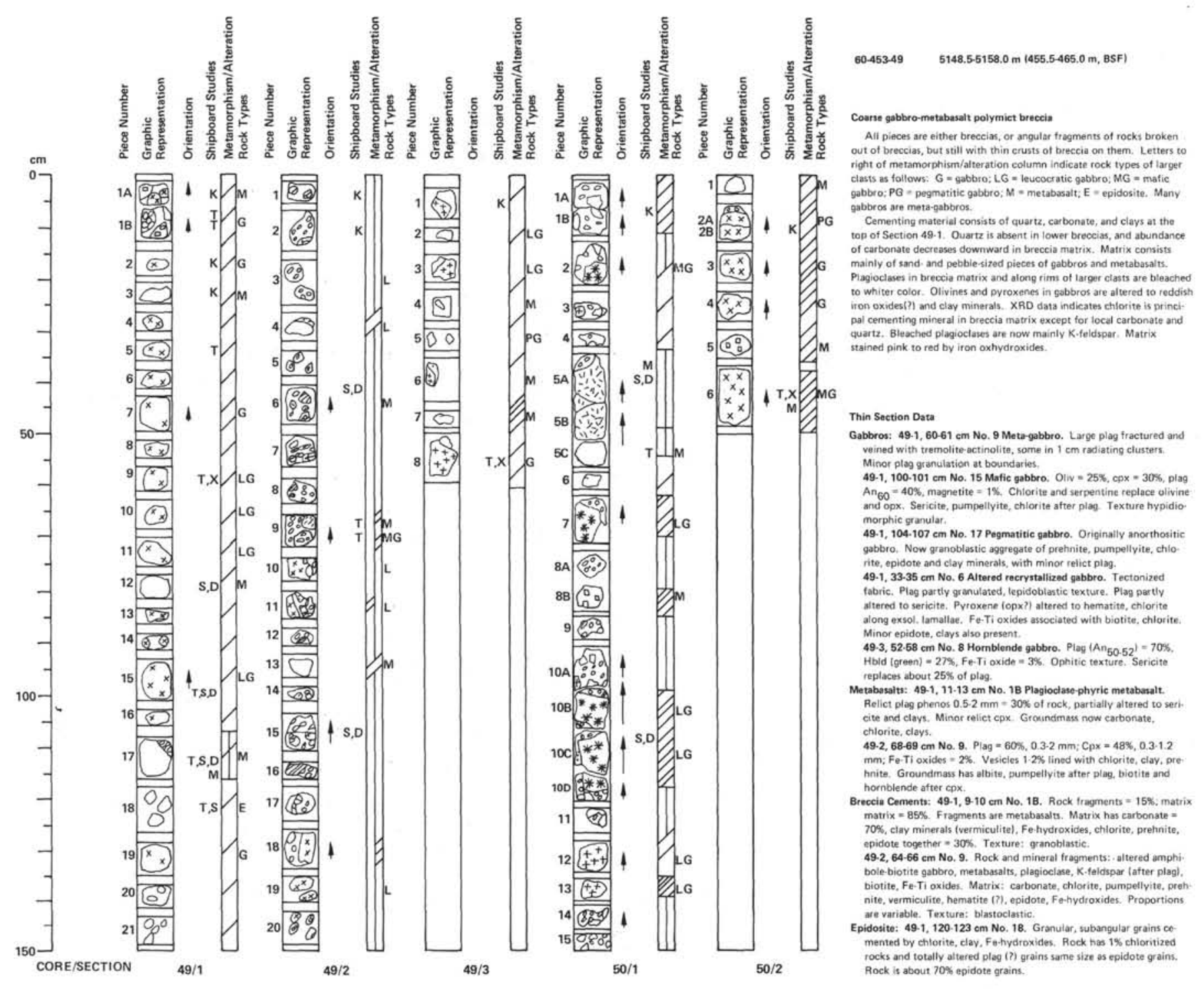

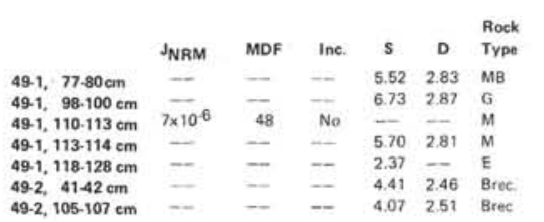

\section{$60.453 .50 \quad 5158.0-5167.5 \mathrm{~m}(4655.0-474.5 \mathrm{~m}, \mathrm{BSF})$}

Corne gabbro-metabasalt polymict breccis

. 49. Cement mainily carbonate and clays, with minor quartz. Sand and pebblesized rock and mineral grains make up most of breccia matrix.

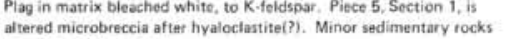
(mudstones?) in matrix.

Thin Section Data

Metabasalt: $50 \cdot 1,52.56 \mathrm{~cm}$ No. $5 C$. Very badly altered, previously vesicular with trachytic texture. Texture granoblassic, anygda.
loidal. Amygdules $=5 \mathrm{~S}$, consisting of chlorite, prehnite, qtz, and carbonate, Groundmass - $-95 \%$, consisting of prehnite(?), pumpelly

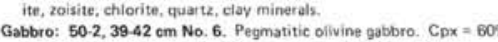
olivine $=15 \%$, plagioclase $=25 \%$. Texture: poikilitic. Olivine of cracks, the first filled with actinolite, the second with serperation chlorite.

JNRM MDF Inc. $S$ D $\begin{aligned} & \text { Rock } \\ & \text { Type }\end{aligned}$

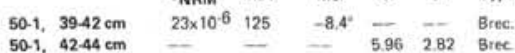

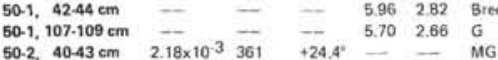




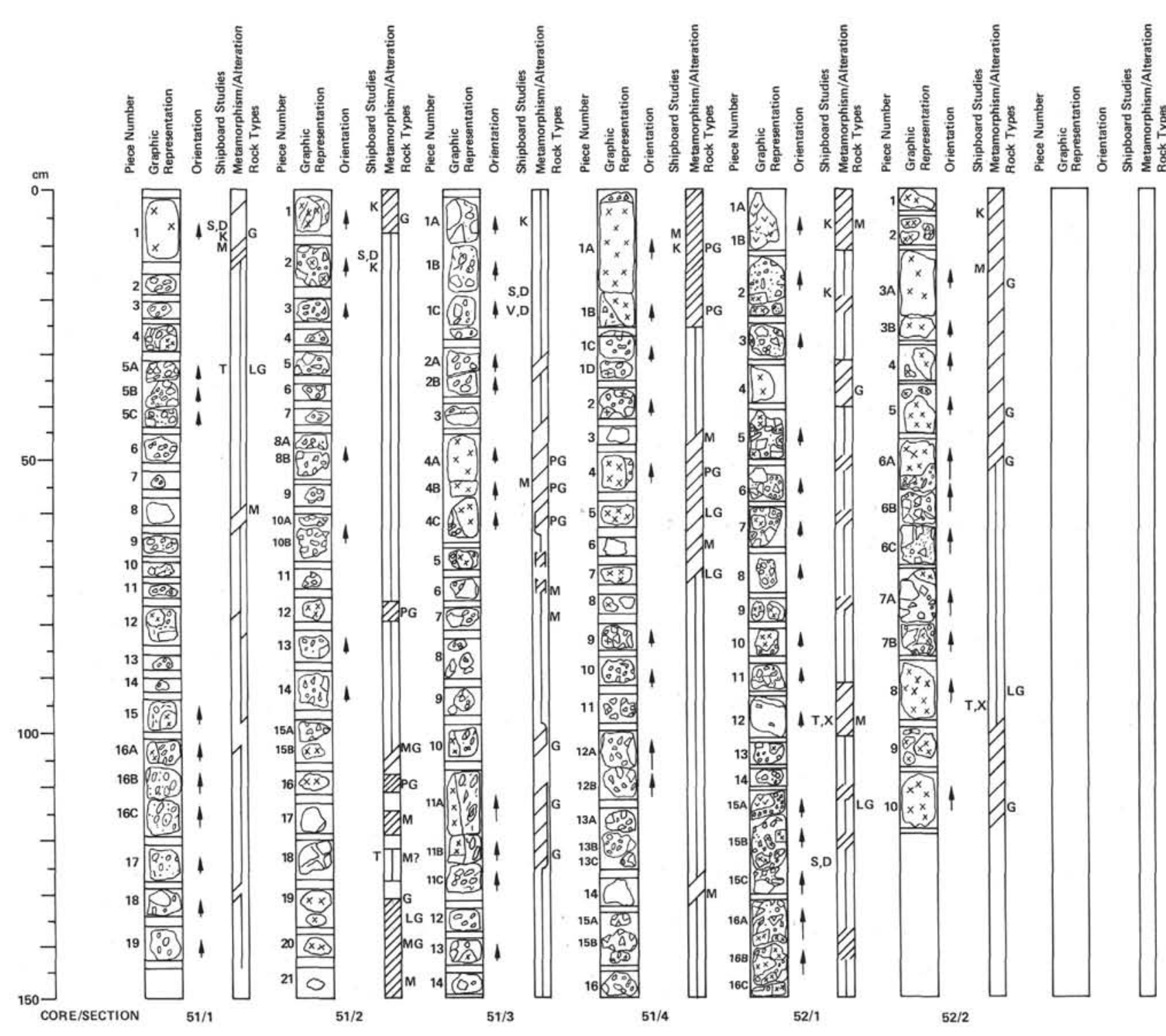

60.453.51 5177.5.5187.0 m (4474.5.484.0 m, BSF)

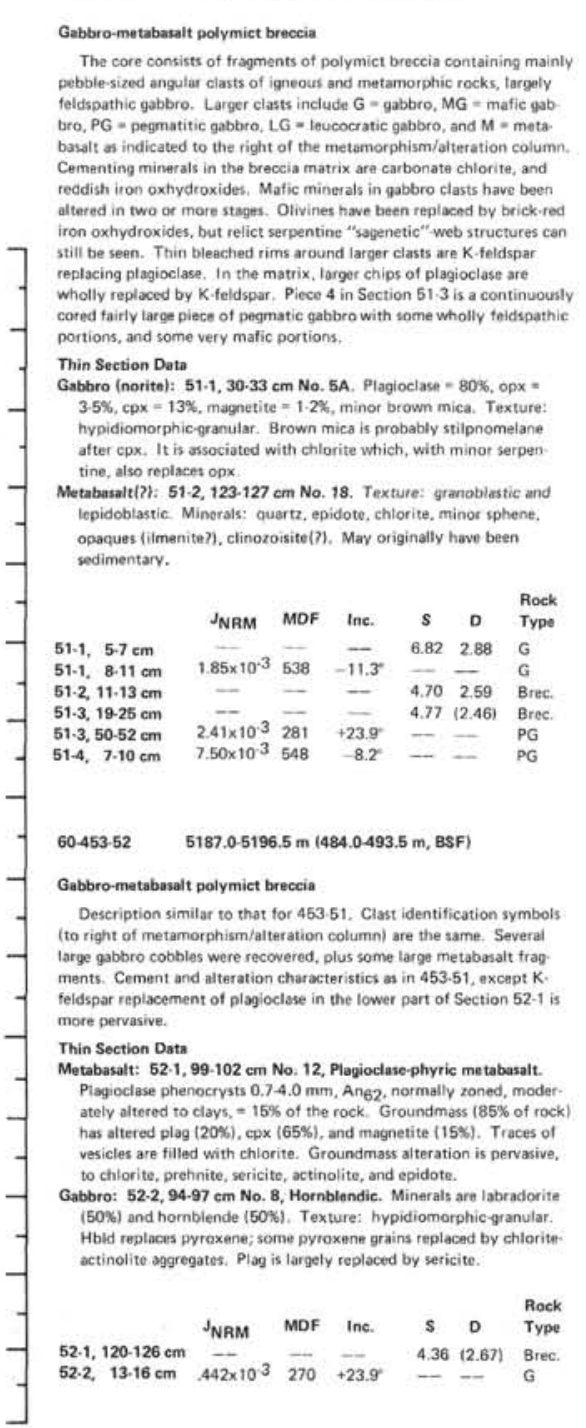




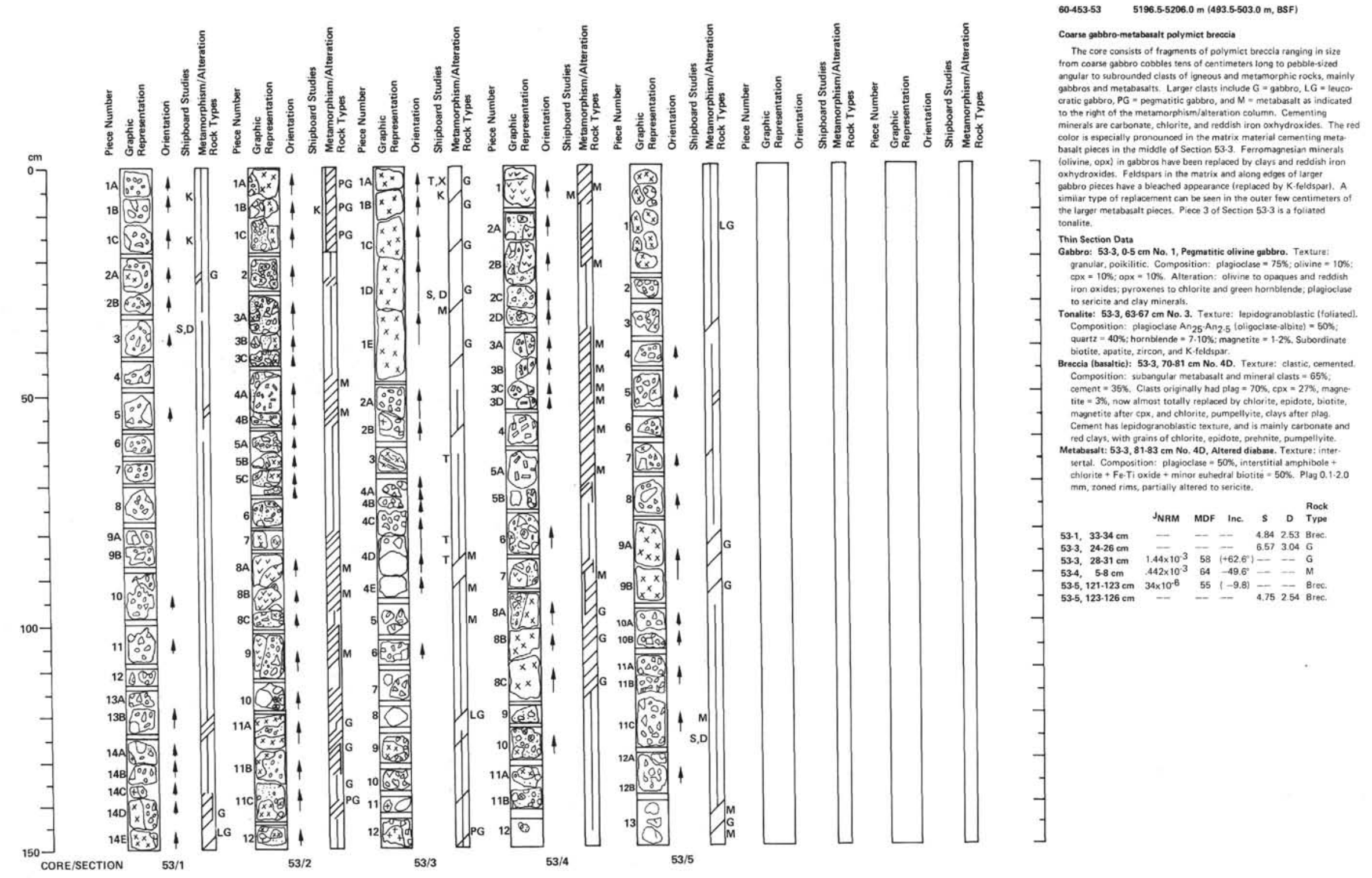




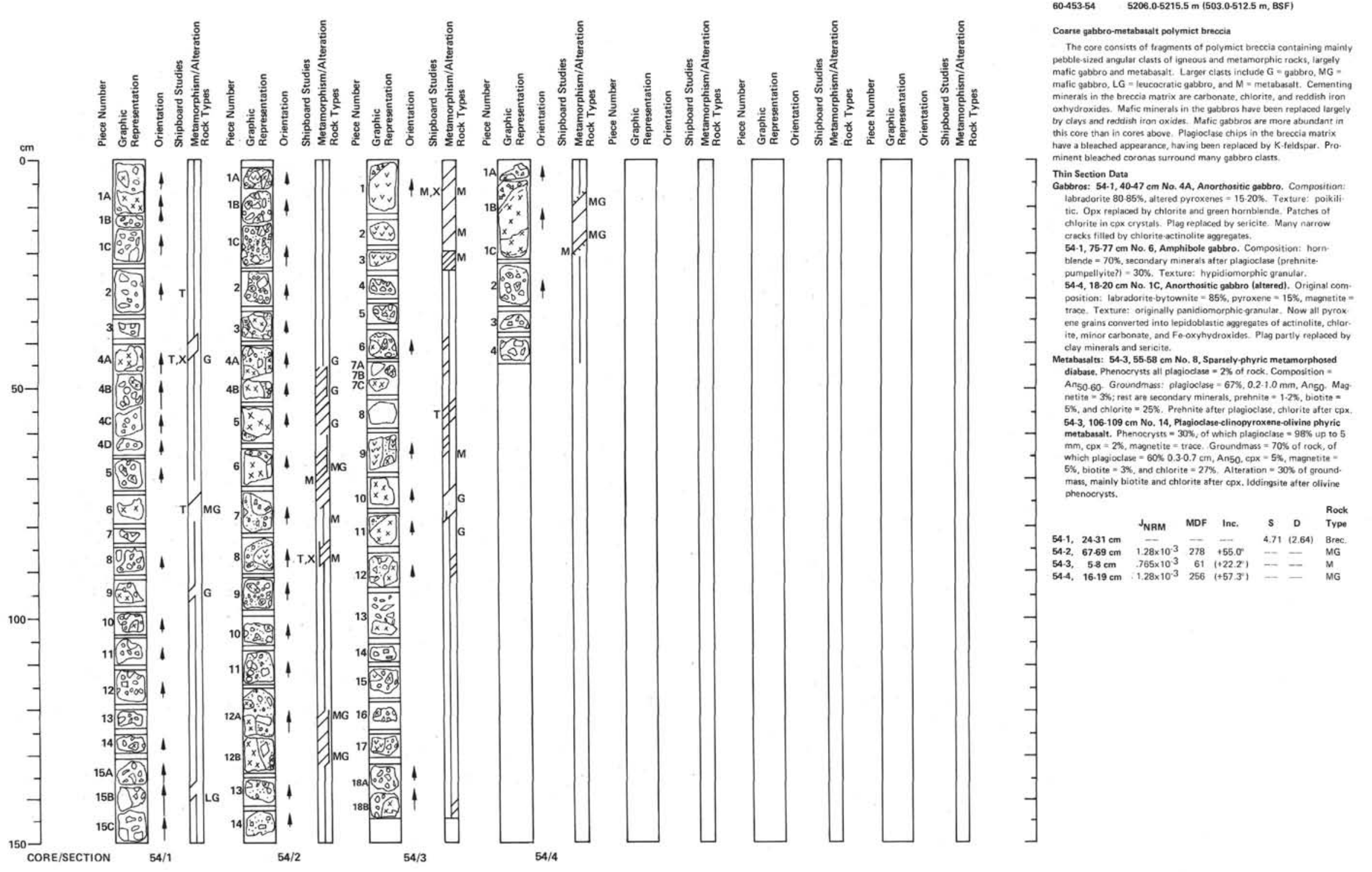




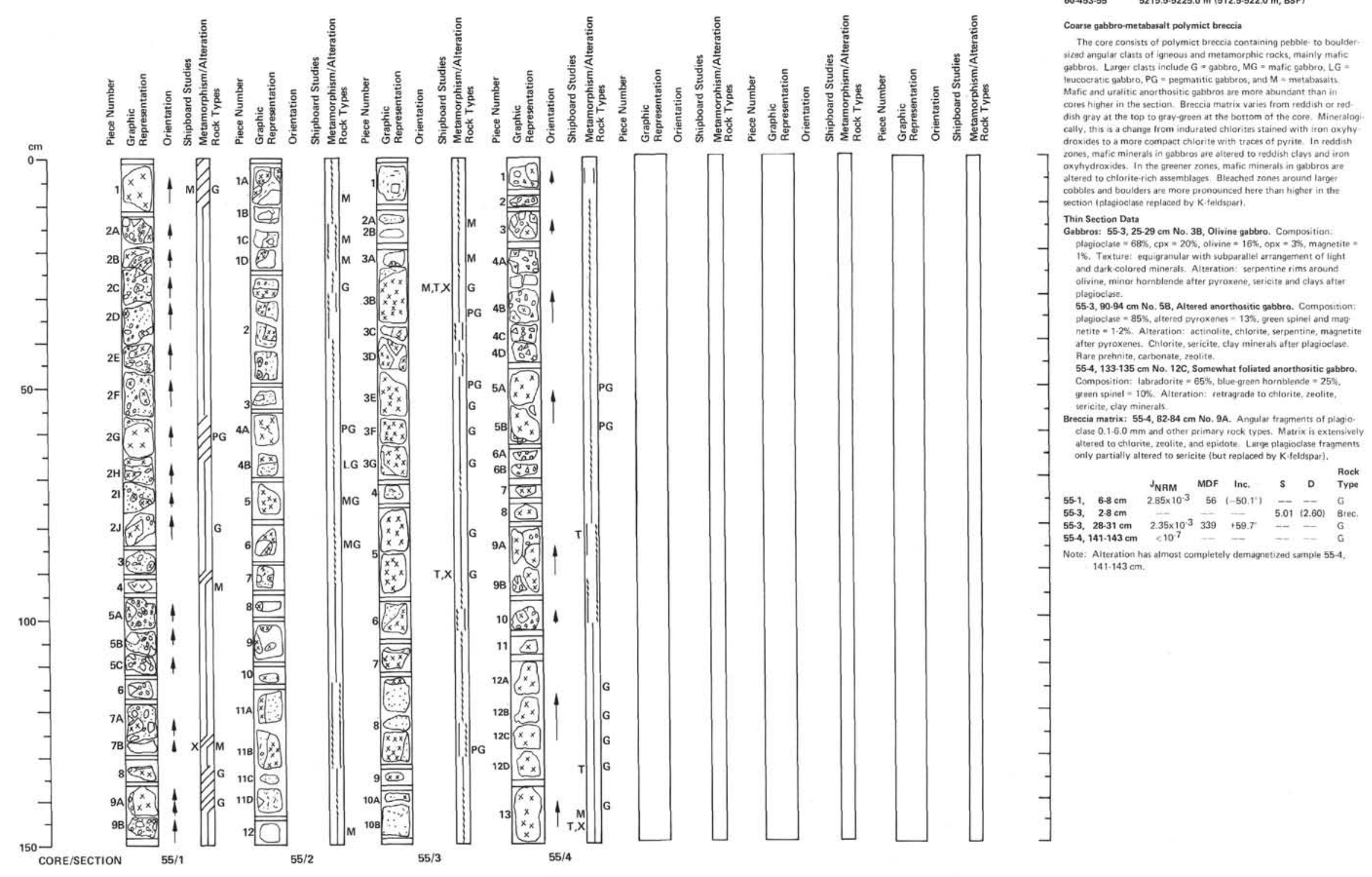




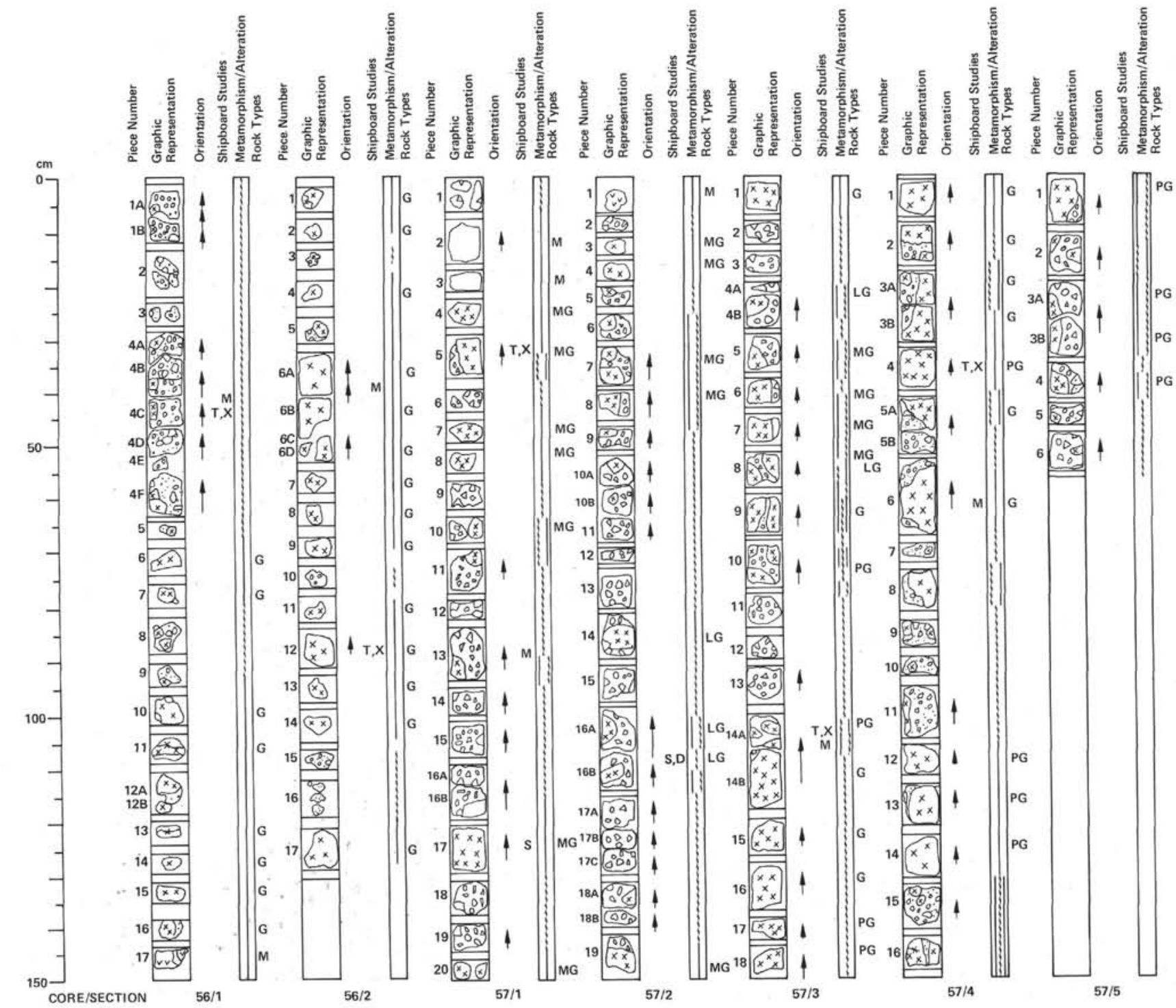

60.453.56 5225.0.5234.5 m $1522.0 .531 .5 \mathrm{~m}$, BSF

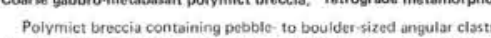

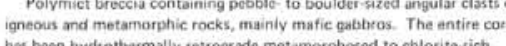
has been hydrothermally retrograde metamorphosed to chlorite-rich

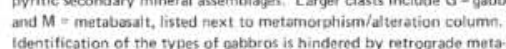
morphism. The Matrix is gray-grof

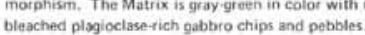

\section{Thin Section Date}

Gabbros: 56-2, 33-35 cm No. 6A, Altered anorthositic gabbro. Comnetite $=10 \%$. Texture: granular

picioclose partly con pumpellyite. Mafic minerals repiliced by chlorite, actinolite, and epidote

$56-1,38.40 \mathrm{~cm} \quad J_{\text {NRM }}$ MDF Inc. S D $\begin{aligned} & \text { Rock } \\ & \text { Type }\end{aligned}$

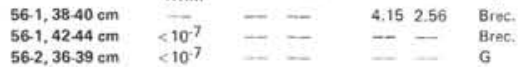
Note: Samples in this core have been
by hydrothermal alteration

Gy

60.453.57 5234.5.5244.0 m (531.5.541.0 m, BSF)

ade metamorphosed

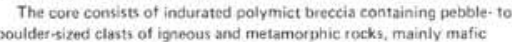
gobbros. All of the core but a portion of the lower two sections has bearing mineral assembiagos. Larger clasts include $G=$ gabbro, $M G$ : mafic gabbro, $L G=$ leucocratic gabbro, and PG = pegratitic gabbro. Metabasalts are minor, making the breccia viftually monomict in placer.

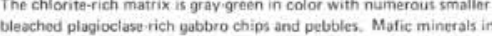
the gabbros are altered to chloritic assembliages. Traces of the priginality brown-colored brectia mathix still persist in Sections 4 and 6.

Thin Section Data

Gabbros: $57.3,10.12 \mathrm{~cm}$ No. 2, Troctolite. Composition: Bytownite = granular, cumulatse. Alteration: ollvine replaced by sementine. chlorite and magnetite, plagioclase by sericite and clay minerals $57.4,33.36 \mathrm{~cm}$ No. 34 , Pegmatitic olivine anorthositic gabbra netite $=25$. Texture: poikilitic, granular. Alteration: Matic

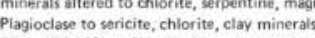

(a) magnetite = 2\%. Texture: poikilitic. Alteration: moderate: serpentine de

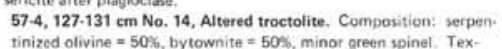

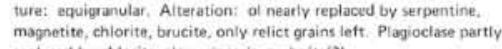

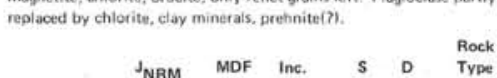

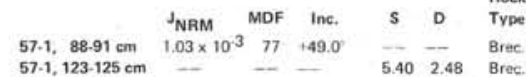

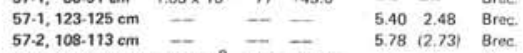

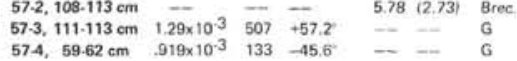




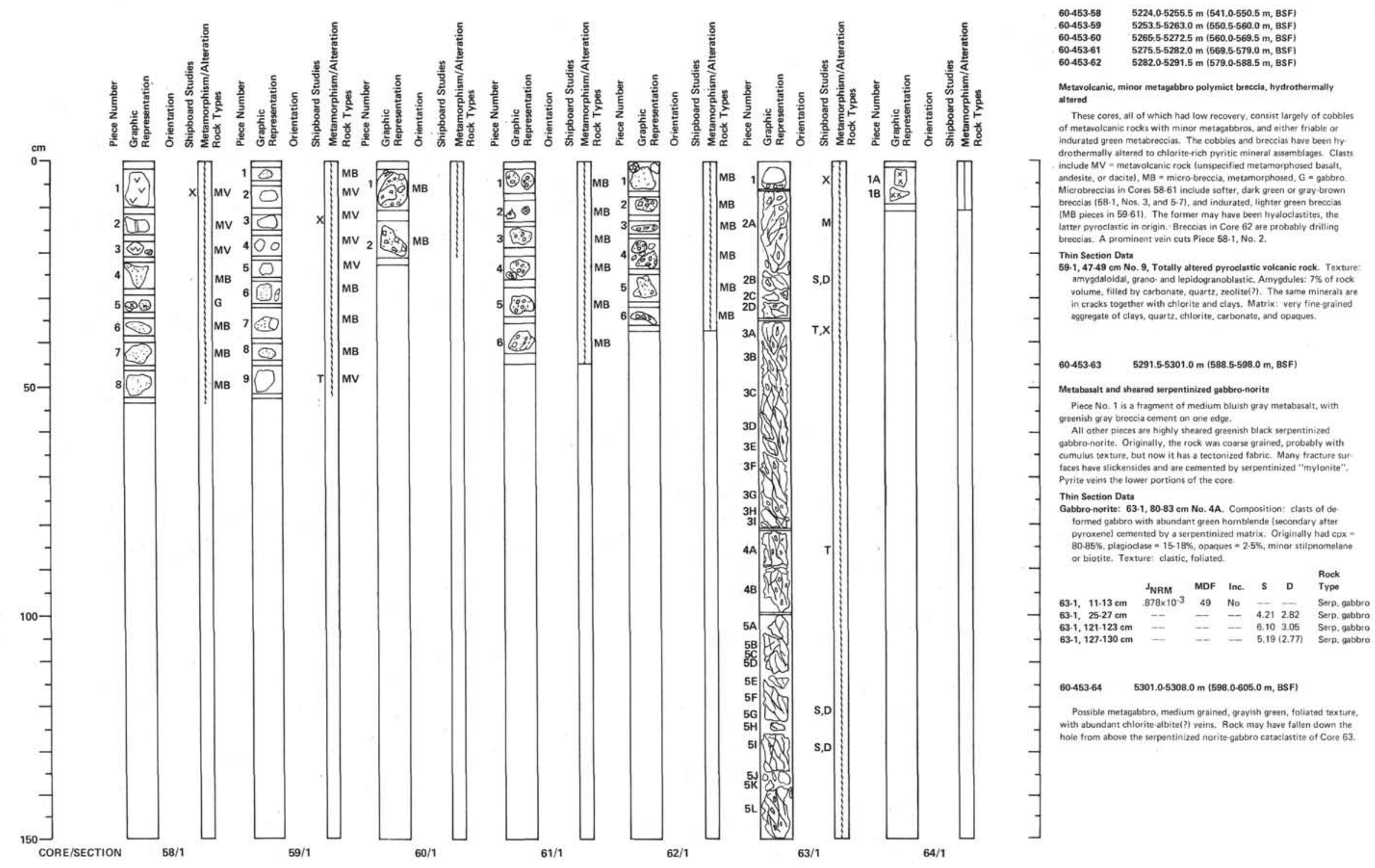




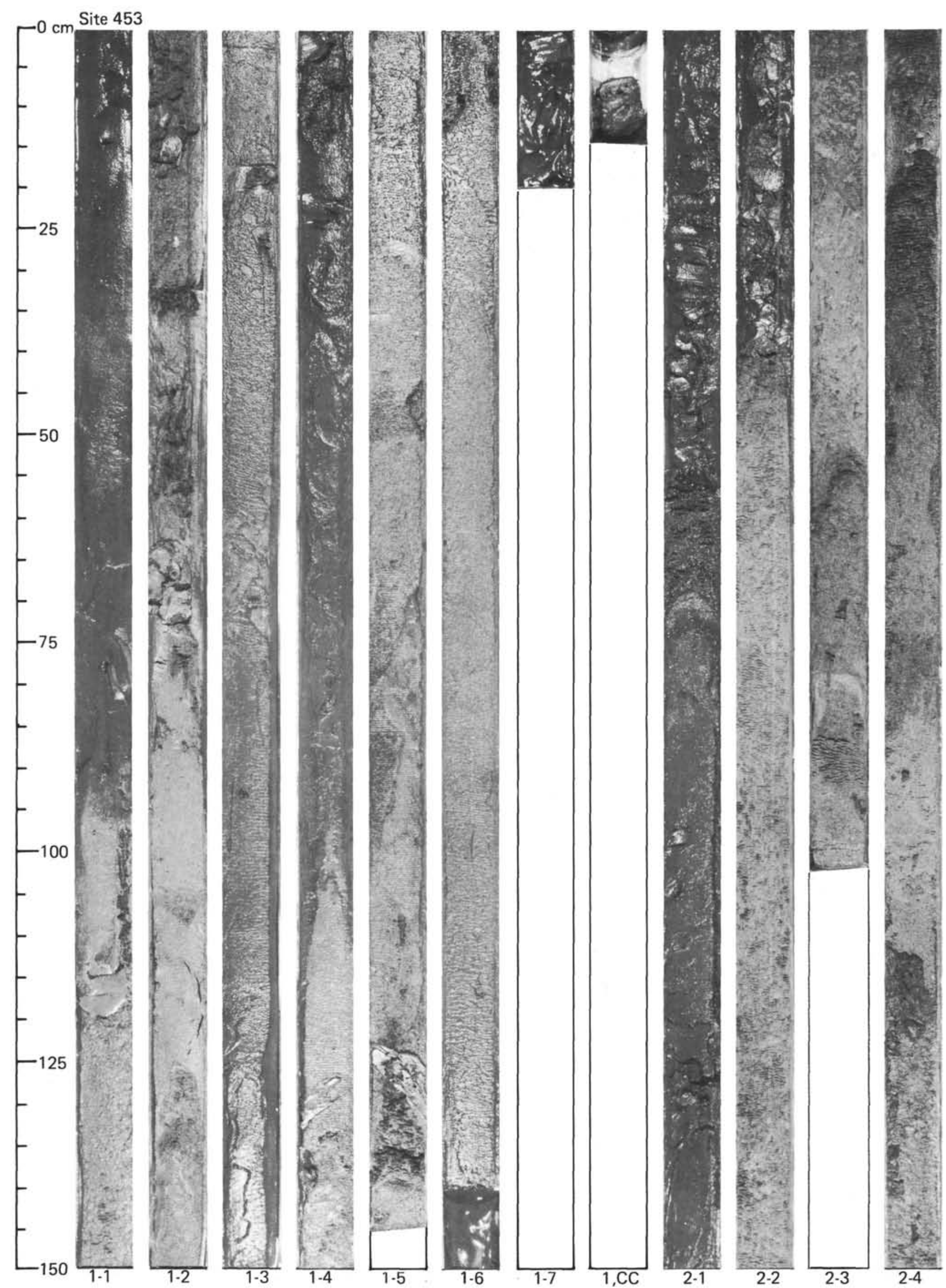




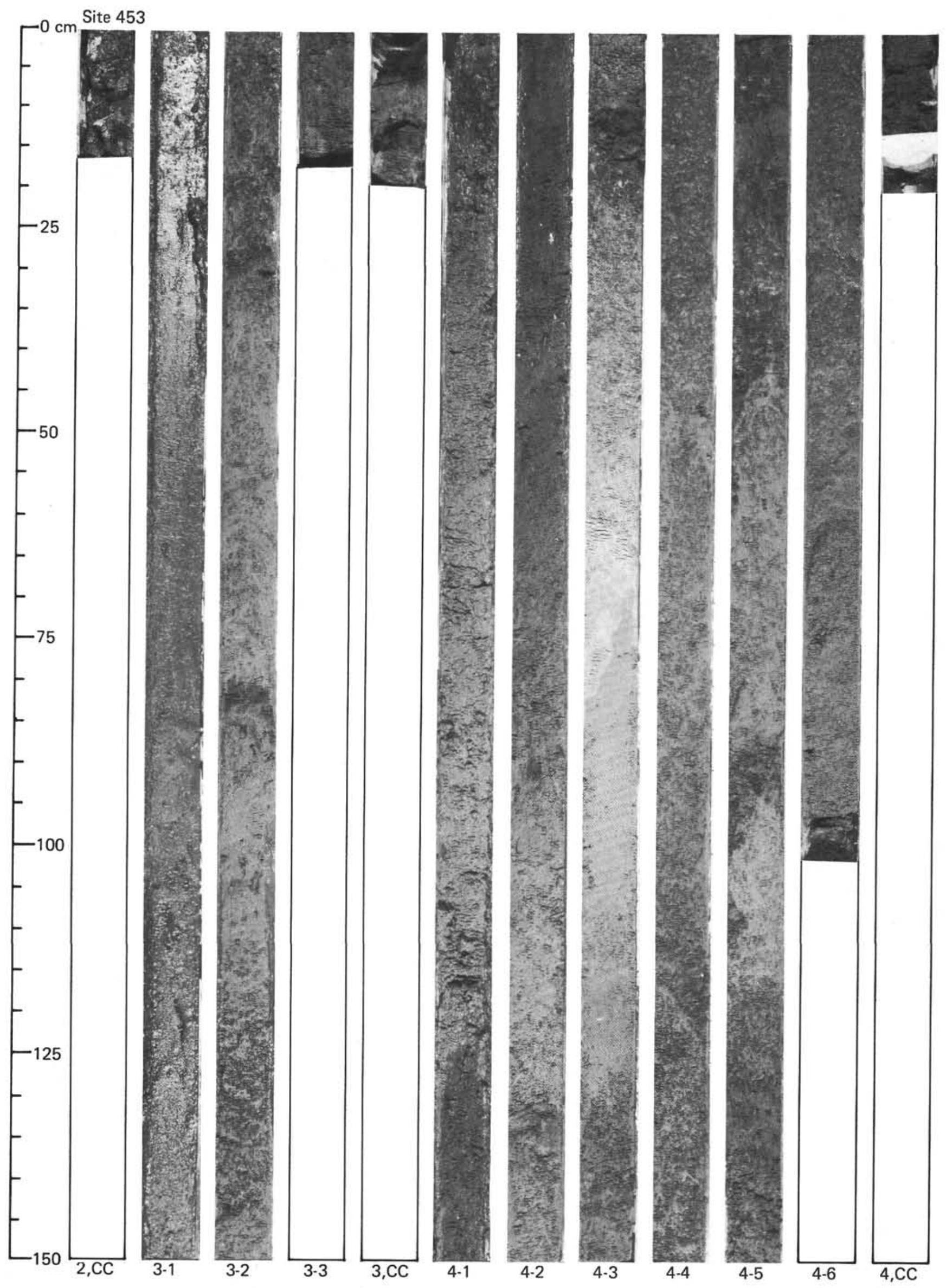




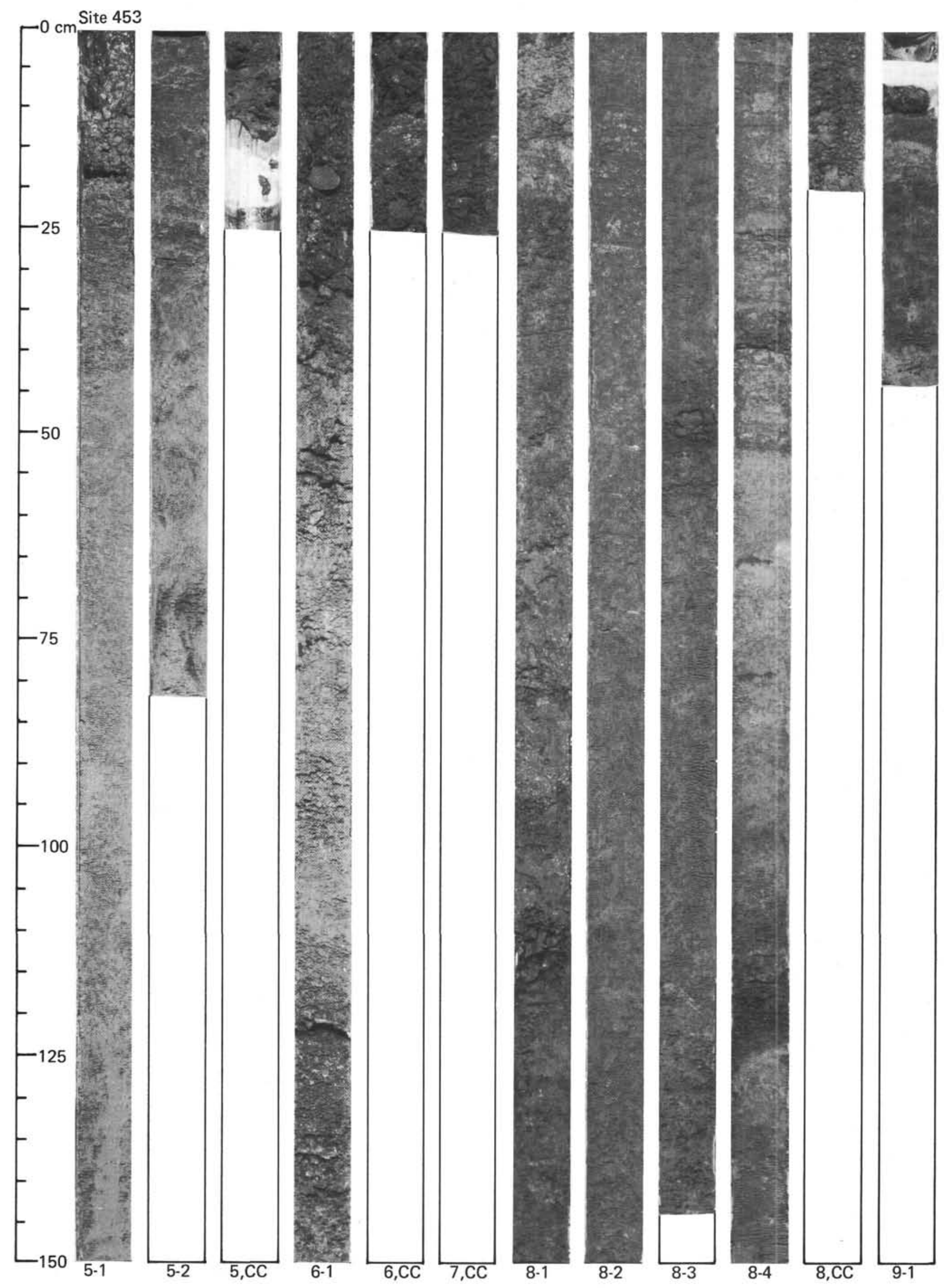


Site 453

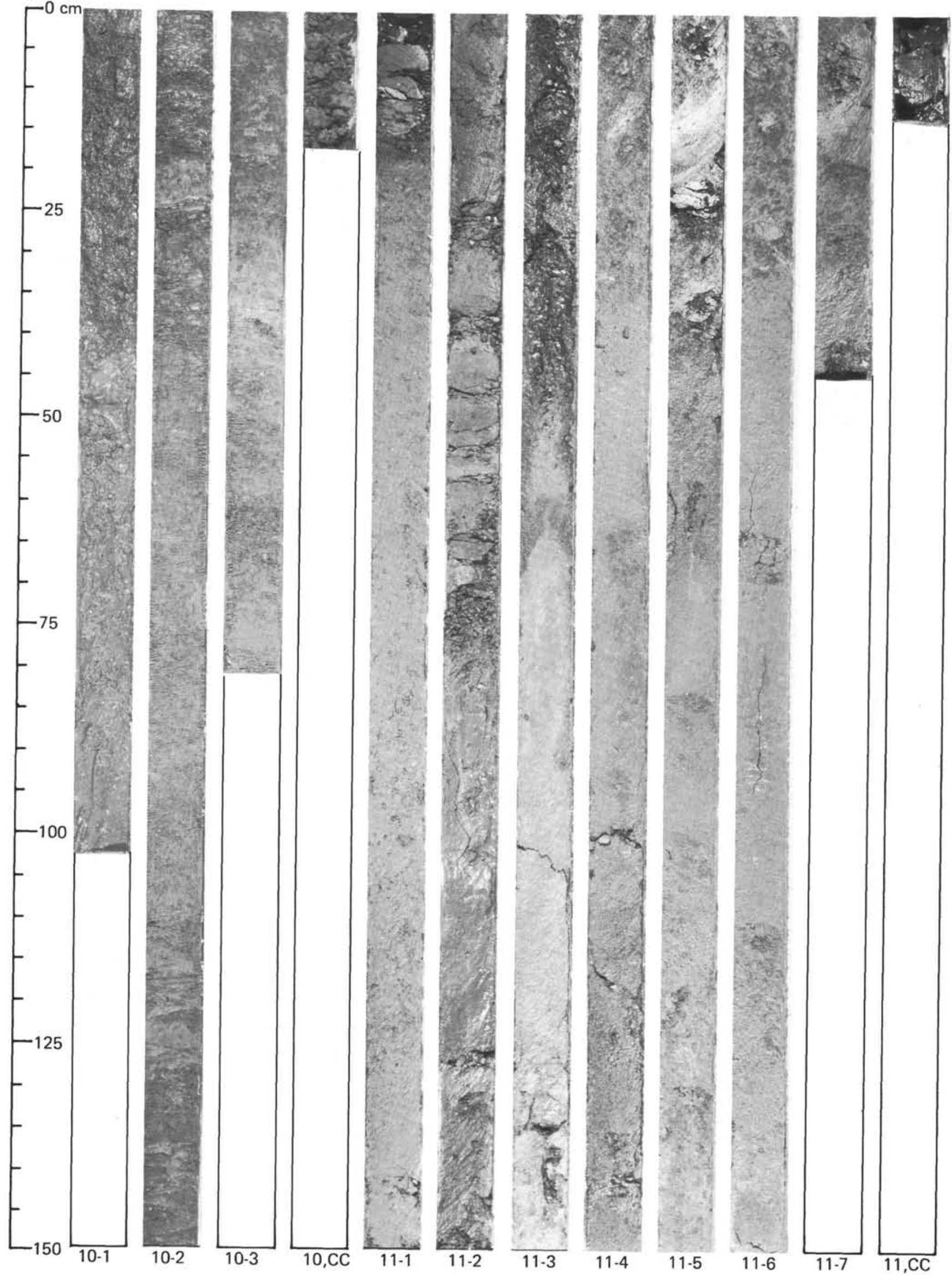


Site 453

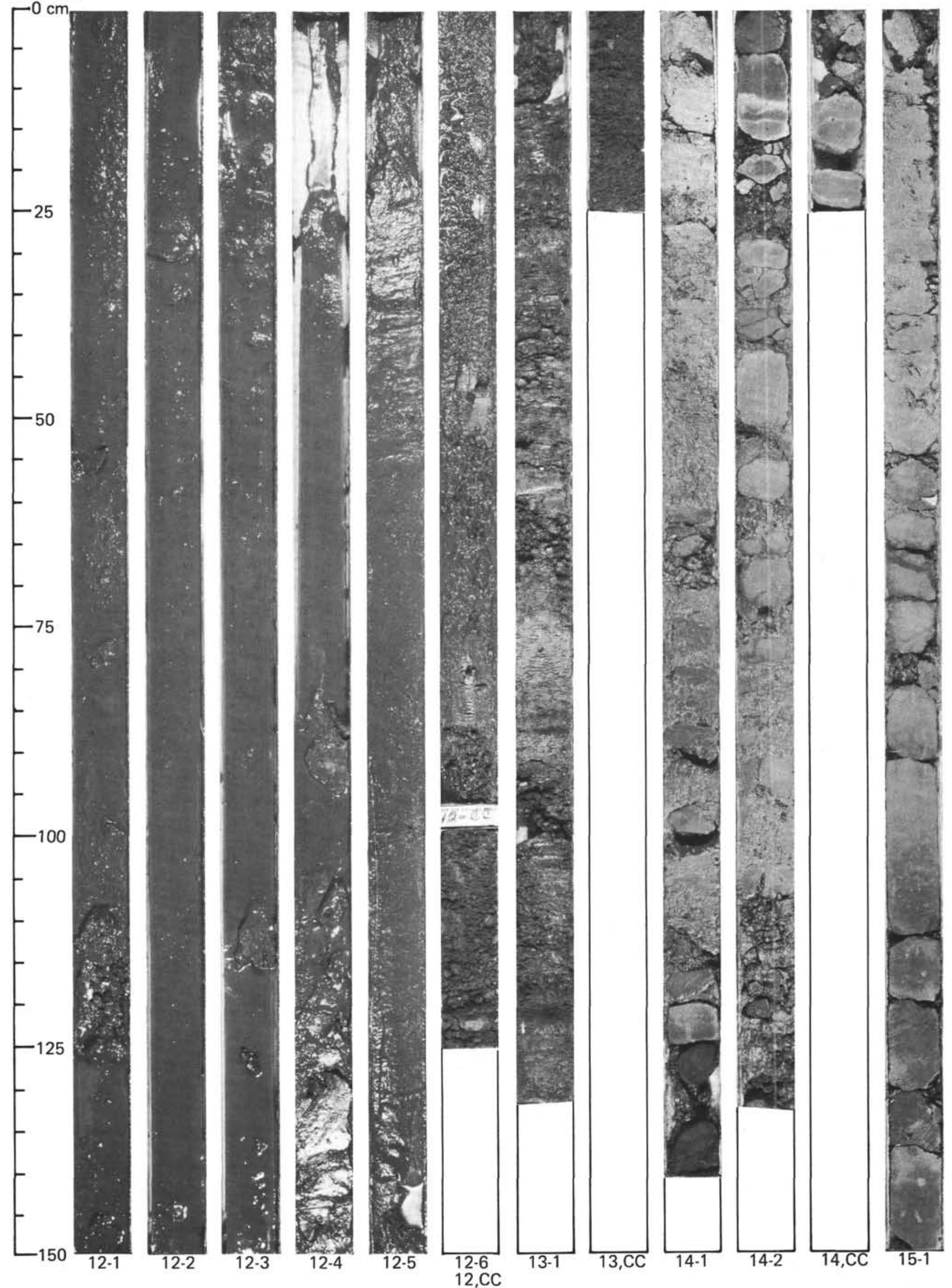


Site 453

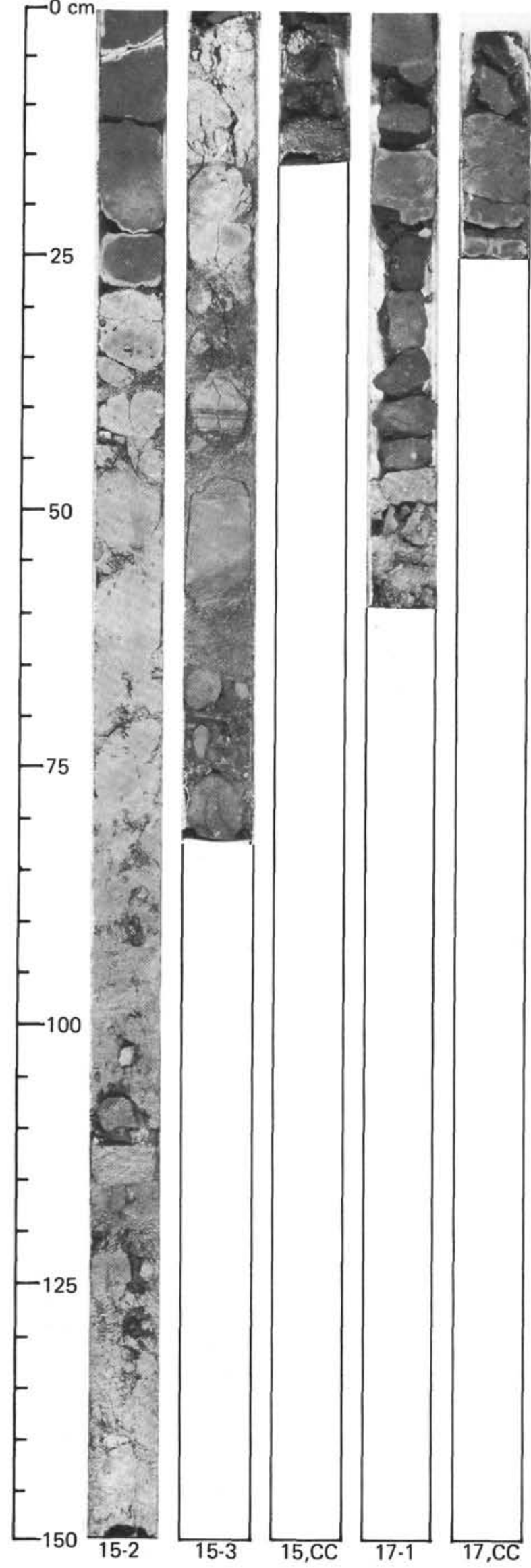

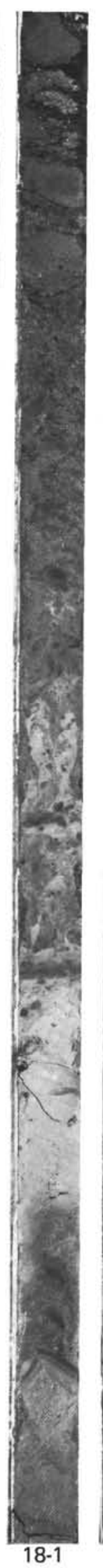
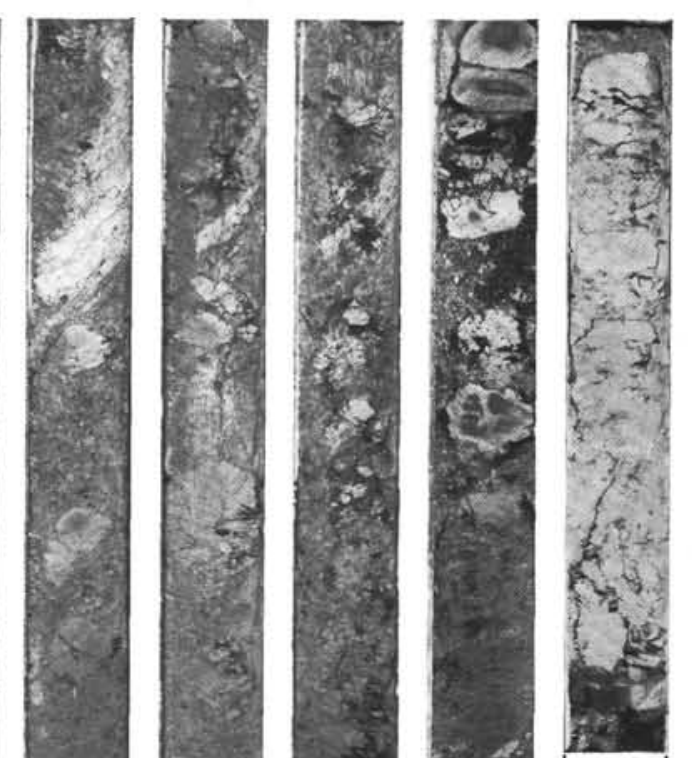

$$
\text { 1) }
$$

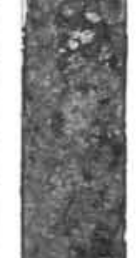

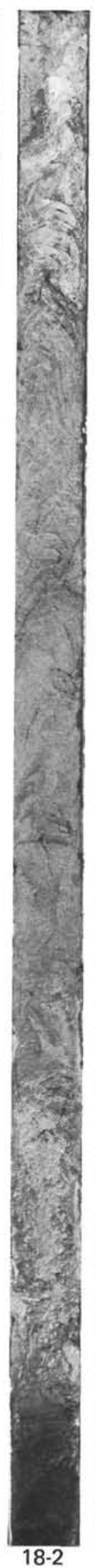

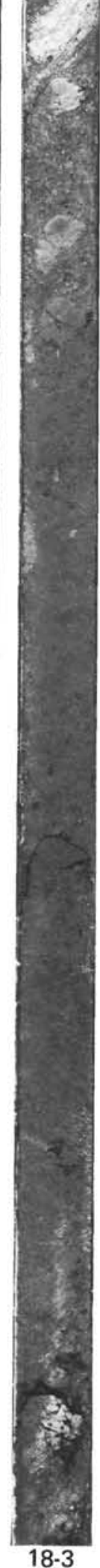

$$
\text { E. }
$$
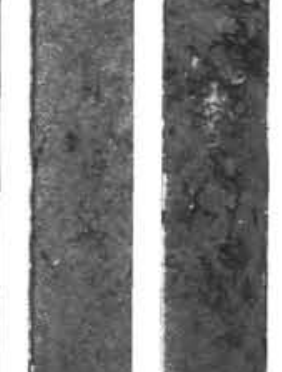


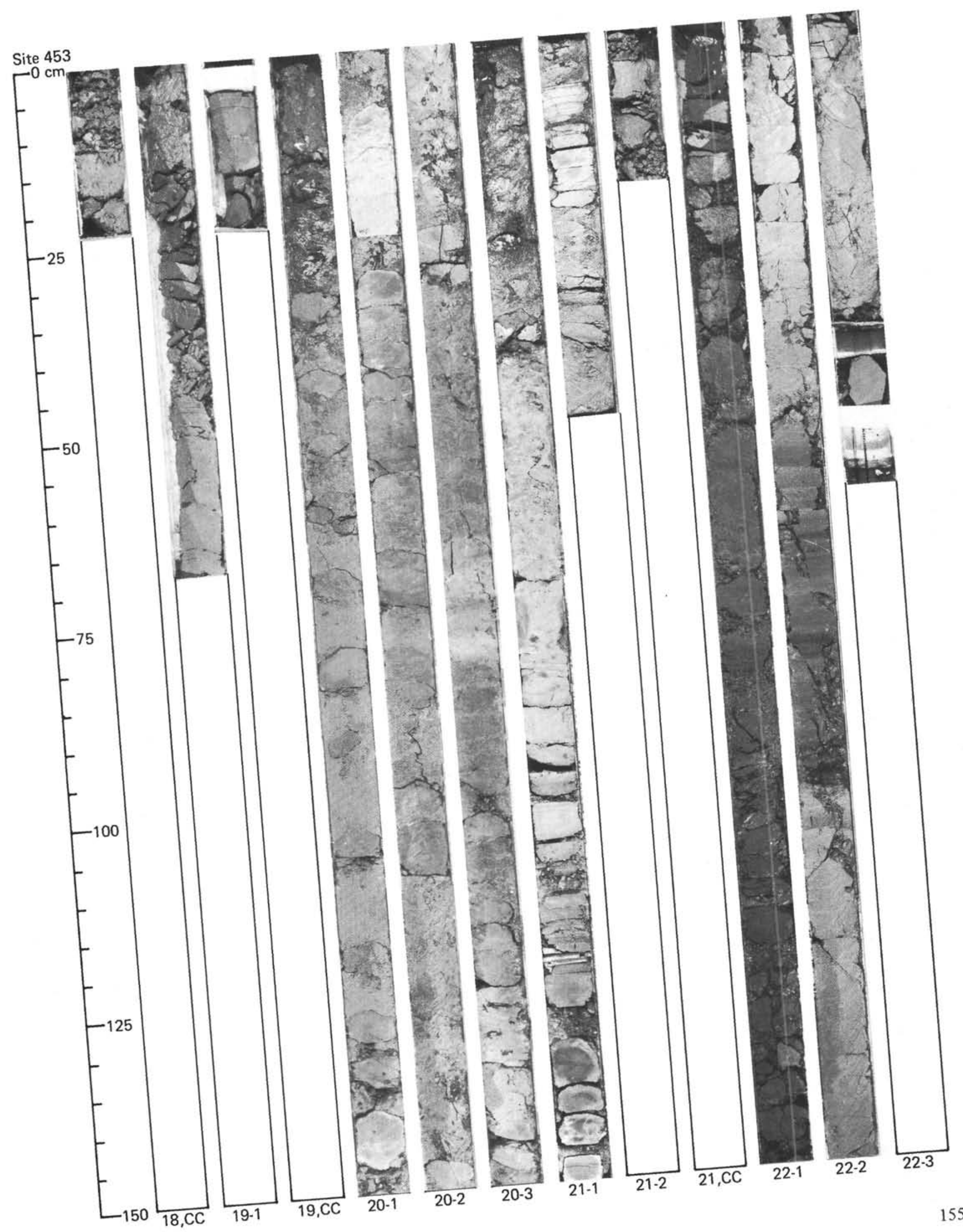




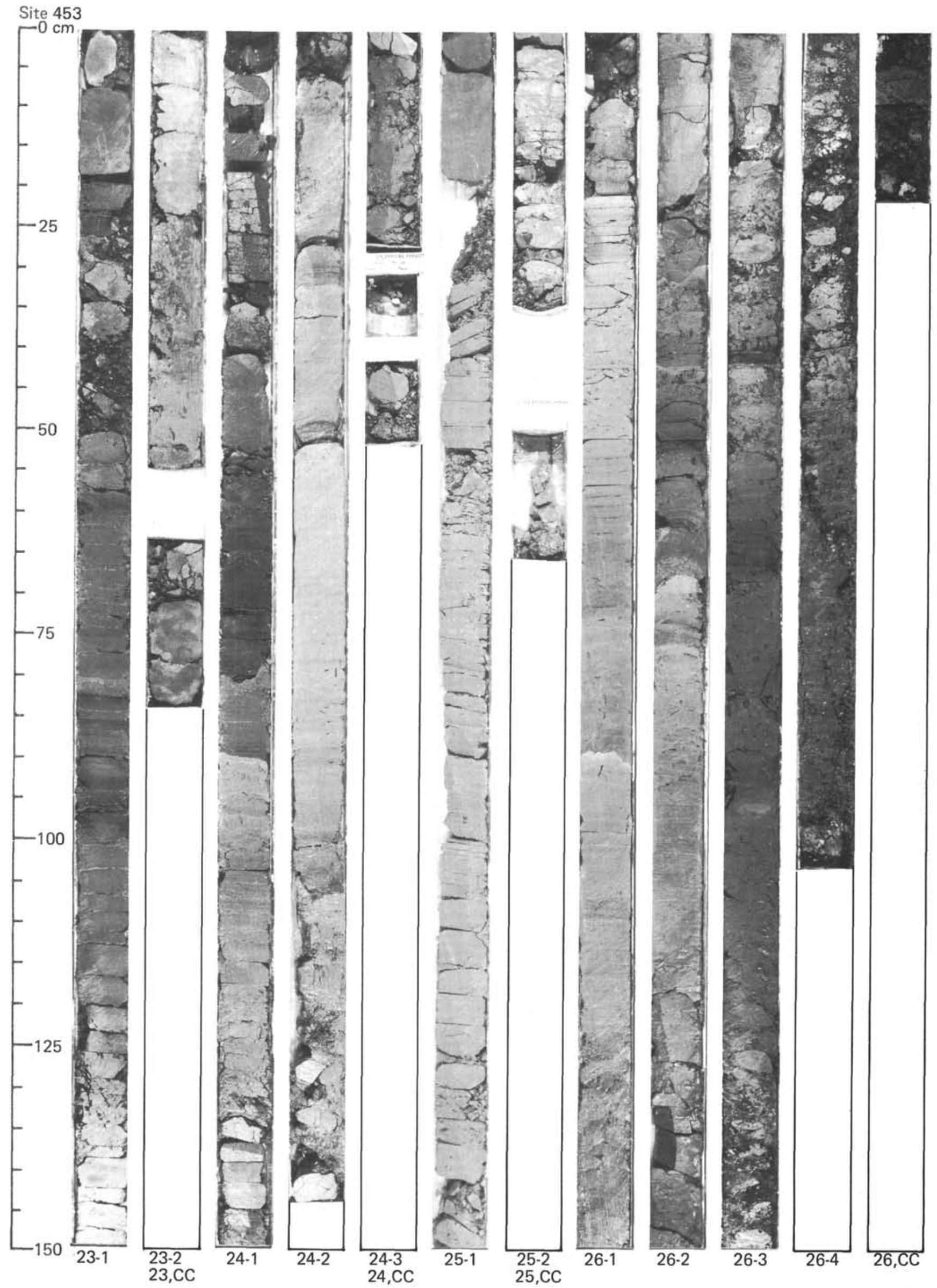


Site 453

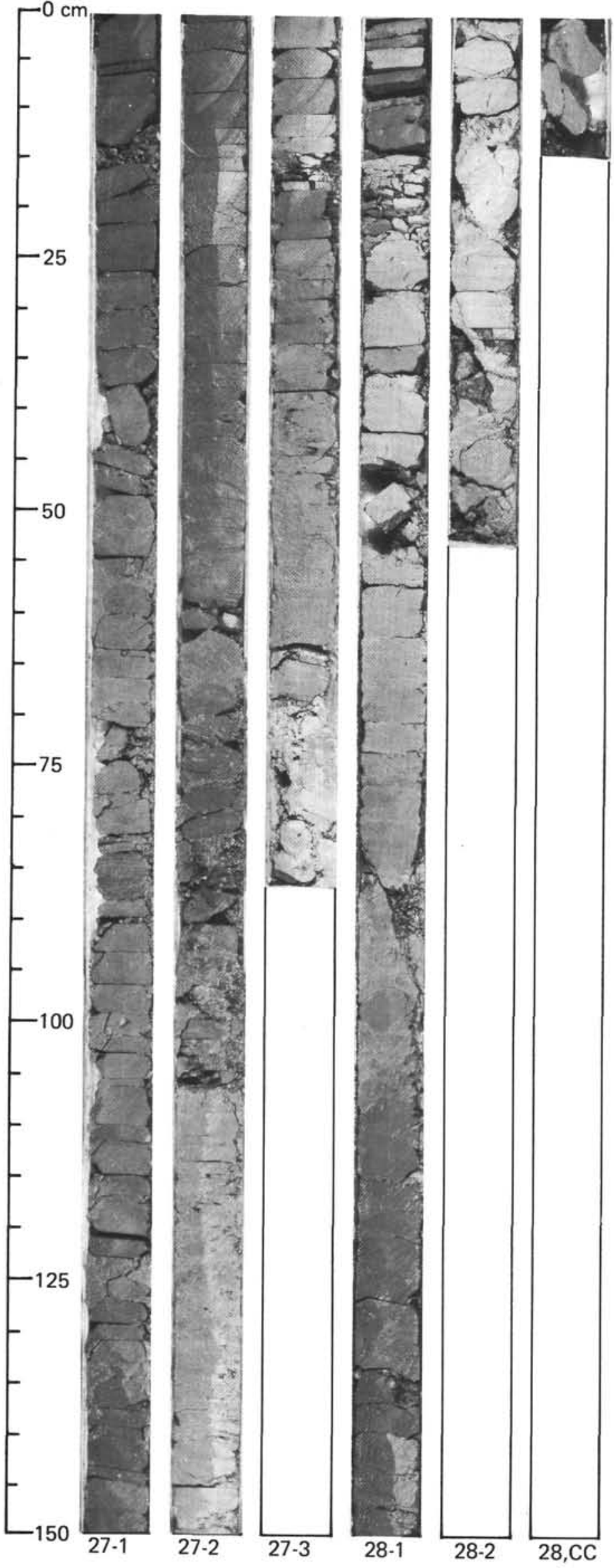

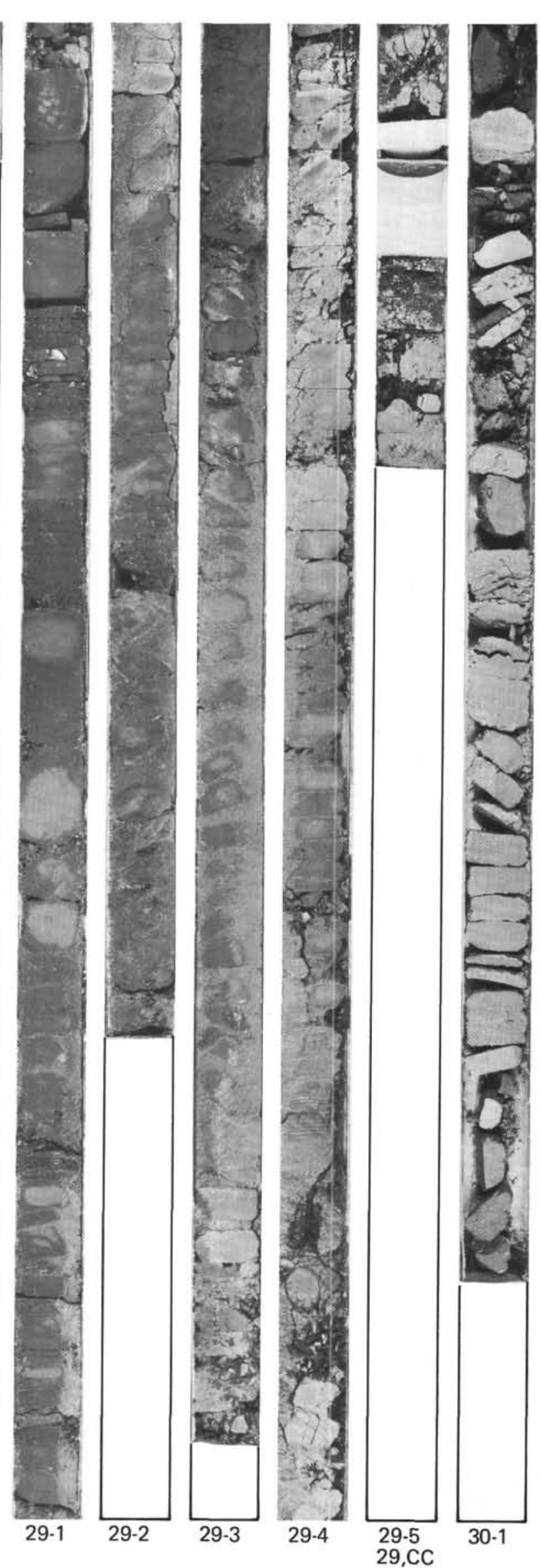



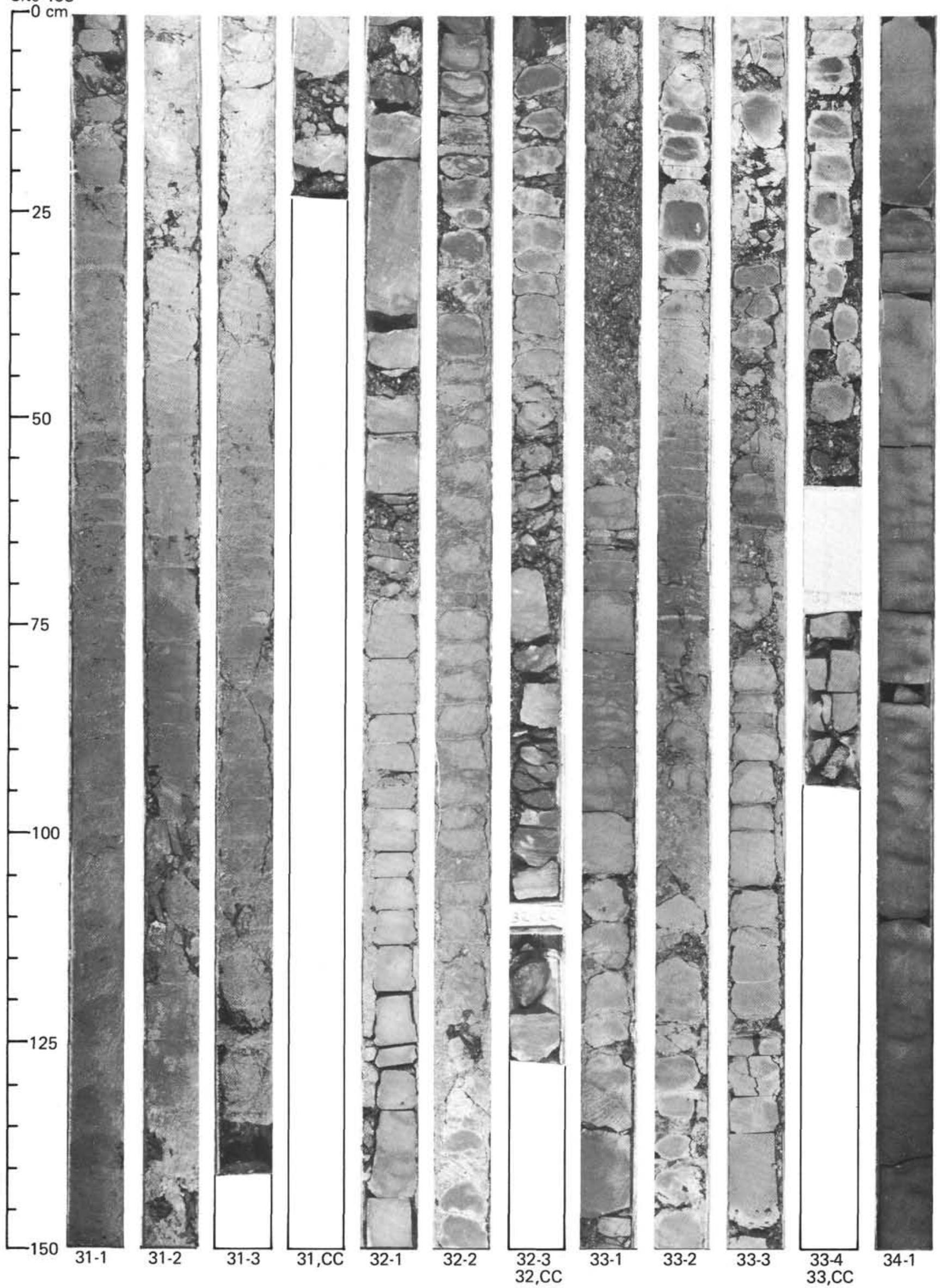
Site 453

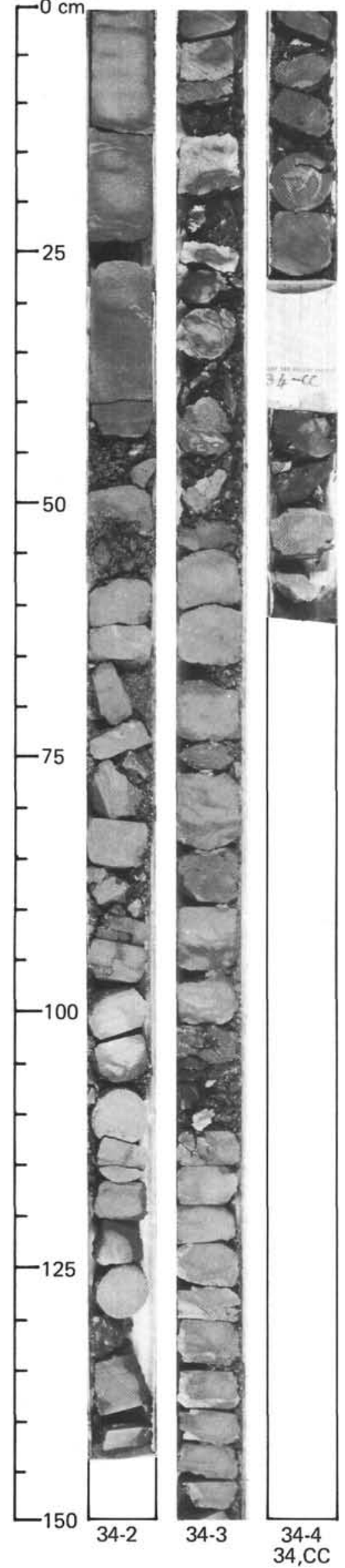

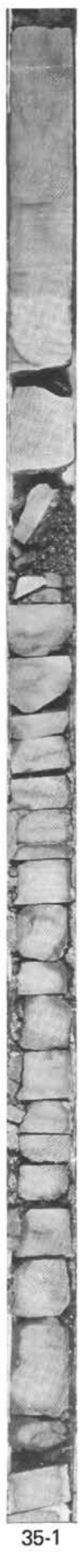
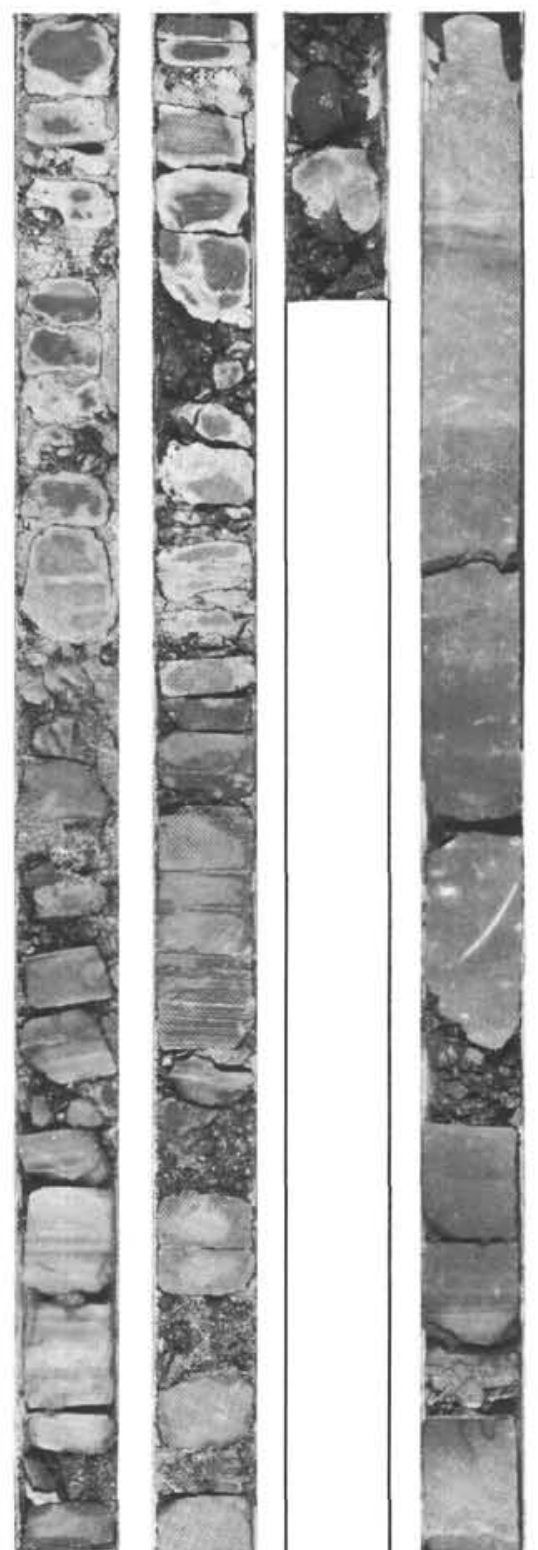

क्रा
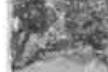

,
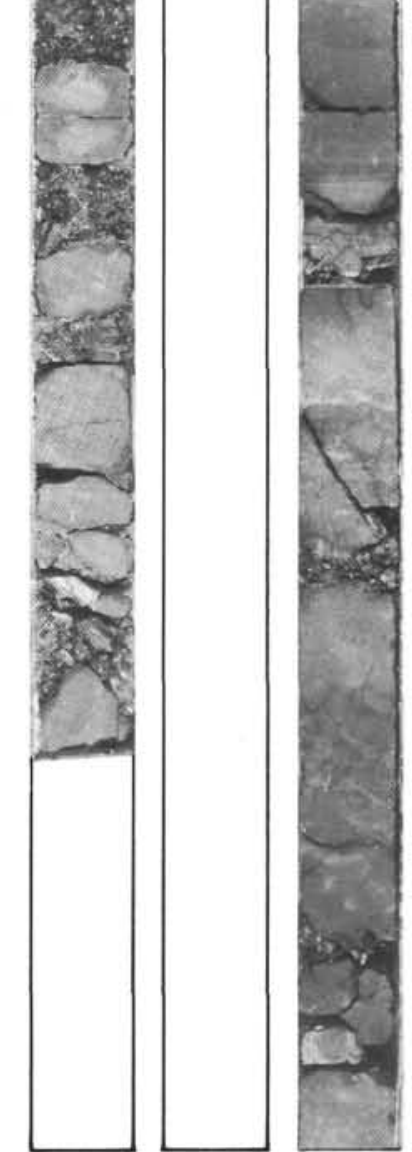

36-1
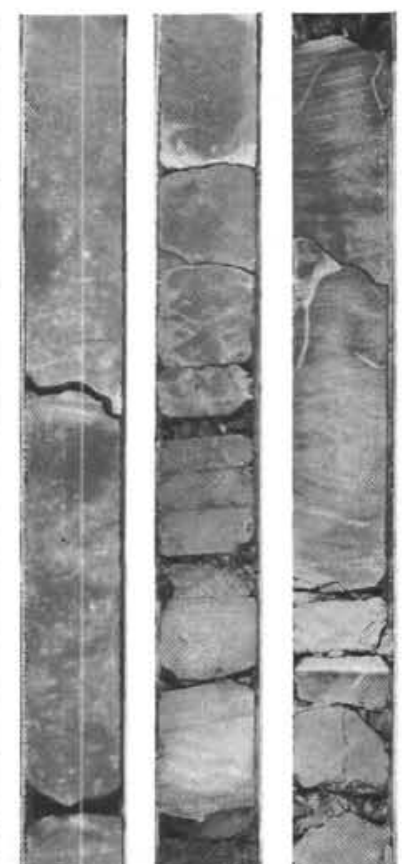

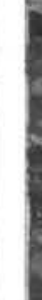
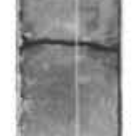

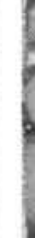
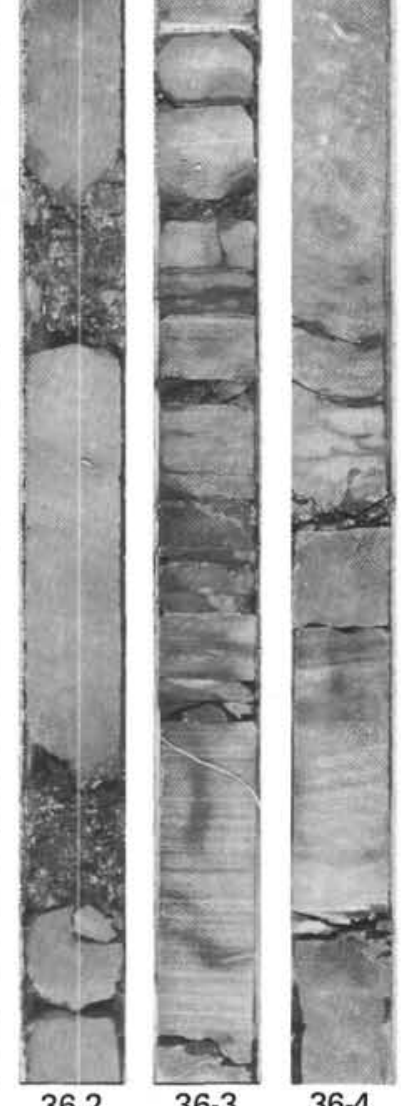

36-3
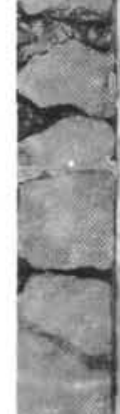
Site 453

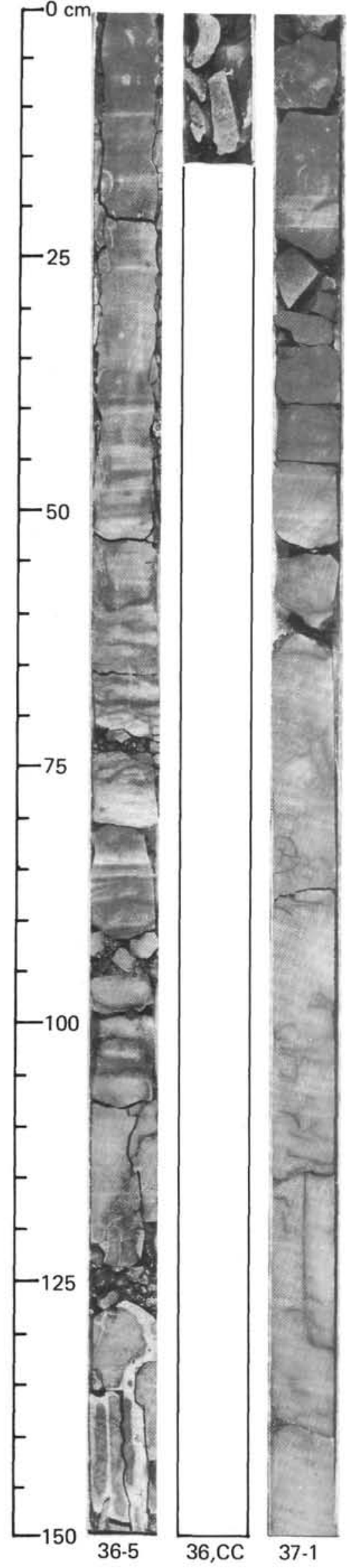

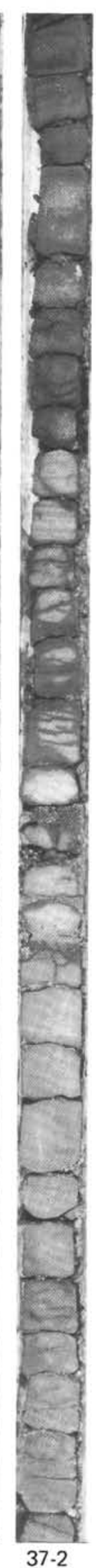
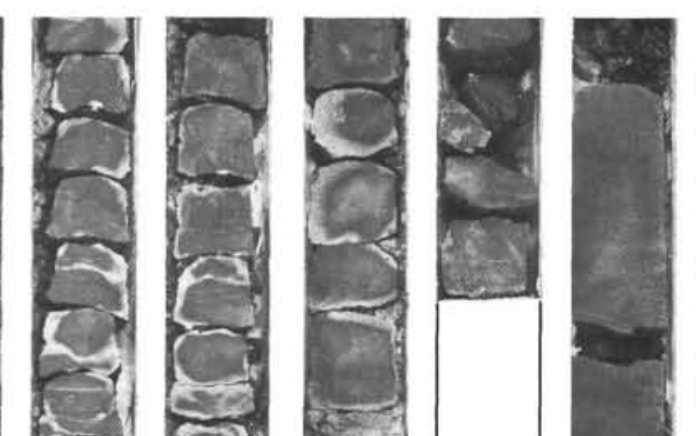

(2)

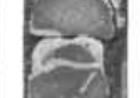

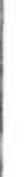
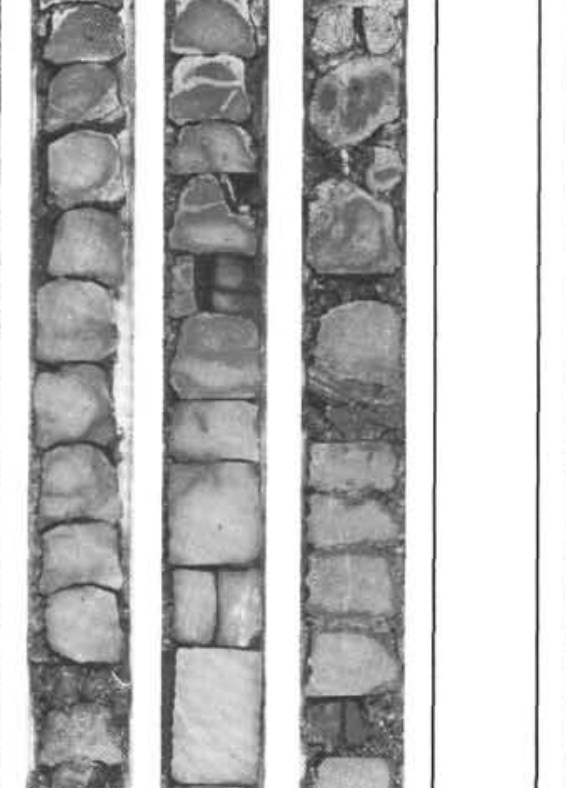

1
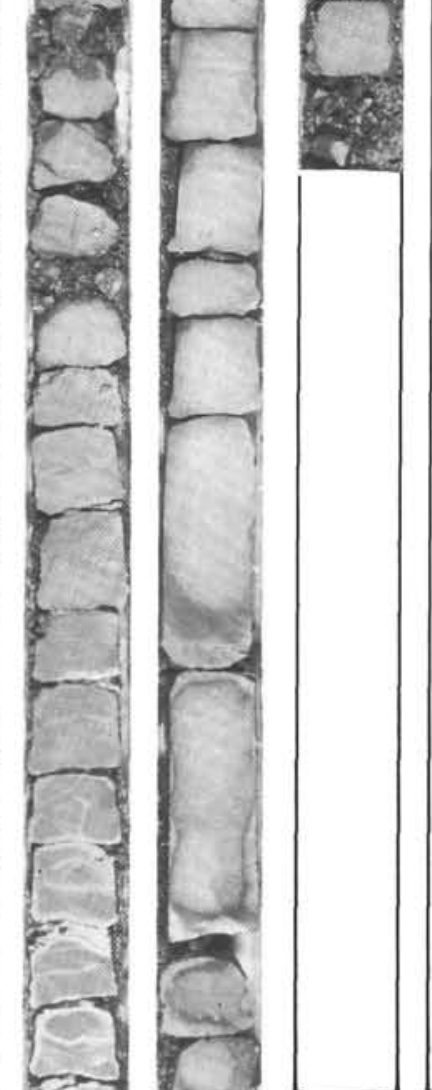

37-3

$37-4 \quad 37-5 \quad 37, \mathrm{CC}$
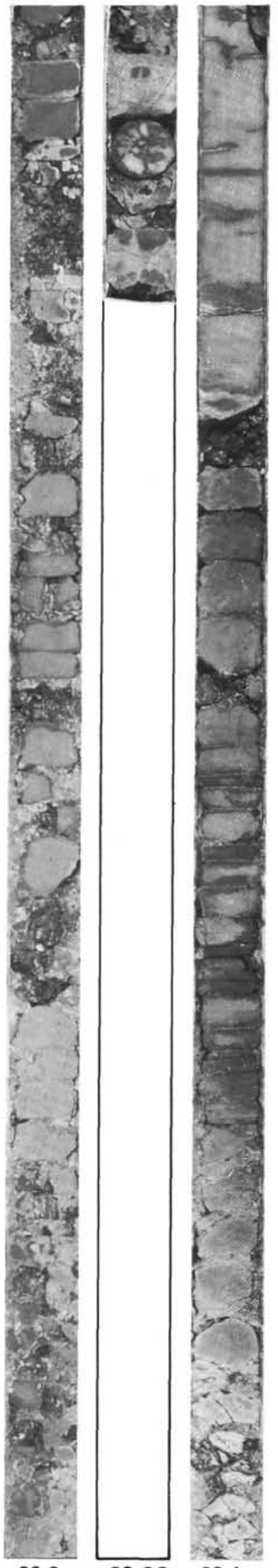

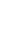

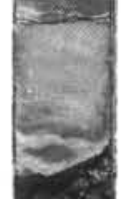$$
\text { b }
$$

cis

$$
\text { r. }
$$$$
\text { F }
$$$$
1
$$

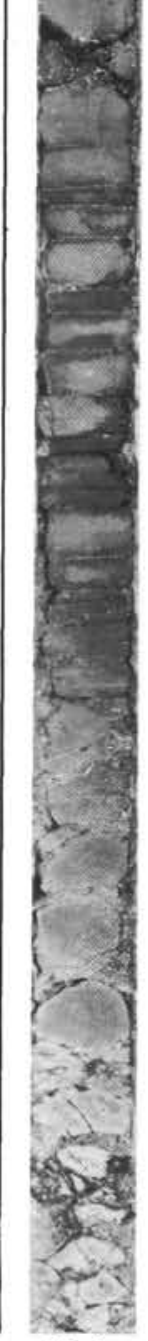

38-1 
Site 453

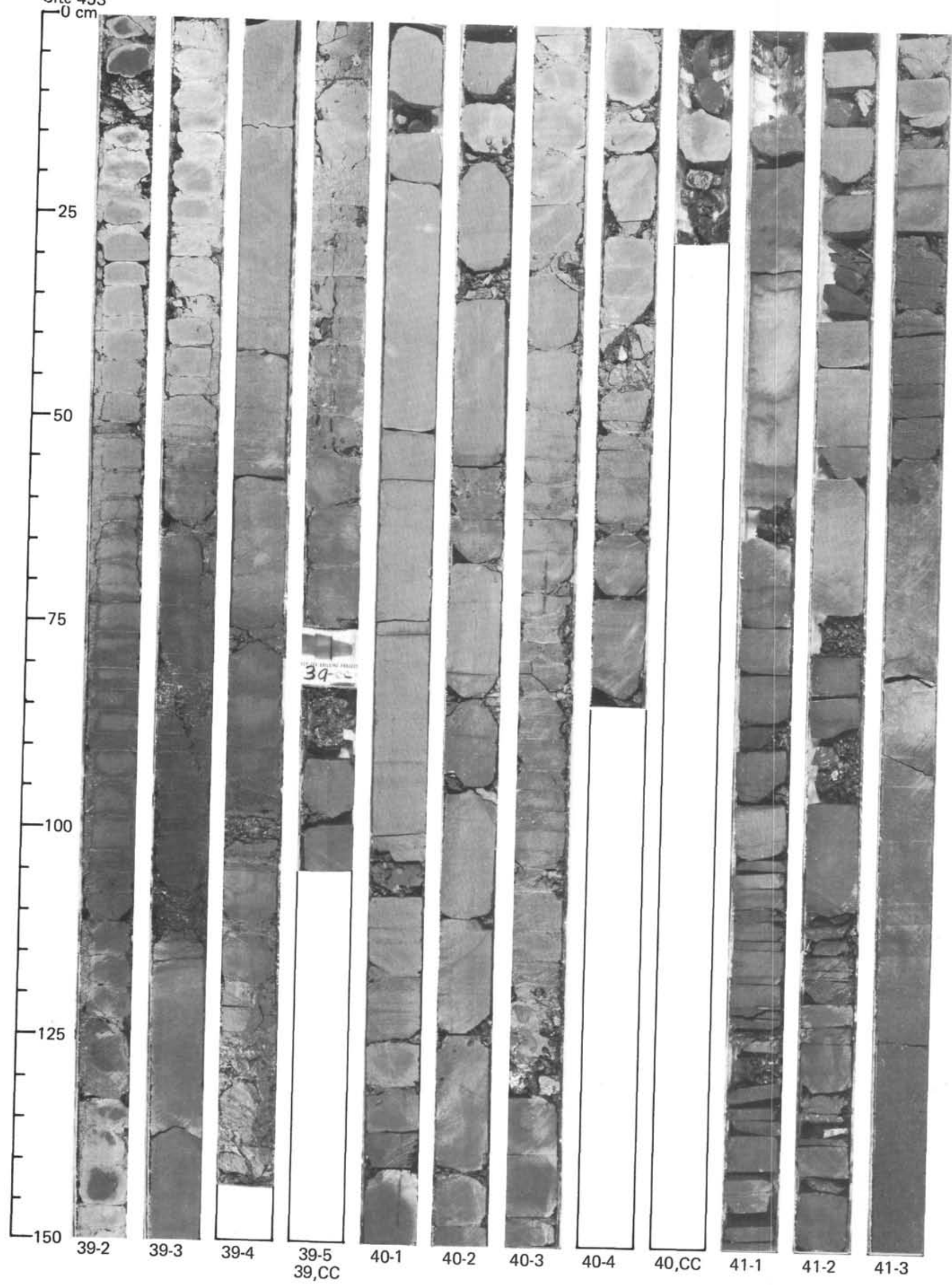


Site 453
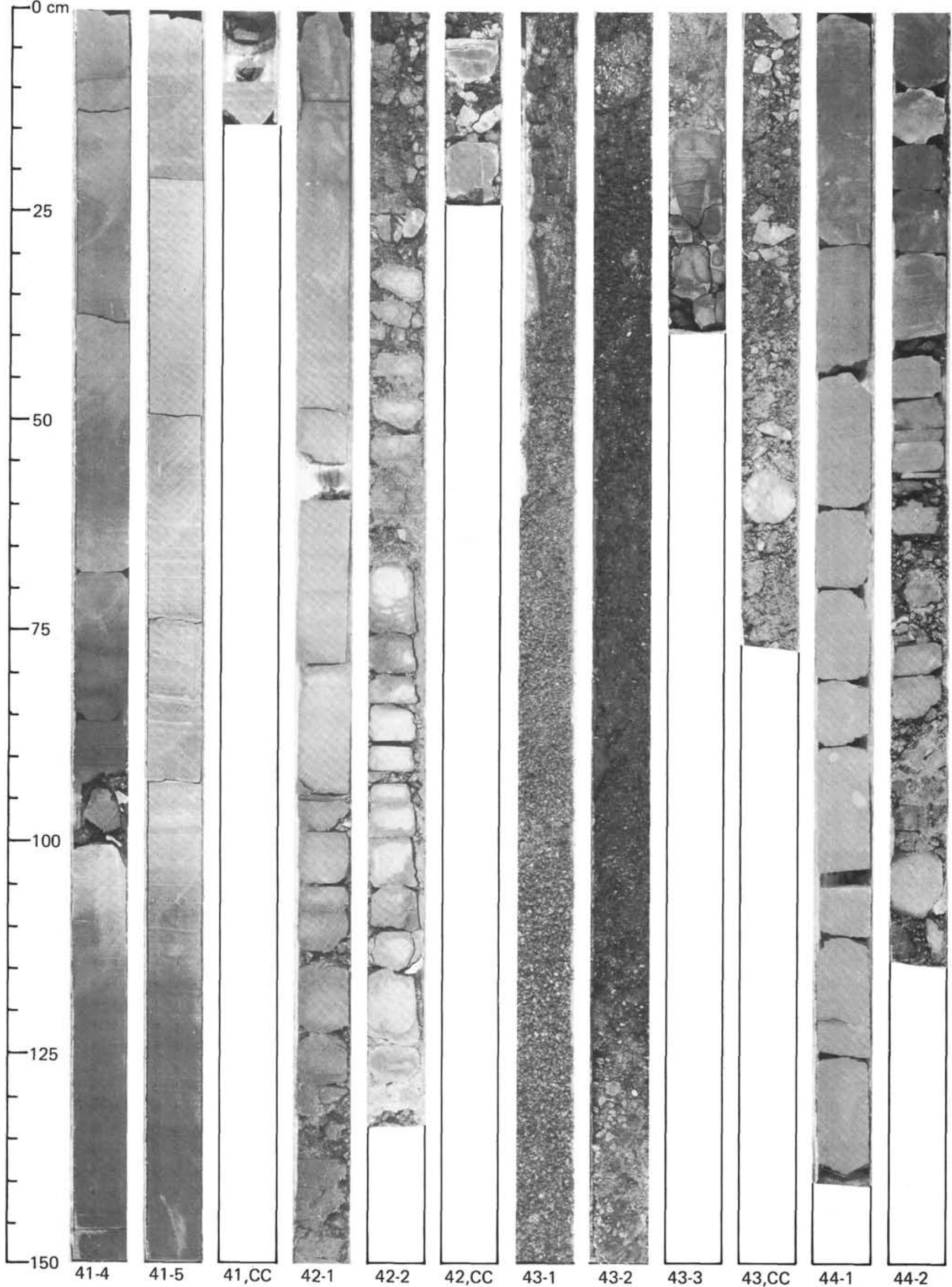

43-2

43-3 
Site 453

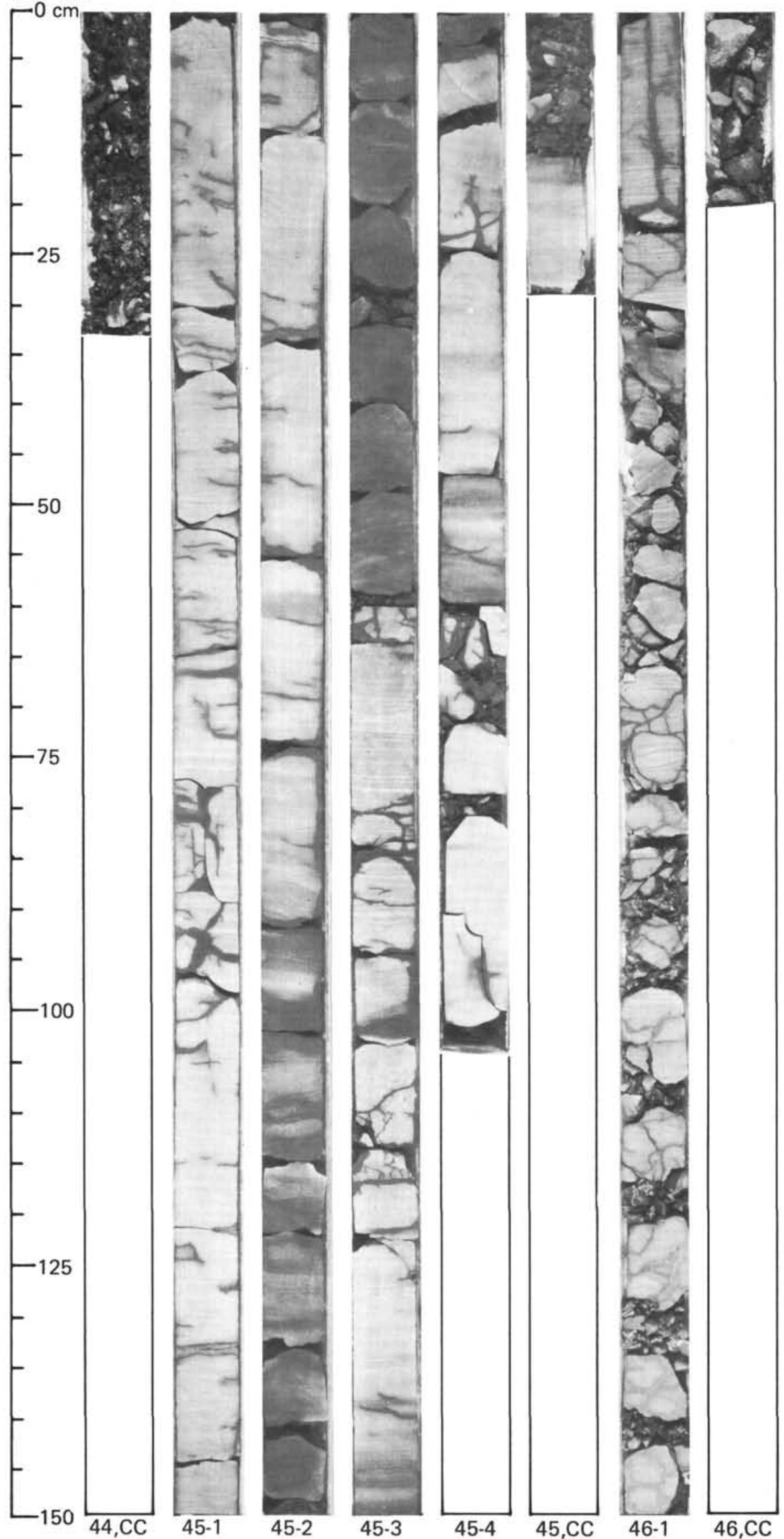

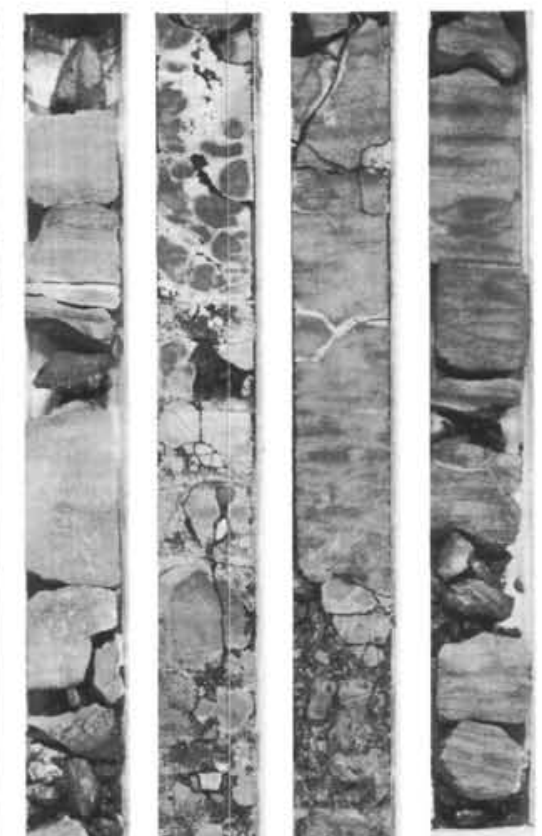
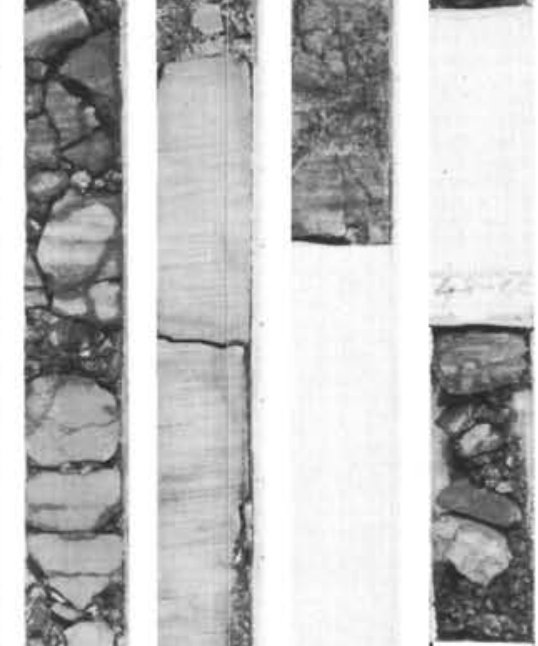

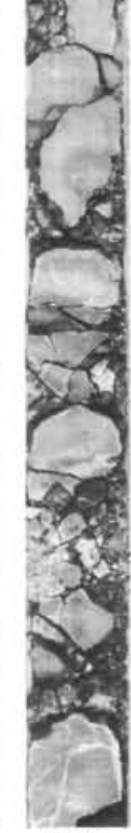

47-1
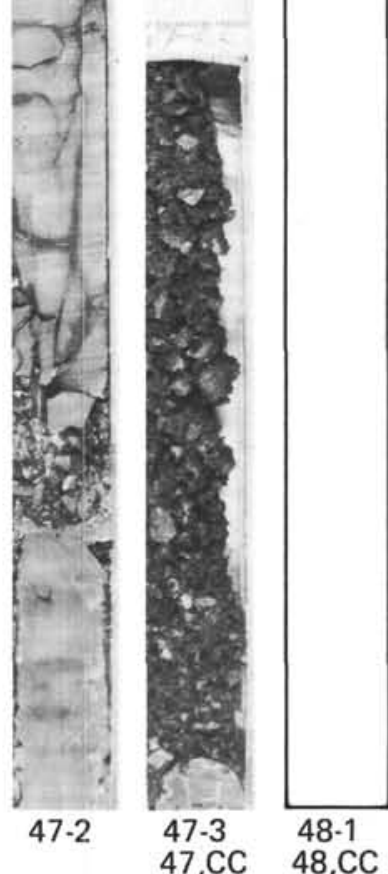


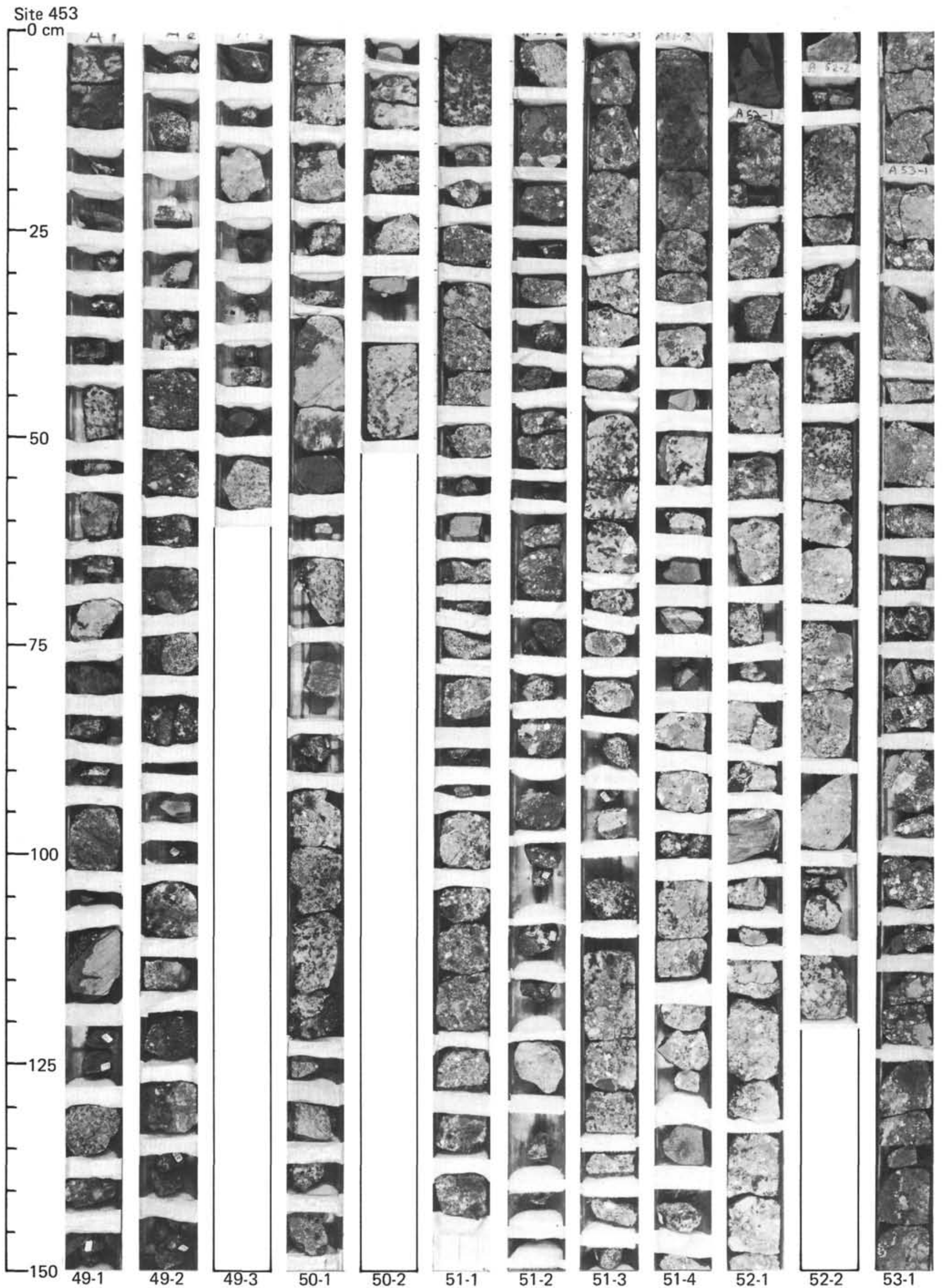


Site 453

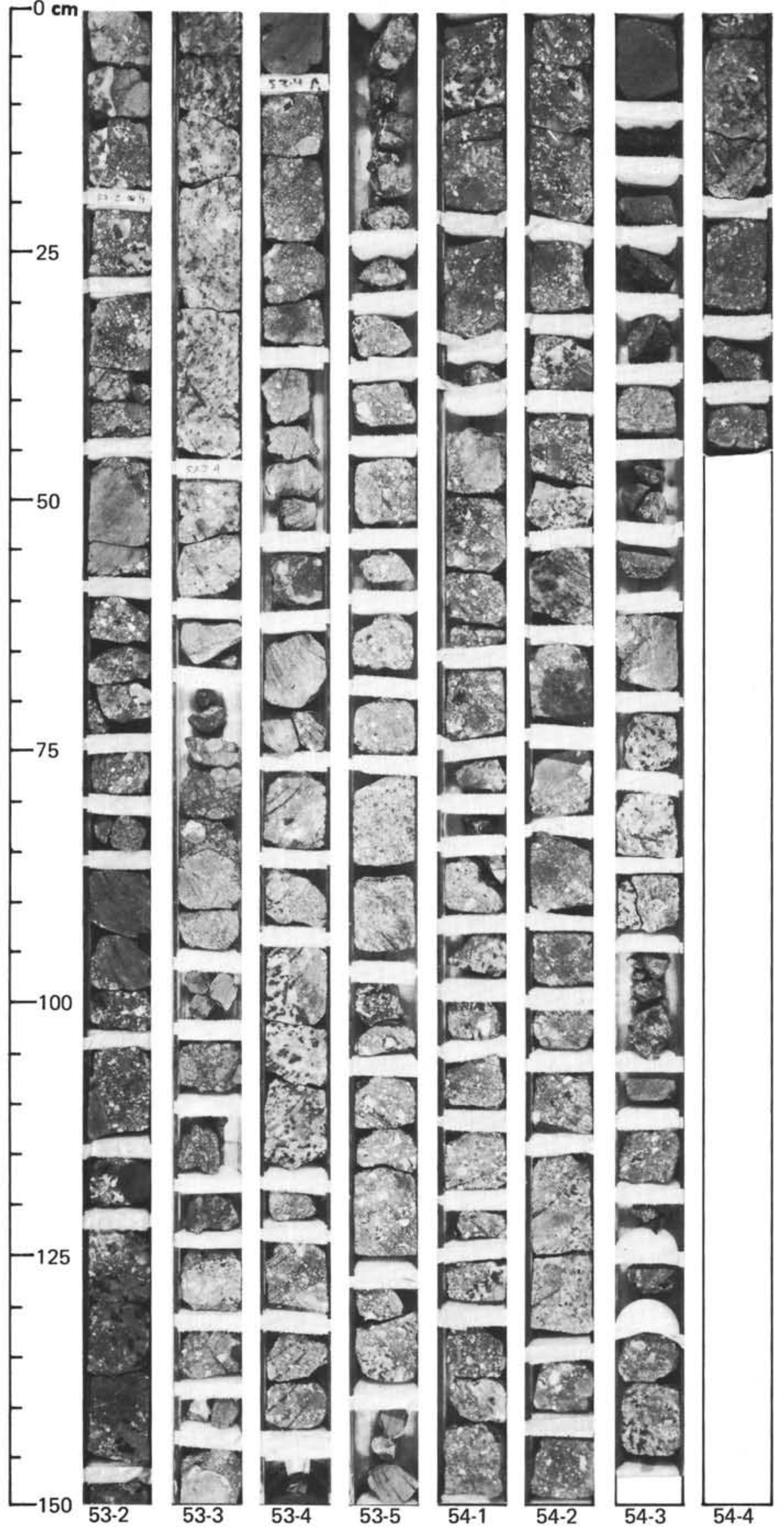

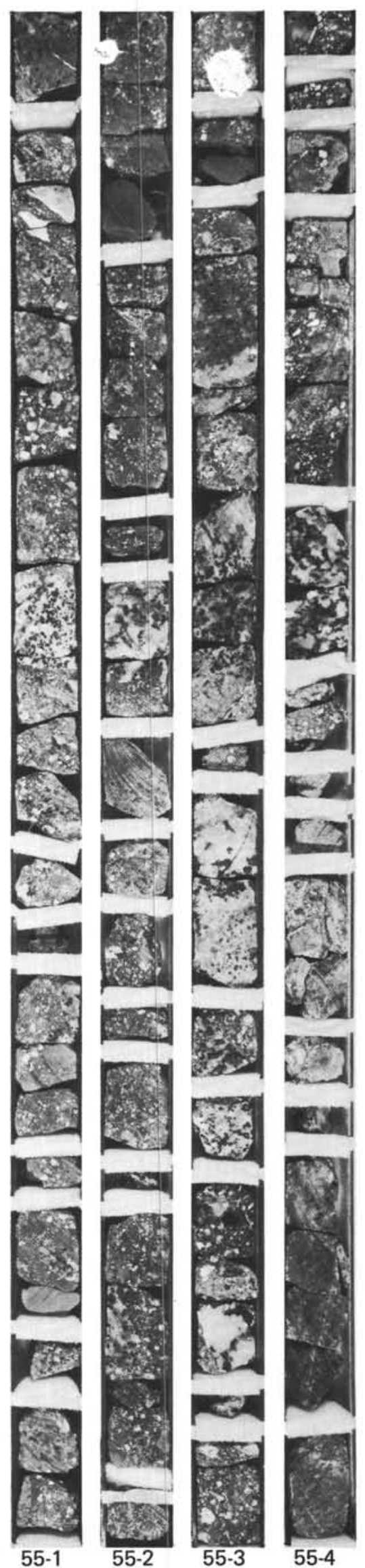


Site 453

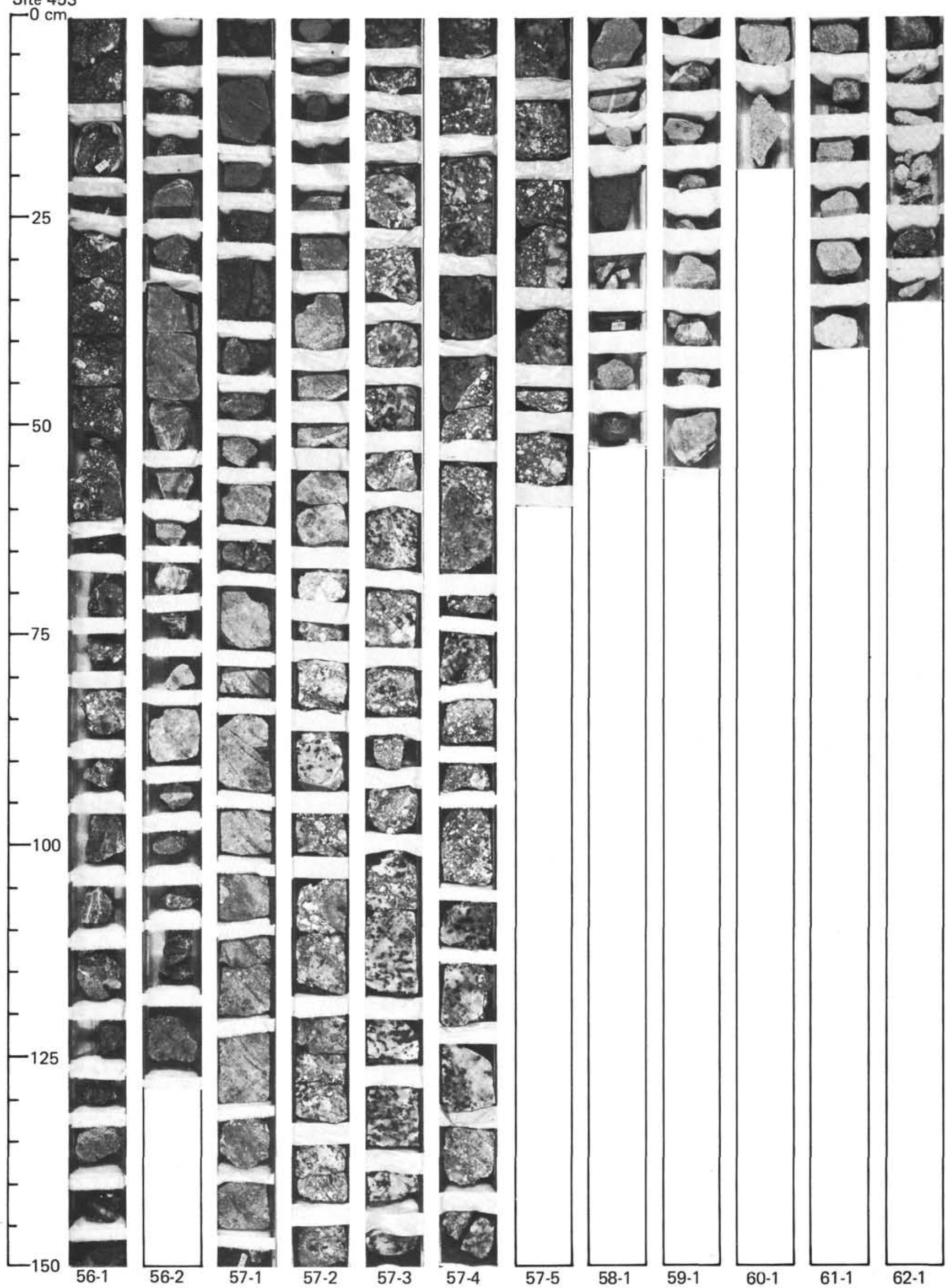


Site 453

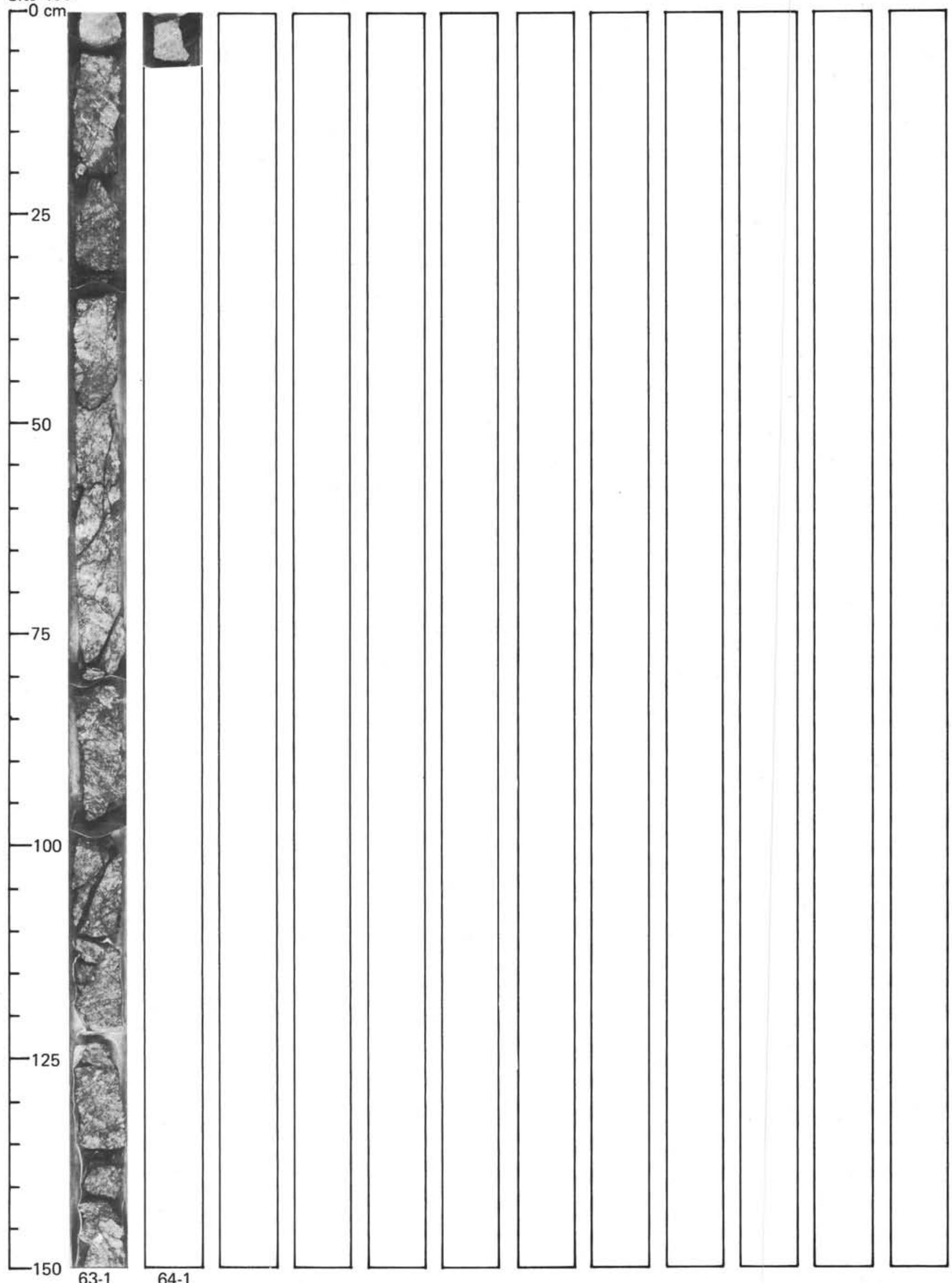

